\title{
Bacterial Cellulose Micro-Nano Fibres for Wound Healing Applications
}

\author{
Jubair Ahmed ${ }^{1}$, Merve Gultekinoglu² and Mohan Edirisinghe ${ }^{1 *}$.
}

${ }^{1}$ Department of Mechanical Engineering, University College London, London WC1E 7JE, UK.

2 Department of Basic Pharmaceutical Sciences, Faculty of Pharmacy, Hacettepe University, Ankara 06100, Turkey

*Corresponding author: m.edirisinghe@ucl.ac.uk

\begin{abstract}
Bacterial cellulose (BC) is cellulose produced by a few limited species of bacteria in given conditions. BC has many remarkable properties such as its high mechanical properties, water uptake ability and biocompatibility which makes it a very desirable material to be used for wound healing. Inherently due to these important properties, the material is very resistant to easy processing and thus difficult to produce into useful entities. Additionally, being rate limited by the dependency on bacterial production, high yield is difficult to obtain and thus secondary material processing is sought after. In this review, BC is explained in terms of synthesis, structure and properties. These beneficial properties are directly related to the material's great potential in wound healing where it has also been trialled commercially but ultimately failed due to processing issues. However, more recently there has been increased frequency in scientific work relating to $\mathrm{BC}$ processing into hybrid polymeric fibres using common laboratory fibre forming techniques such as electrospinning and pressurised gyration. This paper summarises current progress in BC fibre manufacturing, its downfalls and also gives a future perspective on how the landscape should change to allow $\mathrm{BC}$ to be utilised in wound care in the current environment.
\end{abstract}

Keywords: Bacterial Cellulose, wound healing, fibres, Gluconacetobacter xylinum, fibre production

\section{Introduction}

As early as in the $19^{\text {th }}$ century A.J Brown, noted that a specific bacterium produced a solid membrane at the surface of his culture when grown in a carbohydrate-rich medium (Brown, 1886). Later studies demonstrated that the material of the membrane produced by these bacterial species were identical to the principle structural polysaccharide of plants, cellulose (Hibbert, 1930). In contrast to plant cellulose, the gelatinous membrane showed incredibly high strength, purity, porosity, a uniform fibre network and enhanced water holding ability ( $R$. Chawla et al., 2009). The cellulose produced by the bacterial genera Gluconacetobacter (formerly Acetobacter) are commonly called bacterial cellulose (BC), which is in itself a biopolymer. Moreover, $\mathrm{BC}$ demonstrates the fascinating ability to enhance 
wound healing recovery, revealing the potential to revolutionise the healthcare market (Sulaeva et al., 2015). The cost of wound care for any healthcare provider marks a significant portion of overall expenditure. In hospitals, more than $30 \%$ of the beds are occupied by patients having wounds, some of whom who do not require to stay in the hospital for their main disorders (Posnett et al., 2009). With the rise in global average life expectancy, chronic wounds have shown strong correlation with increasing age (Gould et al., 2015).

There is a growing pressure for the development of advanced wound care that has capacity to meet the soaring demands. Although there is an abundance of literature on $\mathrm{BC}$ and its applications, there is little on the processing of $\mathrm{BC}$ into biomaterials for wound healing, especially in fibrous structures (Carvalho et al., 2019; Picheth et al., 2017; Thomas, 2008). This review focuses on the structure and properties of $\mathrm{BC}$, current progress on its processing for wound care applications and what is necessary to overcome in order to widely use this astonishing material in healthcare settings.

\section{Bacterial Cellulose (BC) Synthesis}

This cellulose is commonly referred to as "bacterial cellulose" or "microbial cellulose" which is found as a gelatinous membrane at the liquid-air interface of the culture medium (Kamide et al., 1990). BC is produced at certain culture conditions by a number of bacteria belonging to the genus: Achromobacter, Aerobacter, Agrobacterium, Alcaligenes, Azotobacter, Gluconacetobacter, Rhizobium and Salmonella (Rangaswamy et al., 2015). Yet, the gram negative Gluconacetobacter xylinum, has been primary focus in most BC related studies as the cellulose production is far greater in quantity and mass than the other strains, is of extraordinarily high purity and closely resembles that of algal and plant cellulose in its microfibrillar structure (Mikkelsen et al., 2014). Many strains of $G$. xylinum retain the ability to extracellularly produce cellulose in the form of flat, twisting ribbons. G. xylinum is an aerobic soil bacterium which belongs to a family of bacteria which are able to ferment carbohydrates into acetic acid (vinegar) (Peggy O'Neill and Cannon, 2000). 


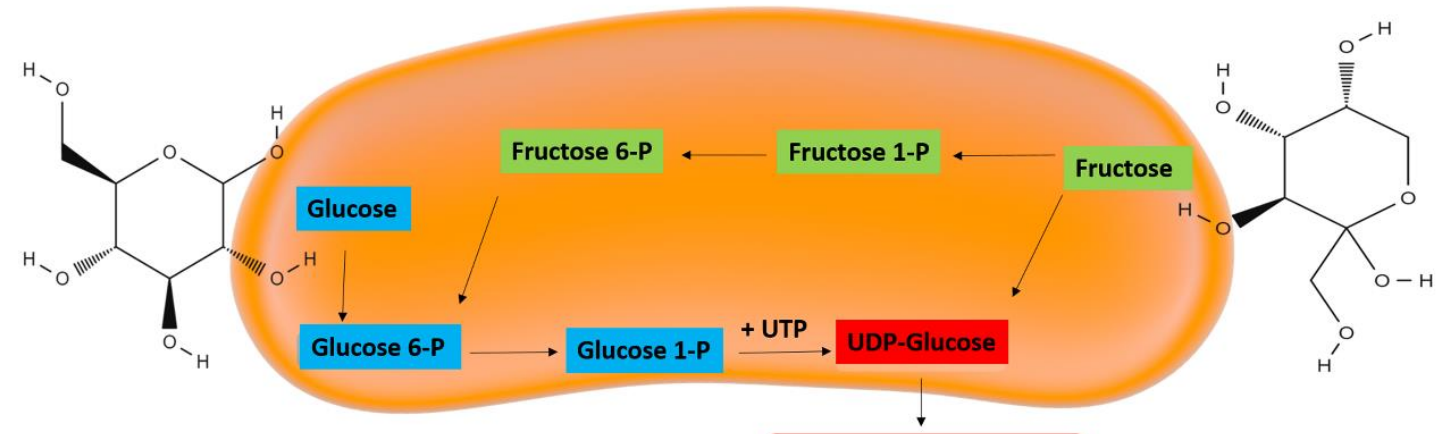

a)
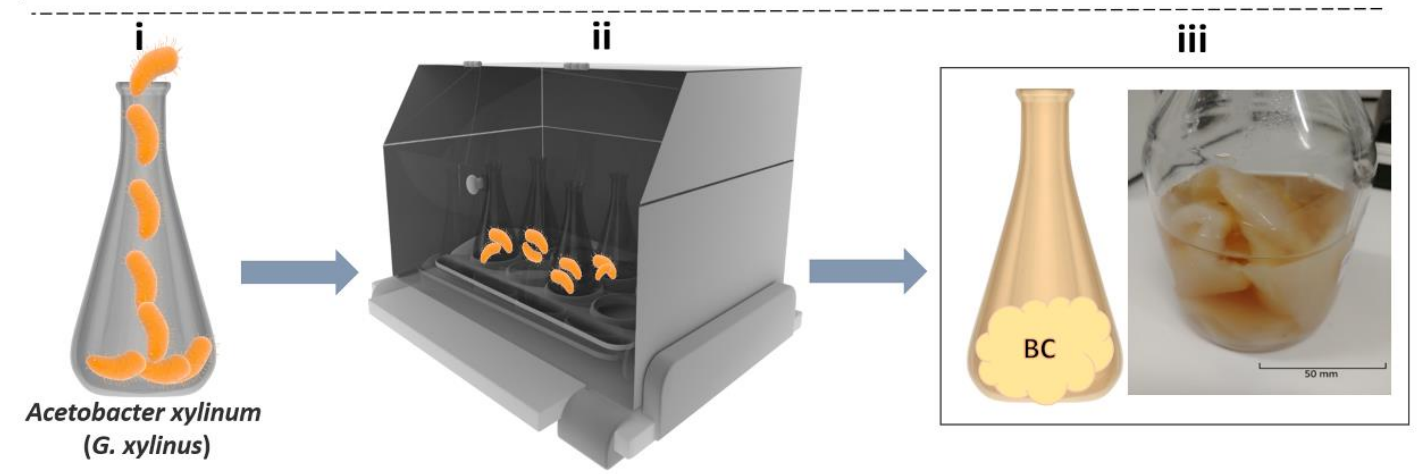

b)

Figure 1: Schematic diagrams of: a) BC fibrils synthesis reaction from glucose and fructose pathways. b) Schematic representation of BC synthesis (i) Acetobacter xylinum (G. xylinus), (ii) Acetobacter xylinum (G. xylinus) incubation, (iii) Photograph of bacterial cellulose (BC) gelatinous membrane encased within a 200 $\mathrm{mL}$ glass vial and suspended in acetic acid.

The synthesis of cellulose in $G$. xylinum occurs in a multi-step biochemical pathway of reactions beginning with glucose, which is catalysed by multiple enzymes. Cellulose synthesis is considered to be the most crucial enzyme in the BC production process and is responsible to the catalysis of the step preceding the final cellulose production (Ross et al., 1990). The commonly accepted pathway for cellulose production in G. xylinum cultures can be summarised as (Figure 1A): Glucose (catalysed by glucokinase) $\rightarrow$ Glucose-6-Phosphate (catalysed by phosphoglucomutase) $\rightarrow$ Glucose-1-Phosphate (catalysed by UDP-glucose pyrophosphorylase) $\rightarrow$ UDP-Glucose (catalysed by cellulose synthase) $\rightarrow$ Cellulose (Klemm et al., 2001).

A single cell of $G$. xylinum has been shown to be able to polymerise up to 200,000 glucose molecules per second into B-1,4-glucan chains (Hestrin and Schramm, 1954). These chains are extruded into the surrounding medium from the pole of the bacterial rod, which form a single ribbon-like bundle of microfibrils composed of single twisted strands (Ross et al., 1991). This ribbon elongates with the cell envelope at a rate of $2 \mu \mathrm{m}$ per minute and remains associated during cell division, at the liquid-air interface the suspensions continue with their microfibrillar projections for several hours, giving rise to a cellulosic pellicle (Brown et al., 1976). The fibrils of the ribbons are in close association with the pores longitudinally positioned in the bacterial cell membrane, cellulose biogenesis in G. xylinum is one of the best proven examples of unidirectional growth of cellulose microfibrils. 
(Zaar, 1979). A single cellulose fibril can be visualised as a cable where the lengthwise strands are D-glucose composed polymeric chains, each chain containing uniformly linked sugar monomers by $ß-1,4$ glycosidic bonds (Ross et al., 1991).

G. xylinum cultures are characterised as a thick glutinous cellulosic surface mat (Figure 2). This gelatinous membrane (pellicle) is where the embedded cells have direct contact with the liquid/air interface (Schramm and Hestrin, 1954). G. xylinum grows and forms cellulose in a range of carbon sources which include glucose, fructose and glycerol (Jonas and Farah, 1998; Mikkelsen et al., 2009; Weinhouse and Benziman, 1974). The growth, metabolism and cellulose production of this bacterium is free from cellulase activity which would otherwise break down the cellulose, this provides a distinct advantage over plant cellulose by being metabolically inert and highly pure (Vandamme et al., 1998).

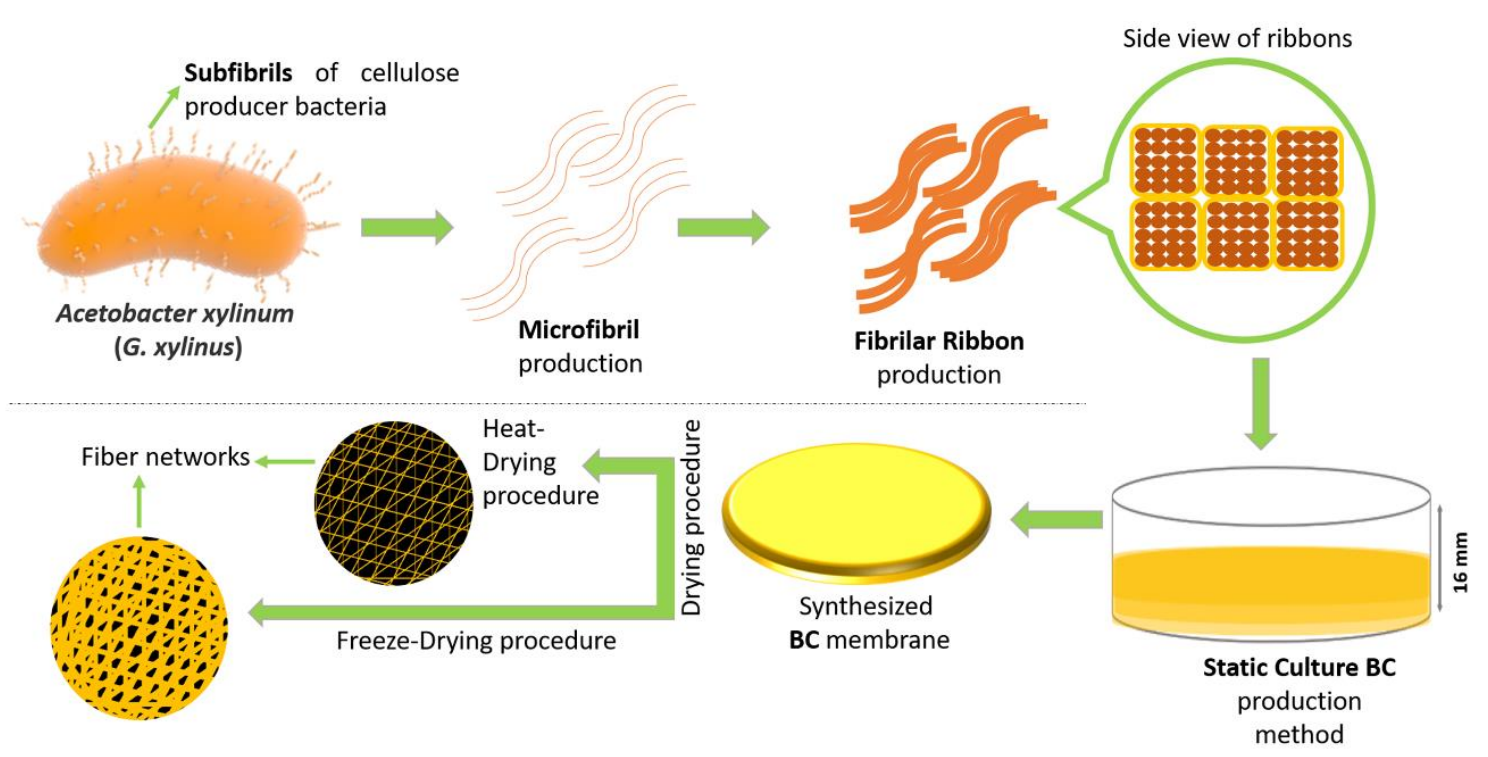

Figure 2: Diagrammatic representation of $B C$ from microfibrils to fibre networks production, step by step in static conditions. Side view depiction of a thick BC gelatinous membrane mat which assumes shape of environment, shown here on a petri dish. The mat contains highly pure network of $B C$ nanofibrils.

Several techniques exist for $\mathrm{BC}$ production that demonstrate different degrees of potential for economical and commercially viability as a BC fabrication method. The selection of the cultivation method stringently determines the cellulose microstructure and thus its mechanical and physical properties. Static culture methods (Figure 2) employ stationary culture in plastic trays or dishes and have shown to produce a thick and gelatinous BC membrane on the surface of the culture medium which compares with most BC produced and tested (Budhiono et al., 1999; Dudman, 1960). The BC pellicle in a static culture is visible at the surface of the liquid about 2 days from the beginning of the process (Schramm and Hestrin, 1954). An alternative approach to BC cultivation is incorporating an agitated culture such as jar fermenters, horizontal fermenters or internal loop airlift reactors (Kouda et al., 1997; Kouda et al., 1996). Agitated culture approaches can produce cellulose in fibrous suspension forms, pellets, spheres or irregular 
masses (Figure 1B) (Chao et al., 2000; Naritomi et al., 1998a; Tsuchida and Yoshinaga, 1997).

Static culture systems have been widely investigated and their applications have seen successful commercial applications such as in food and in electronics (Bernardo et al., 1998; Yamanaka et al., 1989). Nevertheless, agitated culture methods are usually deemed more suitable for large scale production due to their higher potential production rates when considering total area of cultivation required. There are, however, many problems that are encountered with cellulose production in fermenters that utilise continuous aeration and agitation. The sporadic presence of non-cellulose producing mutants $\left(\mathrm{Ce}^{-}\right)$, leads to the decline in biopolymer production in agitated cultures (Jung et al., 2005; Ross et al., 1991). These mutants are a result of the inactivation of the gene coding for cellulose synthesis (Krystynowicz et al., 2002). In static conditions, cellulose-synthesising Gluconacetobacter cells $\left(\mathrm{Cel}^{+}\right)$migrate towards the oxygen-rich medium air interface, where they produce the gelatinous membrane. The membrane limits access to oxygen into the lower depths of the culture and majority of the cells are found in the $\mathrm{Cel}^{+}$form. In agitated systems, the uniform aeration leads to preferential growth of bacterial cells instead of cellulose synthesis, in this case the culture is dominated with Cel mutants (Krystynowicz et al., 2002). Furthermore, it was shown that static cultures of $G$. xylinum actually leads to higher yield levels than with swirled cultures, at a period of 2 days following incubation yield was 1.8 $x$ higher in static cultures than with agitated and after 5 days yield was $2.8 x$ higher in static conditions (Schramm and Hestrin, 1954). Static systems can be less favourable for scale up operations due to the amount of free space required and could limit productivity rate.

Culture conditions can have a marked effect on cellulose production for many different strains of bacteria capable of producing BC (Rangaswamy et al., 2015). Factors such as inoculum density influence the microbial cellulose production, where increasing the concentration of the substance can lead to a reduction in yield, therefore there is an optimum density which needs to be considered. Additionally, there exists an ideal $\mathrm{pH}$ range in which both cell growth and cellulose production is the greatest. In tested conditions from $\mathrm{pH} 3-7$, it was found that a $\mathrm{pH}$ of 6 led to maximum yield compared to the other $\mathrm{pH}$ values (Rangaswamy et al., 2015). Temperature furthermore effects cellulose production where favourable culture temperatures are around $28-30^{\circ} \mathrm{C}$ and when temperatures exceed $40{ }^{\circ} \mathrm{C}$, $\mathrm{BC}$ production was not observed. Carbon is the sole source of $\mathrm{BC}$ production and thus has a significant influence on the yield of BC and its final morphology. Carbon sources such as fructose, glucose, lactose, maltose, mannitol, mannose and sucrose can be utilised to produce BC from different bacteria, maximum yields are usually observed with using sucrose as the carbon source (Eslahi et al., 2020; Wang et al., 2019). Nitrogen is another essential component in cell growth and cellulose production for many bacterial strains, examples of nitrogen sources are: ammonium chloride, ammonium nitrate, ammonium sulphate and peptone. Optimal BC preparation for certain bacteria can result from the use of peptone as the source of nitrogen. On the other hand, cellulose formation from G. xylinum and glucose has been observed to be limited by the oxygen concentration of the culture, where negligible BC was produced with nitrogen and maximal amounts where produced with 100\% oxygen (Schramm and Hestrin, 1954). 


\section{Structure of Bacterial Cellulose}

Similar to that of plant cellulose, BC shares the same molecular formula $\left(\mathrm{C}_{6} \mathrm{H}_{10} \mathrm{O}_{5}\right)_{n}$. The exopolysaccharide-produced $B C$ differs from conventional cellulose in its physical and chemical features. The two cellulose types bear the same chemical similarity being B-1,4-glucans, but differ in their degree of polymerisation (Yoshinaga et al., 1997). The degree of polymerisation for BC is considerably lower, having a typical polymerisation range between 2000-6000 compared to $13000-140000$ of plant cellulose.

$B C$ is composed of twisted ribbon-shaped fibrils approximately $50-100 \mathrm{~nm}$ in width and 3-8 nm in thickness (Astley et al., 2001; Brown et al., 1976; Yamanaka and Sugiyama, 2000; Zaar, 1977). It has been shown by X-ray diffraction (XRD), that the size of the microfibrils are associated with its crystallite size (Haase et al., 1974). These ultrafine ribbons have a length of 1-9 $\mu \mathrm{m}$ and form a densely arranged structure stabilised by comprehensive inter-and intra-hydrogen bonding (Bielecki et al., 2005; Esa et al., 2014). The average distance between junction points (pore size) of a typical BC membrane has been calculated to be $0.523 \pm$ $0.273 \mu \mathrm{m}$, and the orientation of the segments as the average angle formed between the $x$-axis and the segments is $85.64 \pm 0.56^{\circ}$ ( $\mathrm{J}$ Grande et al., 2008).

The macroscopic structure and morphology of $\mathrm{BC}$ fibres are strictly dependant on the cultivation techniques used to produce them (Watanabe et al., 1998). In a static culture, the bacterial cells produce cellulose mats at the surface of the nutrient broth where the interface between the liquid and the oxygen rich air exists. In these conditions, G. xylinum cells continuously extrude subfibrils of cellulose from their surface pores which in turn become crystallised into microfibrils, and are forced down deeper through the growth medium (Bielecki et al., 2005). As a result, the cellulose produced in static conditions result in leather-like pellicles which support the population of G. xylinum cells. These pellicles consist of overlapping and intertwined cellulose ribbons which form a grid of parallel but disorganised planes (Jonas and Farah, 1998). Comparatively with cellulose produced in agitated cultures, the adjacent strands of the cellulose mats branch and interconnect to a higher degree prevalent in static cultures. In agitated conditions, the increased branching is observable in the form of fibrous strands and irregular granules dispersed thoroughly through the culture broth (Vandamme et al., 1998). Furthermore, the agitated BC interconnect to form a grid-like pattern (Watanabe et al., 1998). The differences in morphology between cellulose produced by agitated and static conditions also contribute to differing levels of crystallinity,

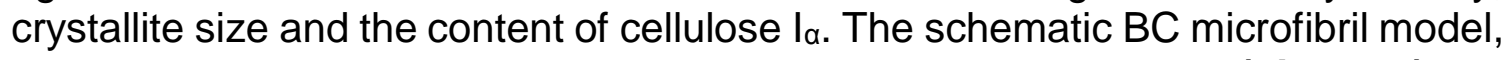
physical properties and biomedical application areas are shown in (Figure 3). 


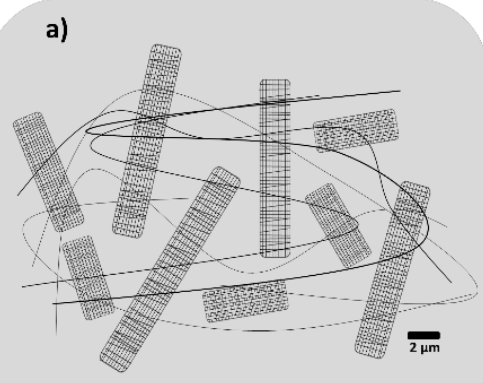

b)

Bacterial Cellulose: Physical Properties

- High porosity

- High mechanical strength

- Biocompatibility

- Permeability

- Biodegradability

- Transparency

- Flexibility

- Hydrophilicity

\section{c)}

Bacterial Cellulose: Biomedical

Applications

Skin (wound dressing)

- Cartlidge

- Cornea

$\square$ Bone

- Urethra

Blood vessels

- Contact lenses

- Drug delivery systems

- Bio sensors

Figure 3: a) Schematic diagram of $B C$ microfibrils, showing a unique structure that isn't commonly found in cellulose, b) Physical properties of BC (Hussain et al., 2019), c) Biomedical applications of BC (Gallegos et al., 2016; Portela et al., 2019).

Further differences between agitation produced $\mathrm{BC}$ and statically produced $\mathrm{BC}$ are obvious when viewed using a Scanning Electron Microscope (SEM). Statically produced $\mathrm{BC}$ have fibrils with a more extended morphology with fibrils stacked above one another in a crisscross pattern. Conversely, strands of agitation produced BC reveal an entangled and curved physiology (Johnson et al., 1989). Compared to plant cellulose, BC has a unique characteristic in its crystalline structure. Native cellulose consists of cellulose $\mid \alpha$ and cellulose $\mid \beta$ crystalline structures, where cellulose $I \beta$ is the major component, approaching approximately $60 \%$ in composition. (VanderHart and Atalla, 1984; Yamamoto and Horii, 1993). Interestingly however, BC contains $60 \%$ cellulose la (Atalla and Vanderhart, 1984).

Another key difference between plant cellulose and BC lies in their morphological structures. In plant cellulose, several cellulose molecular chains assemble to form microfibrils. This assembly subsequently leads to the development of high-order bundles and clusters called fibril lamella and fibre cells (Shoda and Sugano, 2005). Plant cellulose forms a complex structure with impurities such as lignin and hemicellulose. Contrariwise, BC is secreted by $G$. xylinus cells fashioned into a ribbon-like structure composed of microfibril bundles. The fibre diameter of these ribbons are over a hundred times thinner than that of plant cellulose (Guhados et al., 2005). Due to the special ultrafine reticulated structure of BC, there are many unique characteristics that become apparent in their potential and current applications, these are discussed in the next section.

\section{Properties of Bacterial Cellulose}

$B C$ has a wealth of useful properties that allow it to be used in a wide range of applications, especially in industry and healthcare. The properties are dependent on the structural features as mentioned previously. When the BC pellicle is chemically purified and dried on a flat substrate, a thin and translucent cellulose membrane is established. This membrane holds a plethora of unique properties due to its fine and continuous network of crystalline microfibrils, both in its dried and wet (never-dried) state (Shibazaki et al., 1993).

$B C$ has been discovered to have the highest Young's modulus of any twodimensional organic material, at a staggering stiffness value of $15 \mathrm{GPa}$. The 
extraordinarily high stiffness arises from the strong interfibrillar binding in the network of its ultrafine fibrils and also owning to its high crystallinity (Yamanaka et al., 1989). The effect of sodium hypochlorite ( $\mathrm{NaClO}$ ) and sodium hydroxide $(\mathrm{NaOH})$ on the stiffness of the BC was investigated, the Young's modulus of the $\mathrm{BC}$ sheets further increased to $23 \mathrm{GPa}$ at a $0.5 \%$ concentration of $\mathrm{NaClO}$ and approached $30 \mathrm{GPa}$ at a concentration of $5 \% \mathrm{NaOH}$ (Nishi et al., 1990). Therefore, the mechanical properties of $\mathrm{BC}$ can be further improved with the treatment of alkaline or oxidative solutions, which can be beneficial in many industrial applications where greater stiffness is required. Post-processing of BC allows its mechanical properties to be tailored by exposing it to different chemical treatments, this is especially useful in applications where a highly specific stiffness is desired such as in tissue engineering and cellular wound healing (Chen et al., 2015; Wang et al., 2012).

$\mathrm{BC}$ shows further favourable mechanical properties with high tensile strength, afforded by its highly crystalline structure and fine diameter network of fibres which work together in unison with tensile loads. With a density of $1600 \mathrm{~kg} / \mathrm{m}^{3}, \mathrm{BC}$ microfibrils have an individual Young's modulus of $138 \mathrm{GPa}$ and a tensile strength of more than $2 \mathrm{GPa}$ (Dobre et al., 2010; Nishino et al., 1995). Aramid fibres, a class of heat-resistant and highly strong synthetic fibres used in body armour fabric and ballistic composites, show similar tensile strengths to that of BC, proving how much strength there is in its dense nanofibre network (Young et al., 1992). $\mathrm{BC}$ has shown good potential in material reinforcement in various composites which gives the newly formed composite greater mechanical properties (Gindl and Keckes, 2004; Yano et al., 2005).

Tissue engineering is a rapidly growing field which aims to restore, repair or maintain the function of various vital tissues and organs (Stock and Vacanti, 2001). Biomaterials have been widely used as tissue engineering scaffolds where an ideal material would successfully mimic the extracellular matrix and be able to guide the necessary cells towards effective tissue reformation. Being a natural polymer, BC proves to retain a high level of biocompatibility as shown by studies which show the in vitro and in vivo biocompatibility of BC. Especially, implantations of $\mathrm{BC}$ within rat models have successfully demonstrated biocompatibility with the absence of macroscopic indications of inflammation in response to the implant within the animal (Helenius et al., 2006). Absence of fibrotic encapsulations together with the absence of giant cells point towards good biocompatibility of the material in in vivo conditions. The results here are not surprising given that cellulose-based materials are generally considered biocompatible and thus invoke negligible inflammatory and foreign body responses (Miyamoto et al., 1989).

$\mathrm{BC}$ pellicles demonstrate a high level of chemical purity due to the absence of hemicellulose, lignin, pectin and other biogenic compounds (Song et al., 2009). Removal of hemicelluloses and lignin from cellulosic materials require difficult post processing which adds time and cost and would otherwise pose an economic burden in the manufacturing industry (Frederick et al., 2008). The energy requirement for the purification of $\mathrm{BC}$ is considerably lower than that of other cellulosic materials, allowing for a reduction in processing costs and chemicallyintensive processes which can form hazardous waste products (Gea et al., 2011). Compared to plant and other cellulose sources, BC offers a more economical (in 
terms of purification) and environmental source of cellulose which is unfortunately limited by its production rate.

Due to the nature of its ultrafine fibre network, BC has a very large surface area per unit mass, which gifts it the ability of having a very large water holding capacity. $\mathrm{BC}$ can hold up to 200 times its own dry mass in water, the majority of this liquid is not bound to the polymer and can be easily released via gentle pressing (Lin et al., 2009; Schrecker and Gostomski, 2005; Shezad et al., 2010). The excellent water holding capacity and water release rate of $\mathrm{BC}$ make it suitable as wound dressings. Capillary forces are responsible for holding the water in the cellulose pore structure where water is bound to the cellulose fibrils with hydrogen bonding (Gelin et al., 2007; Ul-Islam et al., 2012). Despite its high water holding ability, the actual BC fibres are very hydrophobic which permits it to be used in a wide range of civil and industrial applications (Feng et al., 2002; Marins et al., 2011; Yuyang et al., 2006).

$\mathrm{XRD}$ analysis on static-culture produced $\mathrm{BC}$ shows that this material has a crystallinity index of $50 \%$ (Krystynowicz et al., 2002). Cellulose produced by bacteria grown in agitated cultures have shown to acquire a reduced crystallinity compared to those produced in stationary cultures (Czaja et al., 2004). The movement and rotation in agitated cultures cause an external force of disturbance to the fibril crystallisation process, leading to lower crystallinity (Yan et al., 2008). Due to its high crystallinity however, BC has an incredibly low solubility and thus is limited in its processability ( $\mathrm{Hu}$ et al., 2014). It is insoluble in most common solvents that are used in the manufacturing industry which limits its potential applications in these fields. A few solvents have been found to dissolve BC such as lithium chloride with N,N-dimethylacetamide, sodium hydroxide/urea aqueous solutions and some ionic liquids (Lu and Shen, 2011; Phisalaphong et al., 2008; Shen et al., 2010). These solvents however pose problems in terms of processing costs, health and safety issues due to toxicity, environmental devastation and can also negatively alter the properties of the BC (Aral and Vecchio-Sadus, 2008; Qin et al., 2014). On the other hand, the low solubility of BC can be advantageous in applications where the stability of the material in response to various gas and liquids is crucial, such as in air or water filtration systems (Kosmider and Scott, 2002).

Cellulose, being the most abundant natural homopolymer, shows excellent biodegradability from both plants based and bacterial sources. BC is completely biodegradable in a wide range of environmental conditions, which makes it a promising candidate in environmental protection, biomaterial and tissue engineering applications ( Li et al., 2009; Wan et al., 2009). Another considerably attractive advantage of $\mathrm{BC}$ is its ability to be physically moulded into any form or size during synthesis (Bäckdahl et al., 2008). This mouldability does not come at the expense of causing any notable alteration to its physical properties. For example, BC grown in a petri dish will take up the shape and volume of the dish and will be formed into a circular gel-like pellicle. A summary of the properties of $\mathrm{BC}$ relating to wound healing can be found in Table 1.

Table 1: Table summarising the key properties of $B C$ and its relevance to wound healing. 


\begin{tabular}{|c|c|c|c|}
\hline Property & Advantage & $\begin{array}{l}\text { Benefits to Wound } \\
\text { Healing }\end{array}$ & References \\
\hline Biodegradability & $\begin{array}{l}\text { Bandage for } \\
\text { chronic wounds } \\
\text { potentially } \\
\text { doesn't need } \\
\text { removing }\end{array}$ & $\begin{array}{l}\text { Reduction of pain from } \\
\text { bandage removal }\end{array}$ & $\begin{array}{l}\text { (Hu and Catchmark, } \\
\text { 2011; Laçin, 2014) }\end{array}$ \\
\hline $\begin{array}{l}\text { ECM } \\
\text { Resembling } \\
\text { Matrix }\end{array}$ & $\begin{array}{l}\text { Biomimetic } \\
\text { structure } \\
\text { promotes prompt } \\
\text { wound healing }\end{array}$ & $\begin{array}{l}\text { Cells of the wound } \\
\text { response can be guided } \\
\text { to become more efficient }\end{array}$ & $\begin{array}{l}\text { (Svensson et al., } \\
\text { 2005; Wu et al., 2014) }\end{array}$ \\
\hline $\begin{array}{l}\text { Excellent } \\
\text { Biocompatibility }\end{array}$ & $\begin{array}{l}\text { Reduces } \\
\text { complications } \\
\text { with immune } \\
\text { rejection }\end{array}$ & $\begin{array}{l}\text { Risk of fibrotic scarring } \\
\text { is lower }\end{array}$ & $\begin{array}{l}\text { (Helenius et al., 2006; } \\
\text { Torres et al., 2012) }\end{array}$ \\
\hline High Stiffness & Great Durability & $\begin{array}{l}\text { Allows bandage to } \\
\text { withstand some trauma }\end{array}$ & $\begin{array}{l}\text { (Lin et al., 2013; } \\
\text { Nakayama et al., } \\
\text { 2004) }\end{array}$ \\
\hline $\begin{array}{l}\text { High Tensile } \\
\text { Strength }\end{array}$ & $\begin{array}{l}\text { Resistance } \\
\text { against tearing } \\
\text { as a wound } \\
\text { dressing }\end{array}$ & $\begin{array}{l}\text { Provides mechanical } \\
\text { protection against } \\
\text { external trauma }\end{array}$ & $\begin{array}{l}\text { (Naritomi et al., } \\
\text { 1998b; Wan et al., } \\
\text { 2009) }\end{array}$ \\
\hline $\begin{array}{l}\text { High Water } \\
\text { Uptake Ability }\end{array}$ & $\begin{array}{l}\text { Maintains moist } \\
\text { environment and } \\
\text { flow of wound } \\
\text { exudate }\end{array}$ & $\begin{array}{l}\text { Allows for a more } \\
\text { efficient recovery } \\
\text { process and } \\
\text { management of osmotic } \\
\text { environment of cells }\end{array}$ & $\begin{array}{l}\text { (Lin et al., 2009; } \\
\text { Schrecker and } \\
\text { Gostomski, 2005; Ul- } \\
\text { Islam et al., 2012) }\end{array}$ \\
\hline $\begin{array}{l}\text { Large Surface } \\
\text { Area }\end{array}$ & $\begin{array}{l}\text { Increased } \\
\text { interactions with } \\
\text { cells in the } \\
\text { wound response }\end{array}$ & $\begin{array}{l}\text { More efficient cellular } \\
\text { interactions leading to a } \\
\text { healthier recovery }\end{array}$ & $\begin{array}{l}\text { (Iguchi et al., 2000; } \\
\text { Nishi et al., 1990) }\end{array}$ \\
\hline
\end{tabular}

The unique structural and mechanical properties of BC make it suitable for use in

\section{Wound Healing} a variety of applications such as in food, electronics and medicine (Fontana et al., 1990; Jagannath et al., 2008; Shibazaki et al., 1993). However, out of all the applications, BC has revealed outstanding potential in wound healing and wound care products. The benefit of advanced wound care products and services that address infection and recovery times will function to revolutionise the healthcare industry, its impact would be remarkable for the entirety of the human population. As mentioned previously BC has valuable properties such as its high crystallinity, water holding and absorption capacity, low solubility in solvents and high tensile strength (Figure 3B). These features are all beneficial for skin repair materials.

A good wound repair material has the important characteristic to be able to absorb exudate during and after application and removal. Currently available wound care materials have traditionally showed good absorbance and permeability such as with gauzes which adhere to desiccated wound surfaces, but on removal can cause trauma and damage to the wound site (Boateng et al., 2008). When considering the properties of $\mathrm{BC}$ to current wound care materials, BC shows 
incredible promise in overcoming the downfalls associated with current dressings. Consequently, BC membranes have been used as either wound dressings or skin substitutes. The membrane produced by the bacteria can be directly used from the culture by simply washing the pellicle with water. BC can also be processed further if need be to suit the exact wound healing application.

In the late $20^{\text {th }}$ century, $\mathrm{BC}$ was first used as a temporary skin substitute and biological dressing under the trade name BioFill $\Theta$, now known as Dermafill ${ }^{\mathrm{TM}}$ (Fontana et al., 1990). The product was intended to treat patients suffering from various skin wounds as a result of burns, dermabrasion, cuts and ulcers. Since then, many other BC based products have been commercially available for topological application for wound recovery. Studies show that the use of BC membrane-based dressings establish superiority to conventional materials in reducing wound pain, retaining exudate, accelerating and facilitating reepithelialisation, reducing total healing times, diminishing infection rates and reducing visible scarring (Czaja et al., 2006; Czaja et al., 2007; Fontana et al., 1990). Moreover, due to the translucency of the BC dressing, it is remarkably simple and easy to inspect the wound, without interference or removal of the membrane from the patient.

During the wound healing process, correct moisture levels are required for efficient recovery times. Having a high-water holding ability, BC allows for the wound site to have the ideal moisture conditions. Furthermore, due to the network of its nanofibres, the membrane will prevent infection by creating a physical barrier that will prevent bacteria infiltrating into the wound site preventing the risk of infections (Kaewnopparat et al., 2008; Shezad et al., 2010). The heating of the skin in burn victims causes the breakdown of the semi-permeable membrane associated with the lipoprotein layer in the outermost layer of the skin (stratum corneum) (Jelenko et al., 1968). When the stratum corneum is destroyed, there is a substantial evaporative loss of water which is associated with a large degree of heat loss which can lead to hypermetabolism in burn patients (Lamke et al., 1977). The highwater absorptivity, water retention and vapour transmission features of BC creates an environment where the wound exudate is locked into the dressing whilst also preserving proper wound moisture during healing.

Owing to a multitude of hydroxyl groups, air-dried BC allows the for exceptional water vapour permeability which can be hugely beneficial in wound dressings (Fu et al., 2013). Using air-dried membranes allows for breathable dressings which permit the passage of water vapour through the material. Studies show that an ideal moisture content of a wound environment is one of the most important factors of successful wound healing (Fleck and Simman, 2010). Experimental values of controlled water vapour tests on wound re-epithelialisation and contraction enhancement show that in the case of a dressing with a water vapour transmission rate of $2028 \pm 237.8 \mathrm{~g} / \mathrm{m}^{2}$. $24 \mathrm{~h}$ was found to be in the optimal timescale for healing. (Xu et al., 2016).

A necessity for wound dressings is its competence in maintaining structural integrity between the time period of application and removal, especially when applied near joint areas where movement can cause failure of the dressings. The tensile strength of a BC membrane has been experimentally calculated to be approximately $15 \mathrm{MPa}$ with $32 \%$ elongation at break, the addition of chitosan can increase the Young's modulus (Lin et al., 2013). The tensile strength of BC 

membranes is also dependant of culture conditions and post treatment which can be found to as high as $260 \mathrm{MPa}$ (Kim et al., 2011; Yano et al., 2008). The elongation at break of $32 \%$ for the $\mathrm{BC}$ membrane reveals a high degree of toughness. These properties allow $\mathrm{BC}$ to be extremely suited in a wide range of wound dressings for different wound sites. For example, BC is both mechanically strong and flexible and can thus be produced and be given to patients with knee wounds where their movement will not be restricted and the dressing will not fail.

Cytotoxicity and cell attachment testing on BC membranes have shown that BC maintains high fibroblast viability which is highly desired in a dressing material as cell toxicity would be a major concern for any material that comes in contact with an open wound (Moreira et al., 2009). BC additionally accommodates high level of cell attachment due to its ultrafine network of nanofibers, this feature is especially useful in the progression of wound healing where enhanced cell attachment would play a role in healing acceleration (Diegelmann and Evans, 2004). Furthermore, the ultrafine network presents a high surface area to volume ratio that has potential in cell seeding which can facilitate faster wound regeneration.

The bio-absorbability of $\mathrm{BC}$ allows enhanced restoration of the targeted tissue in a wound environment. Bioabsorbable $\mathrm{BC}$ has been developed and tested in $\mathrm{pH}$ conditions that are commonly found in wound environments (Hu and Catchmark, 2011). It was shown that by incorporating BC with different cellulases, that the degradation rate of the material could be controlled. This permits modified BC to be able to degrade through a function of a predetermined and configurable time.

$\mathrm{BC}$ has shown similarity to the human carotid artery in its stress-strain response curve (Bäckdahl et al., 2006). The resemblance to soft tissue could be due to the comparable architecture of the carotid artery and $\mathrm{BC}$, but this finding also suggests that $\mathrm{BC}$ can be formed to be biomimetic towards tissue and skin. Numerous publications that $\mathrm{BC}$ is also similar to skin, making it suitable as a skin substitute material or a temporary wound treatment dressing (Ciechańska, 2004; Fu et al., 2013; Lee and Park, 2017). An ideal wound dressing system would present similarity to the autograft skin in structure and in functionality (Jones et al., 2002). By mimicking native soft tissue, wound care materials made of $\mathrm{BC}$ could prove to improve patient compliance.

Given its highly nano-porous structure, BC allows for the incorporation of pharmaceuticals and antibiotics into a wound, whilst simultaneously serving as an effective physical barrier against potential infections with its filter-like mesh of microfibrils. Porous fibres for the delivery of active pharmaceutical ingredients is not a new concept, drugs can be easily incorporated into the BC dressing to be released at a controlled or delayed release rate (van de Witte et al., 1993).

When $\mathrm{BC}$ grows in its native conditions, it takes the form of the surrounding environment such as the petri dish. The membrane remains highly mouldable even after extraction from the growth medium. Wounds come in different shapes and sizes and can occur at any part of the body and therefore should not be thought of as a flat surface. The mouldability of BC allows it to be placed on any wound irrespective of where it may be on the patient. BC-based wound dressings can be made to be extremely conformable to the exterior or wounds and allow great levels of comfort that is not experienced by standard gauzes. 
There has been an abundance of work focusing on the improvement of static culture methods for producing BC (Cakar et al., 2014; De Wulf et al., 1996; Vandamme et al., 1998). From an industrial point of view however, the fact remains that these culture systems are inefficient as they are labour intensive and have a long turnaround time. Johnson \& Johnson, a major pharmaceutical company, attempted the commercialisation of BC as early as in the 1980s. The company supported a pioneering series of investigations into the application of BC for different types of wounds, but details of any clinical trials have never been published, and many companies have failed to introduce a commercial wound healing product which incorporates the benefits of BC due to the many difficulties associated with the efficiency of large-scale fermentation (Ring et al., 1986a, b).

Commercial production of BC was again investigated in the 1990s by a number of large Japanese companies and governmental organisations aiming to efficiently mass produce BC (United and Congress, 1993). The $\$ 45$ million effort from these companies resulted in many patents and publications, however there was no indication of commercial success. The 1990's was also the decade when fundamental studies on BC biosynthesis was carried out in Poland. The government-backed initiative lead to successful clinical trials continuing through to the new millennium (Czaja et al., 2006). The study also led to the discovery of an efficient strain of Gluconacetobacter, which is able to produce cellulose in nutrient mediums which were more economical (Krystynowicz, 1997). Therefore, there was a shift in focus to unearthing strains of Gluconacetobacter which would result in higher yields and production rates of BC. The discovery of more efficient bacterial strains allows for advancement into fermentation scale up with promise of commercialisation.

The major obstacle preventing commercialisation is the efficiency of the current production technologies. Manufacturers of BC based artificial skin have been varying concentration of carbon sources, surface/volume ratios of the cultures, and duration of fermentation in the effort to scale production (Czaja et al., 2006). Unlike other bacterial polysaccharides, BC cannot feasibly be synthesised economically in large stirred-tank fermentation systems. Agitated microbial cultures have been shown to have a reduction in cellulose yield and a loss of attractive properties such as crystallinity.

Until very recently, a different approach to $\mathrm{BC}$ manufacturing has been on the rise with numerous publications from both academia and industry. The endeavour to form BC into a secondary fibrous form via highly controlled fibre forming techniques has seen a rise. Fibre forming techniques such as electrospinning have been utilised to create ultrafine fibres with $B C$ that can be used in a wide range of potential applications such as drug delivery, tissue engineering and wound healing (Abeer Muhammad et al., 2014; Mohd Amin et al., 2012; Svensson et al., 2005). The benefit of being able to process BC into fibres are vast. The ability to produce continuous nano- and micro-fibres from BC allows for the fabrication of bandages from small amounts of raw material. Furthermore, this allows for the tailor ability of fibre morphology and also allows for potential industrial scale up of $\mathrm{BC}$ manufacturing which requires less raw or pure BC. 
Electrospinning is an electrohydrodynamic technology in which a polymer solution is fed through a needle that is connected to a high voltage power supply (Luo et al., 2012). The solution becomes charged as it flows through the needle and the electrical stresses overcome the surface tension of the polymer solution (Deitzel et al., 2001). The droplets emerging from the tip of the needle converge into a conical shape (Taylor cone) as a result of the balance between various forces, and a polymer jet is ejected from the apex of this cone (Kim and Reneker, 1999). It is this jet that leads to the production mechanism as the solvent subsequently evaporates and in its stead leaves dried, uniform fibres (Feng, 2002). The technology is summarised by (Figure 4).

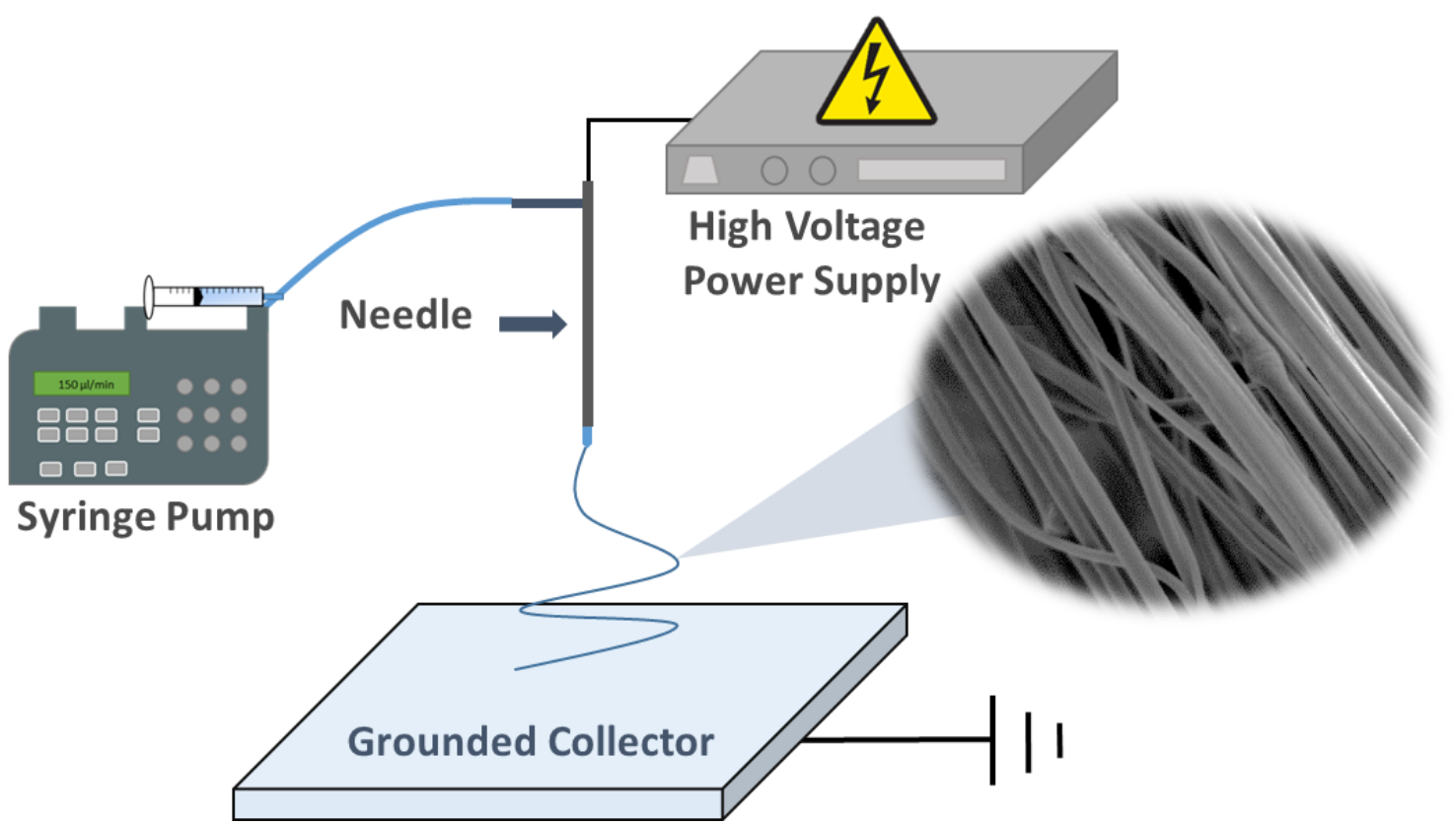

Figure 4: Schematic representation of the electrospinning setup showing a syringe pump where polymer solution is fed through the needle, upon contact with a high voltage electric field, a Taylor cone appears, and fine fibres are formed produced as a result.

Being one of the more established laboratory fibre forming techniques, much attention has gone into forming fibres via this facile technique. BC nano whiskers have been used to improve the mechanical properties of other fibres which are produced by other polymers. The improvement of mechanical properties mainly depends on the extent of BC nano whiskers dispersion in the fibres within the matrix. These whiskers are high aspect ratio (length to diameter ratio) cellulose crystal suspensions, extracted from the cellulose source and reveal a needle like structure under SEM (Bercea and Navard, 2000). They are identified as whiskers due to their elongated shape and their high crystallinity achievement, by creating mixtures of these crystal suspensions with polymer lattices, there is a drastic enhancement of mechanical properties at even a low weight fractions (Favier et al., 1997). BC whiskers can also be obtained by acid hydrolysis of the BC microfibrils, forming highly crystalline rod-like particles (Dufresne, 2000). 
Blends of $\mathrm{BC}$ and Poly(ethylene oxide) (PEO), a water soluble polymer have The solution was able to form fibres such as the PEO would, the BC whiskersreinforced fibres showed a significant increase in Young's modulus, percentage extension at break and maximum stress. Furthermore, ethylene vinyl alcohol (EVOH) fibres were also spun with electrospinning, XRD studies showed that the $\mathrm{BC}$ whiskers had a highly crystalline structure $(73.1 \%$ crystallinity index $)$ compared to untreated BC membranes (Martínez-Sanz et al., 2011). There is an abundance of polymers used in biomedical and tissue engineering that suffer from poor mechanical properties, therefore, electrospinning of $\mathrm{BC}$ has shown to have great potential in composite material reinforcement (Gindl and Keckes, 2004; Pommet et al., 2008; Wan et al., 2009).

More recently, improvements in the portability of electrospinning devices have allowed for point-of-need spinning of fibrous constructs with great potential in wound healing applications (Sofokleous et al., 2013). The ability to directly spray an active patch onto a wounded patient allows for the control of fibre morphology, patch thickness, material choice, easy transport and storage of nanofibrous products and gives complete control over wound coverage and thickness. Polycaprolactone ( $\mathrm{PCL}$ ) was used as a carrier polymer along with 8 differing ratios of $\mathrm{BC}$ to generate BC-PCL composite nanofibres which could be exploited in use as emergency point-of-need wound care using a novel electrohydrodynamic gun (Aydogdu, M. O. et al., 2018). BC was processed into fibres after being suspended in dimethylformamide (DMF) and subjected to ultrasonication to form a gel-like solution that could be mixed with the PCL polymer solution. BC shows only slight solubility in DMF, but the sonication process reduces the particle size of the $\mathrm{BC}$ membrane to improve solubility.

From the electrohydrodynamic gun study on $\mathrm{BC}$, it was found that the increase in $\mathrm{BC}$ content from 5 to $10 \mathrm{wt} \%$ resulted in an increased frequency of beads in the fibres (Aydogdu, Mehmet Onur et al., 2018). However, it was also observed that the bead count could be reduced by increasing the carrier polymer concentration. Other experimental studies show that the main factors which contribute to bead formation in electrospinning are to do with solution properties such as: low molecular weight, low concentration, low viscosity, high surface tension and low charge density (Fong et al., 1999). The solution properties of the BC-PCL solutions where experimentally measured, it was found that the increase of $\mathrm{BC}$ content from 5 to $10 \mathrm{wt} \%$ actually increased viscosity and electrical conductivity but only slightly increased the surface tension of the solution. The increased presence of beads in this case may be due to the rise in surface tension seen from the addition of $\mathrm{BC}$, other than the other measured solution properties.

An important property of $\mathrm{BC}$ is it's biocompatibility and ability to mediate cellular interactions similarly to that of native tissue in numerous instances (Bäckdahl et al., 2006; Torres et al., 2012). The produced BC-PCL fibres where tested with Saos-2-human osteosarcoma cell line which had osteoblastic characteristics (Rodan et al., 1987). In an MTT assay after 72 hours, all BC-PCL fibrous samples showed cell viability in excess of $75 \%$. It was found that by increasing the PCL concentration, the cell viability increased, possibly due to the increase in fibre diameter favoured by the cells. In the case for 5 and $15 \% \mathrm{PCL}$, cell viability increased with increasing BC content, however due to the cell viability of PCL 
alone being very high, it is difficult to determine whether any increase in cell viability was due to an increase in $\mathrm{BC}$ content. Nonetheless, it can be concluded that a BC-PCL composite system is very capable of retaining an acceptable level of cell viability.

The cellular interaction with the BC-PCL scaffolds were observed by SEM. Cells appeared to cover the scaffold and fill the spaces in the nanofibre matrix. Here were two dominant cell morphologies that could be determined from the micrographs, the cells along the axial length of the fibres depicted an elongated morphology whilst globule-shaped cells where seen at the intersections of the fibres. The presence of the elongated cells indicated that cytoskeletal rearrangement may have taken place which has been previously reported to activate nearby receptors which affects gene expression (Curtis and Wilkinson, 1997). The ability for a material to absorb water is an important factor in a wound dressing, a high swelling ratio permits exudate absorption and the efficient exchange of nutrients and waste (Martin, 1997). All BC-PCL samples showed a high level of water uptake in swelling tests whilst the sample with the highest concentration of $\mathrm{BC}$ and polymer showing the highest swelling percentage.

Nerve tissue engineering is a popular topic in biomedicine due to the limited regeneration capacity of native nerves. A study into the production of nanofibrous scaffolds for enhancing peripheral nervous system neural tissue regeneration and neurite outgrowth was carried out using a BC-PCL polymer mix (Altun et al., 2019). When a gap larger than $3 \mathrm{~cm}$ between peripheral nerves occurs, axon regrowth is extremely difficult, nerve tissue engineering thus provide scaffolds that aid this crucial regeneration (Monaco et al., 2017). Here a concentration of $5 \%(w / w) ~ B C$ was dissolved in a 50:50 solvent ratio of chloroform and DMF, dissolution required ultrasonic agitation of 5 hours over a period of 15 days. The dissolution process was captured optically every 3 days: days 1-3 showed no disintegration of the BC, days 4-6 showed slight disintegration, days 7-9 illustrated decomposition of the BC particles, at days 10-12 the dissolution process continued where whisker-like structures where observed, day 15 showed good dissolution (Figure 5). Mechanical strength is important in nerve tissue engineering as the constructs must be able to withstand the forces and motion of everyday interaction and movement where nerves will stretch and contract. The addition of $\mathrm{BC}$ into the fibrous scaffold doubles the tensile strength from 14.6 MPa to 29.3 MPa. The average diameter of the produces fibres for the PCL scaffolds was $527 \mathrm{~nm}$ and for the BC-PCL scaffolds there was a range of $70-120 \mathrm{~nm}$. 

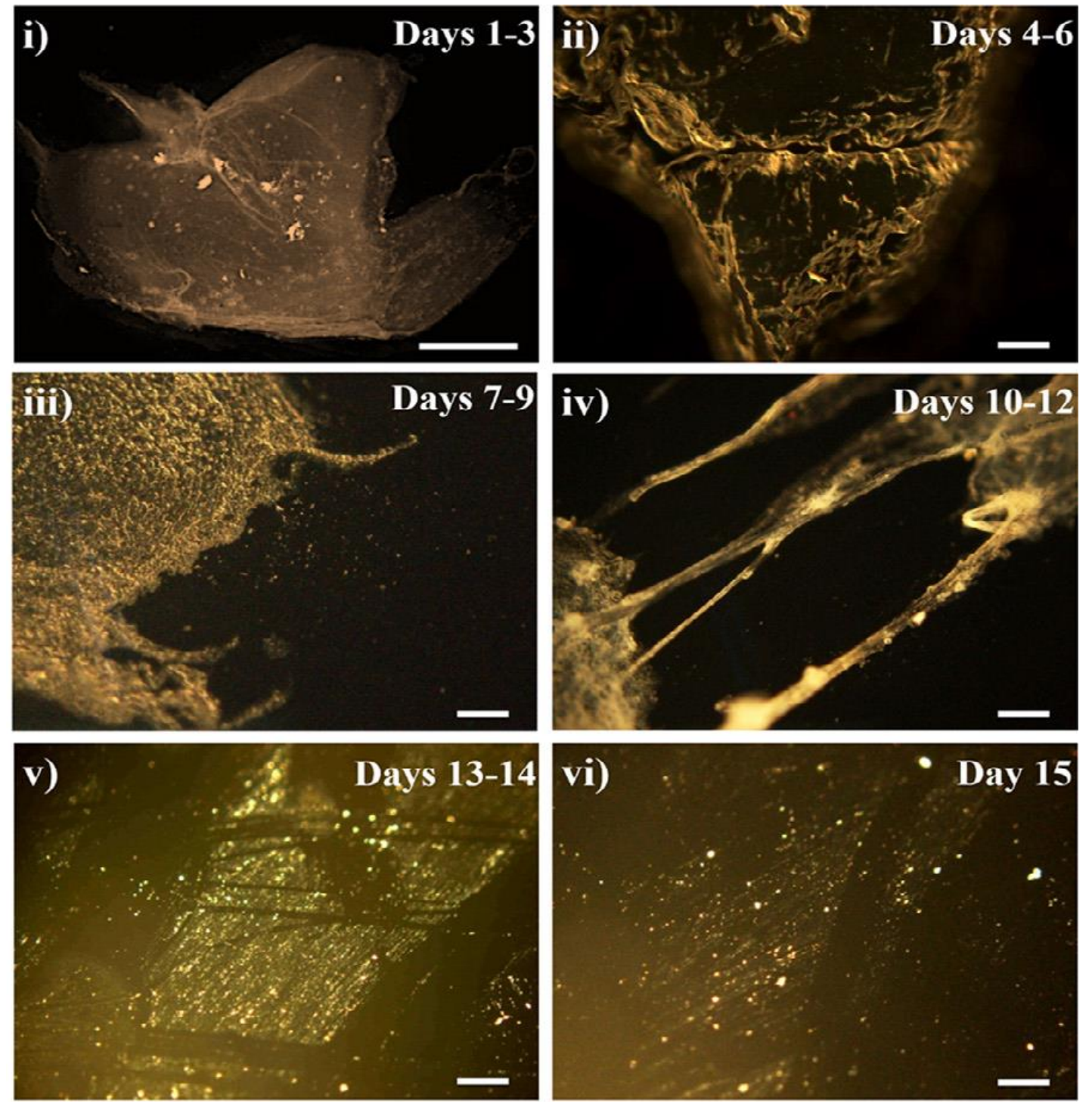

Figure 5: BC dissolution process is illustrated using optical microscope images:

634 (i) Days 1-3, (ii) Days 4-6, (iii) Days 7-9, (iv) Days 10-12, (v) Days 13-14 and 635 (vi) Day 15. Scale bar $=1 \mathrm{~mm}$ (Altun et al., 2019).

The hybridisation of fibre scaffolds with hydrogels improves mechanical durability and alters its biocompatibility and functionality (Kouhi et al., 2019). A concurrent electrospinning/electrospraying technique was utilised to produce fibrous hydrogel of keratin/ tragacanth gum-conjugated BC hydrogel (Azarniya et al., 2019). The setup was centred around a rotating mechanical mandrel where two separate electrohydrodynamic setups could deposit onto it, on one side was an electrospinning needle and on the other was an electrospraying needle. The into the fibre network without having an effect on its porosity or diameter 645 distribution. The hybrid product would act as a temporary skin substitute, in order 646 to cope with the mechanical durability demands, BC was incorporated into the 647 fibrous mats at different concentrations. In this work a concentration of 1,3 and 5 648 wt\% BC was prepared in a solution with keratin and PEO where acetic acid was 649 used as the solvent. The produced fibrous mats without BC had an average fibre 650 diameter of $243 \pm 57 \mathrm{~nm}$. With the addition of BC, it was noticed that there were 651 fibre breakdowns and a higher number of inter-fibre bonds present which may be 
652 the result of $\mathrm{BC}$ affecting the solvent evaporation rate. The formation of fibre 653 branches when BC was added can be explained by the theory that the surface of 654 a conductive fluid jet can undergo statistic equilibrium undulations via the combined effects of surface tension and electric Maxwell stresses (Yarin et al., 2005). Remarkably, the average fibre diameter was reduced to $150 \pm 43 \mathrm{~nm}$ when $\mathrm{BC}$ was added at $1 \%$ and subsequent higher conditions did not yield much change in the fibre diameter.

Hydrophobicity is an important characteristic to consider for materials in wound healing and in tissue engineering as it can affect biocompatibility of protein adsorption and cellular interaction with the material (Pertile et al., 2010). The keratin-based nanofibers produced without $\mathrm{BC}$ were hydrophobic and had a water contact angle of $126^{\circ}$. The addition of BC saw the hydrophobicity to significantly reduce and at $1 \mathrm{wt} \% \mathrm{BC}$, the water contact angle was $83^{\circ}$. This enhanced hydrophobicity of the fibres and is due to the hydrophobic nature of $\mathrm{BC}$ via its highly porous nonwoven network of nanofibrils. The incorporation of BC into the fibres also shows a significant enhancement in mechanical strength. At only $1 \%$ $\mathrm{BC}$ concentration and compared to keratin-PEO fibres, there is an increase from 7.1 $\mathrm{MPa}$ to $13.3 \mathrm{MPa}$ in the tensile strength,123 MPa to $250 \mathrm{MPa}$ in the elastic modulus and reduction in the elongation at break from about $15 \%$ to $10 \%$. The enhanced mechanical durability of the BC-reinforced fibres is probably afforded by the reorientation of the $\mathrm{BC}$ fibrils and the entanglements between the keratinPEO fibres (Astley et al., 2003). Furthermore, the interfacial cohesion between the $\mathrm{BC}$ and the keratin-PEO fibres in addition to the reduction in fibre diameter from the inclusion of BC can also be responsible for the improved mechanical properties (Wan et al., 2009). The study also carried out in vitro cell studies with the fibres, it was found that keratin-BC fibrous composites had an acceptable level of cytocompatibility as assessed through MTT assays where there was over $90 \%$ cell viability in L929 fibroblast cells (Azarniya et al., 2019).

\subsection{Pressurised Gyration}

Pressurised gyration is a hybrid fibre forming technique which combines solution blow spinning with centrifugal spinning to form low diameter fibres with a rapid production rate and can be used to generate bandage-like fibrous mats (Ahmed et al., 2019; Heseltine et al., 2018; Mahalingam and Edirisinghe, 2013). The setup consists of an aluminium vessel with multiple small apertures on its exterior which is connected to a high-speed motor and a gas inlet. The vessel rotates at high speeds and gas is infused simultaneously into the vessel which drives the polymer solution out through the orifices forming a polymer jet (Ahmed et al., 2018). The polymer jet gives rise to fibre production much like electrospinning as the solvent evaporates. This technique not only allows for very high throughput of production, but also allows you to control final fibre morphology by varying the rotation speed and the magnitude of applied gas pressure (Alenezi et al., 2019). Orientation of fibre bundles to generate mats of wound dressings can be manufactured in this way.

BC fibres blended with poly(methyl methacrylate) (PMMA) at several different ratios have been successfully formed with pressurised gyration to produce biocompatible fibrous scaffolds (Figure 6) (Altun et al., 2018a). 5 and $10 \mathrm{wt} \%$ of $\mathrm{BC}$ solutions were made in a 50:50 wt:wt ratio in DMF and tetrahydrofuran (THF). 
The BC was subjected to ultrasonication for an hour in order to form a gel that could be spun using pressurised gyration. The ratio of BC:PMMA was altered and physical properties were determined along with further tests including SEM imaging, fourier-transform infrared spectroscopy (FT-IR) and cell proliferation studies. Solution viscosity and surface tension was discovered to have increased with elevating BC-PMMA wt ratios, similar with electrospinning, these parameters fundamentally alter fibre formation in pressurised gyration. SEM imaging showed greater particle count on the fibres with higher ratios of BC-PMMA, indicating that these particles were caused by the higher BC content. The FT-IR spectra on the $\mathrm{BC}$-PMMA fibres confirmed presence of $\mathrm{BC}$ on the fibres as the profiles were consistent with that of pure $\mathrm{BC}$ and PMMA.

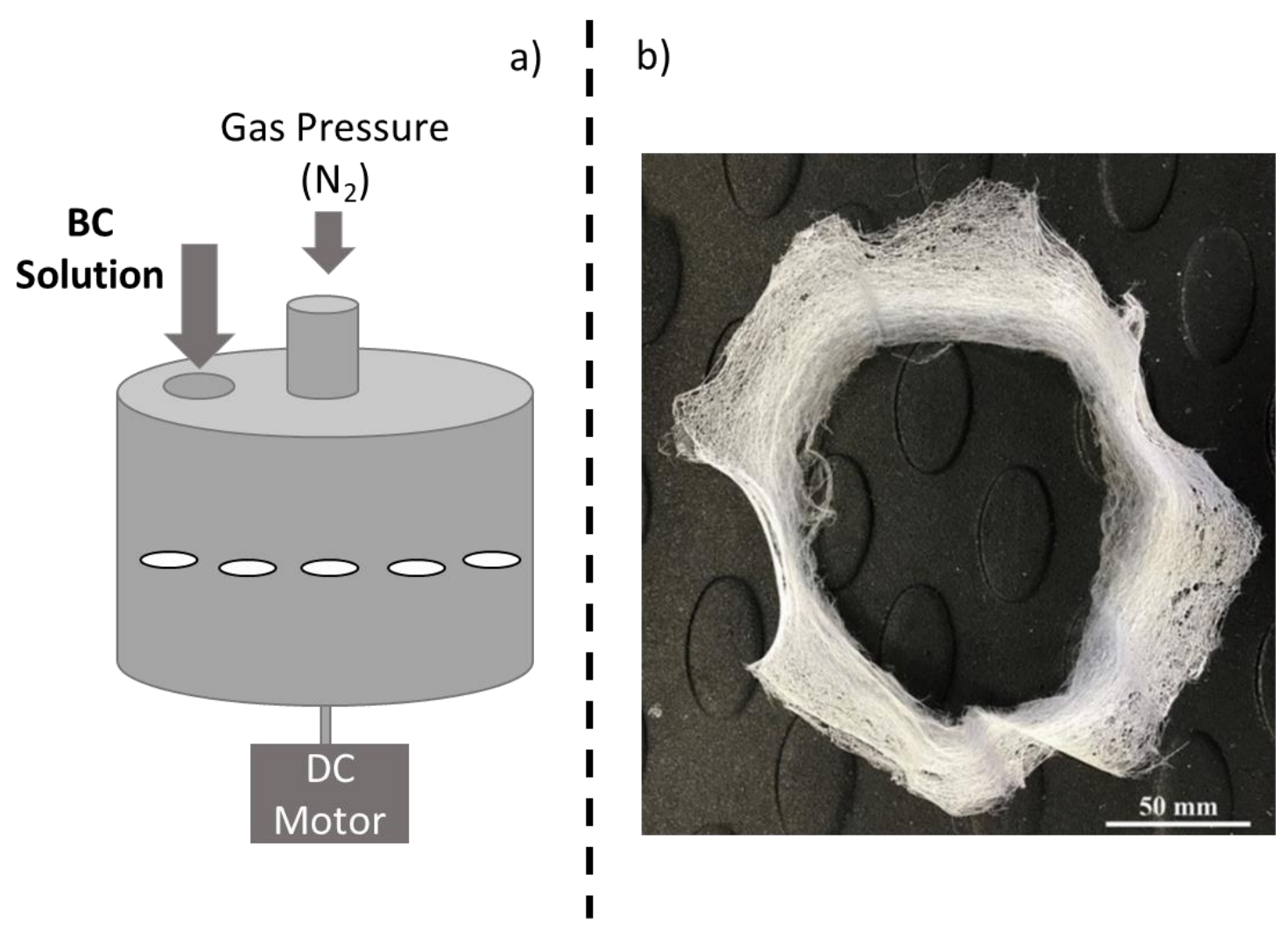

Figure 6: Schematic representation of a) pressurised gyration setup, b) Photograph of the bandage-like fibrous mat produced from the 5:50 (wt ratio) $\mathrm{BC}:$ PMMA blend.

Having applications in wound healing the scaffold must be biocompatible, nontoxic and must allow for adequate cell attachment, migration, proliferation and differentiation (Sachlos and Czernuszka, 2003). BC-PMMA scaffolds produced by pressurised gyration where investigated and found to be biocompatible with no indication of toxicity to the tested Saos-2 cell line. Adding BC to the BC-PMMA fibres increased cell viability compared to just solely using PMMA fibres. BCPMMA scaffolds with $5 \mathrm{wt} \% \mathrm{BC}$ were considered appropriate for wounds dressing applications because they retained cell viability of over $85 \%$. The produced scaffold demonstrated cell spreading and proliferation of DAPI stained cells, the scaffolds showed enhanced metabolic activity compared to the control (Figure 7). MTT assays demonstrated that the scaffolds of $5 \mathrm{wt} \%$ had improved metabolic 
activity and proliferation of the seeded cells compared to the $10 \mathrm{wt} \% \mathrm{BC}$.

728 Furthermore, preliminary mechanical tests on the scaffolds revealed that the BC729 PMMA fibres had lower stiffness and higher ductility, the tensile strength of 5:50 730 BC-PMMA was 2.6 times greater than PMMA fibres produced by electrospinning.
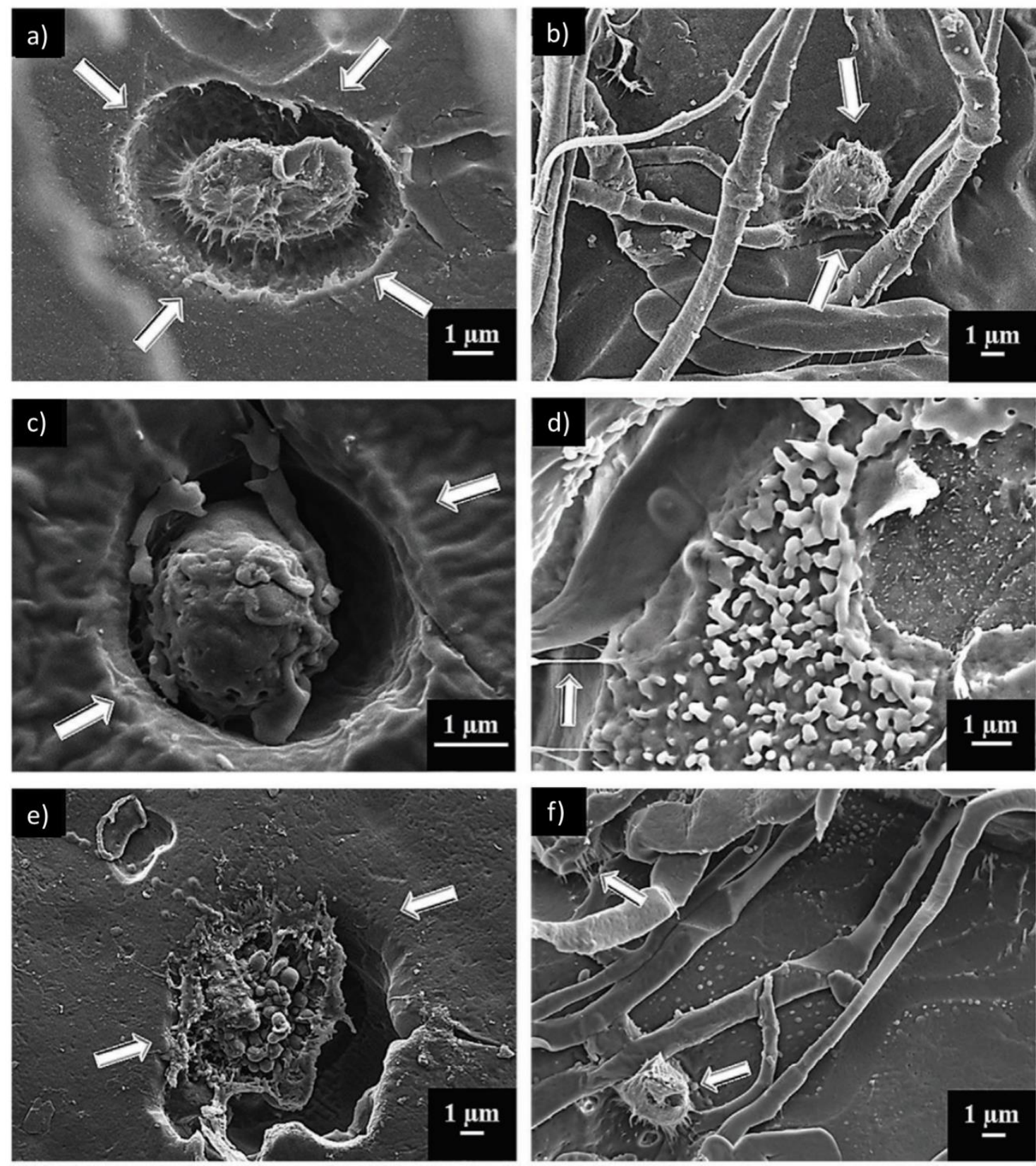

Figure 7: Scanning electron microscopy images of the BC:PMMA scaffold samples 72 hours after incubation with Saos-2 cell line with ratios of: a) 5:30, b) 10:20, c) 5:40, d) 10:30, e) 5:50, and f) 10:40. Arrows indicate embedded cells and their extension (Altun et al., 2018a).

Bandage-like polymeric structures were also produced using pressurised gyration using $\mathrm{BC}$ and PMMA blends with the addition of metallic antimicrobial nanoparticles (Altun et al., 2018b). In this study, BC was incorporated into a polymer solution of PMMA using sonication in a 50:50 solvent mixture of DMF and THF. Additionally, two types of nanoparticle mixtures were also added; one using $\mathrm{Cu}-\mathrm{Ag}-\mathrm{Zn} / \mathrm{CuO}$ and the other including $\mathrm{Cu}-\mathrm{Ag}$-Tungsten carbide. The study 

showed that BC-PMMA bandage-like fibres could be produced at a high yield with pressurised gyration and that these fibres can have antimicrobial nanoparticles incorporated for improved mechanical properties, higher water uptake ability and lower cell cytotoxicity.

An investigation into the maximal loading of $B C$ in binary and ternary blends of fibres was carried out with an emphasis on production yield and mechanical properties by (Aydogdu et al., 2019). Poly(lactic acid) (PLA) and PCL fibres were created with and without blends of BC, eventually an optimised composite of PCLPLA-BC was also created. For pure PLA fibres, there was a 92\% yield, and the addition of $B C$ into the polymer matrix caused a deterioration of yield down to $54 \%$ at only $10 \mathrm{wt} \% \mathrm{BC}$. It was observed that a huge fall in yield occurs as a result of higher BC loadings, as attested to by many other articles (Altun et al., 2018b; Aydogdu et al., 2019; Azarniya et al., 2019). Pure PCL fibres had a yield of $87 \%$ and saw a drop to $61 \%$ yield when loaded by $10 \mathrm{wt} \%$ BC. PLA and PCL composites were also produced and tested to compare the ternary behaviour of the different polymer systems. The 90:10 PLA-PCL blend had a very high yield of $97 \%$, which also showed that these polymers worked very well as composites.

A BC concentration of $30 \mathrm{wt} \%$ was deemed the highest concentration whilst maintaining an acceptable level of yield (>30\%) and mechanical integrity. The BC in the polymeric solution also caused an increased frequency of beads within the fibres. As expected, the addition of BC to the solutions lead to an increase in viscosity and thus caused thicker fibres to be formed in the presence of $\mathrm{BC}$.

With an increasing concentration of BC in PLA binary systems, the ultimate tensile increases with each $10 \%$ increment. PLA alone has a tensile strength of $2.3 \mathrm{MPa}$, at $10 \mathrm{wt} \% \mathrm{BC}$ concentration the tensile strength is $3.8 \mathrm{MPa}, 20 \mathrm{wt} \%$ it's at $5.4 \mathrm{MPa}$ and at $30 \mathrm{wt} \%$ it is $6.5 \mathrm{MPa}$. At $40 \mathrm{wt} \% \mathrm{BC}$ concentration, the PLA fibres lose mechanical integrity and the tensile strength drops to $2.3 \mathrm{MPa}$ as the $\mathrm{BC}$ content increases. This drop in tensile strength corresponds with the reduced fibre count and yield with high $B C$ levels which impairs the integrity of the bandages. The results for the stiffness of the PLA-BC binary system follows the same trend. The stiffness of PLA increases from $10 \mathrm{wt} \%$ to $30 \mathrm{wt} \%$ of added BC, it then falls sharply at $40 \mathrm{wt} \%$ and continues to drop.

The mechanical behaviour of the PLA-BC binary polymer system follows a similar trend with the PLA-BC polymeric fibres. With $100 \% \mathrm{PCL}$, the tensile strength is around $2.3 \mathrm{MPa}$, the addition of $10 \mathrm{wt} \% \mathrm{BC}$ creates an increase in tensile strength to about 2.7 MPa. PCL proves to be a superior carrier of BC compared to PLA when comparing tensile strength as $50 \mathrm{wt} \% \mathrm{BC}$ shows the highest value at around 6.7 MPa. At a $100 \%$ concentration of PCL, the Young's modulus is around 23 $\mathrm{MPa}$, the addition of $\mathrm{BC}$ at $10 \mathrm{wt} \%$ causes an increase of stiffness to about 27 $\mathrm{MPa}$ and at a 40 wt \% concentration of $\mathrm{BC}$ the stiffness drops to $\sim 12 \mathrm{MPa}$.

This study then focused on the production of PCL and PLA fibres with BC loading, ultimately to design an optimised ternary polymeric system with a mixture of PCL, PLA and BC. The optimised ternary sample consisted of $70 \mathrm{wt} \%$ mixture of PLA and PCL and $30 \mathrm{wt} \% \mathrm{BC}$, it had a higher tensile strength than both PCL and PLA at around $9 \mathrm{MPa}$ and had a high stiffness of around $19.6 \mathrm{MPa}$. It showed that BC can be used in binary and ternary polymeric systems to produce fibres that can benefit from the mechanical characteristics of multiple polymers. 
792 Due to the large number of inter- and intra- molecular hydrogen bonds, BC is very difficult to process into solution, which is a necessity in order to generate fibres using major methods such as electrospinning. BC is an especially insoluble material and does not dissolve in common organic solvents such as acetone, chloroform and DCM. Experimental results show that BC has partial solubility in $8.5 \mathrm{wt} \%$ aqueous sodium hydroxide $(\mathrm{NaOH})$ solution (Łaskiewicz, 1998). Even then, temperatures of $-5^{\circ} \mathrm{C}$ are required, only about $20 \mathrm{wt} \%$ of the cellulose is dissolved and the degree of polymerisation of the $\mathrm{BC}$ source must be low too. The solubility of $\mathrm{BC}$ in $\mathrm{NaOH}$ solution can however be further increased when $1 \mathrm{wt} \%$ urea is added. Even then, BC is not completely soluble in these conditions, and the use of such acids and chemicals can lead to toxic production environments and hazardous industrial waste.

High molecular weight BC was discovered to be soluble in a binary solvent system of lithium chloride/N,N-dimethylacetamide (LiCl/DMAc) (Shen et al., 2010). It was also found that the type of BC membrane and how it was formed had a large effect on its solubility with these solvents. BC samples with large grains in their microstructure were more prone to form large gels during the swelling stage of dissolution which hindered additional diffusion of the solvent into the fibres. The samples that showed good solubility were those that were in powdered form, having much higher surface area to volume ratio. There are several activation procedures that can improve the initial solubility of cellulose and BC including treatment with liquid ammonia, freeze drying and swelling in water followed by solvent exchange in dimethylacetamide (Morgenstern and Berger, 1993; Rohrling et al., 2002). These activation steps are thought to induce inter- and intracrystallite swelling, increase accessibility and break of hydrogen bonds. Temperature was also found to have a marked effect on dissolution where temperatures below $45^{\circ} \mathrm{C}$ caused difficulty in dissolution and activation temperatures over $60^{\circ} \mathrm{C}$ showed greater dissolution.

BC with a high degree of polymerisation (6500) was dissolved in 1-n-butyl-3methylimidazolium where temperatures of $80^{\circ} \mathrm{C}$ and 12 hours of mechanical stirring were required (Schlufter et al., 2006). The dissolution by 1-n-butyl-3methylimidazolium was found not to significantly degrade the polymer chains. The ionic liquid, 1-allyl-3-methyl-imidazolium chloride was also used to dissolve BC but a transition from cellulose I to the cellulose II allomorph was observed with the resulting electrospun fibres (Chen et al., 2010).

Although solubility of $\mathrm{BC}$ has been observed with some ionic liquids, the case remains that these solutions would pose an obstacle in the mass production of $B C$ fibres and other derivative wound care materials. Firstly, the acute toxicity of these liquids is a great concern at both the factory level and through run-off. For example, the toxicity caused by 1-butyl-3-methylimidazolium chloride was investigated in zebrafish and it was found to cause oxidative damage as well as DNA damage (Zhang et al., 2017). Furthermore, the economics of such solvent systems, binary and otherwise, increase the costs to the end consumer with higher processing expenditures and prolonged manufacturing times. High temperature 
processing of $\mathrm{BC}$ increases energy input during manufacturing which is both environmentally and economically detrimental.

\section{Future Developments and Conclusions}

The secondary processing of $\mathrm{BC}$ has proven to be difficult. Due to its nature, large scale production of $\mathrm{BC}$ in wound care materials is not feasible. Therefore, by reprocessing the $\mathrm{BC}$ into secondary fibres and blends, there can be a more commercially feasible methods of mass-producing for the healthcare market. The answer may lie in fibre forming techniques such as electrospinning and pressurised gyration, these methods allow for the tailoring of the fibre structure to best suit for wound healing applications.

However, the solubility of $\mathrm{BC}$ has played a major obstacle in forming spinnable solutions. Work needs to be done to discover solvents that can dissolve the BC membrane in a non-toxic and economical manner, as well as to not remove the fundamental properties of high utilisation value. Spinnable solutions can then be processed into fibres, added to blends containing other natural polymers which can have antibacterial and pro-wound healing effects.

An alternative approach into forming $\mathrm{BC}$ solutions can be to use mechanical force, whereby the BC membrane is broken into smaller particles or fibrils which may improve its solubility in several solvents. Such an approach has been used to spin BC-PMMA scaffolds as discussed previously where high frequency ultrasound has been used to form a gel-like spinnable solution within a carrier polymer. As discussed earlier, the benefit of using ultrasonication is that the crystal structure of the BC is not adversely affected and thus the beneficial wound-healing properties of the material can remain. Moreover, other mechanical methods of reducing $B C$ size can be investigated, such as grinding or blending the $B C$ into particles. The efficacy of such particles in wound healing needs to be also determined.

Blends of $\mathrm{BC}$ within different polymers, both synthetic and natural could prove to be a beneficial commodity in wound care. Composite materials with desired properties such as biocompatibility, biodegradability and anti-bacterial properties can be used to develop wound dressings that overcome the limitations of the production limitation of $\mathrm{BC}$. There are many polymers systems yet to be trialled, even with the difficulty of processing $\mathrm{BC}$, it can still be used to enhance the mechanical and biological properties for effective wound healing.

The remarkable properties of BC were only discovered in the mid-1980s, where before the applications of the it was only really limited to food production of natade-coco. Since then, there has been a steep incline in the number of research articles and patents relating to $\mathrm{BC}$ and various methods for extraction and processing.

A considerable challenge to overcome in $\mathrm{BC}$ technology is the unearthing of a suitable carbon source that is cheap and that does not compete with the production of food. Nevertheless, forming BC membranes into secondary fibres could maximise the use of the material in wound care applications and reduce the volume required to have its clinical effects. There are still many hurdles remaining for the wide use of $\mathrm{BC}$ in healthcare settings, but with the abundance of research 
and patents, we could be on the verge of incorporating this very significant and valuable material in crucial advanced technology applications worldwide.

\section{Acknowledgements}

The authors would like to thank University College London for supporting the doctoral research of Jubair Ahmed and for hosting a period of visiting research by Merve Gultekinoglu at the Edirisinghe Lab in UCL.

\section{Conflict of Interest}

The authors declare no conflict of interest.

\section{References}

Abeer Muhammad, M., Mohd Amin Mohd Cairul, I., Martin, C., 2014. A review of bacterial cellulose-based drug delivery systems: their biochemistry, current approaches and future prospects. Journal of Pharmacy and Pharmacology 66(8), 1047-1061.

Ahmed, J., Altun, E., Aydogdu, M.O., Gunduz, O., Kerai, L., Ren, G., Edirisinghe, M., 2019. Antifungal bandages containing cinnamon extract. International Wound Journal 16(3), 730-736.

Ahmed, J., Matharu, R.K., Shams, T., Illangakoon, U.E., Edirisinghe, M., 2018. A Comparison of Electric-Field-Driven and Pressure-Driven Fiber Generation Methods for Drug Delivery. Macromolecular Materials and Engineering, 1700577.

Alenezi, H., Cam, M.E., Edirisinghe, M., 2019. Experimental and theoretical investigation of the fluid behavior during polymeric fiber formation with and without pressure. Applied Physics Reviews 6(4), 041401.

Altun, E., Aydogdu Mehmet, O., Koc, F., Crabbe-Mann, M., Brako, F., Kaur-Matharu, R., Ozen, G., Kuruca Serap, E., Edirisinghe, U., Gunduz, O., Edirisinghe, M., 2018. Novel Making of Bacterial Cellulose Blended Polymeric Fiber Bandages. Macromolecular Materials and Engineering 303(3), 1700607.

Altun, E., Aydogdu, M.O., Crabbe-Mann, M., Ahmed, J., Brako, F., Karademir, B., Aksu, B., Sennaroglu, M., Eroglu, M.S., Ren, G., Gunduz, O., Edirisinghe, M., 2018. Co-Culture of Keratinocyte-Staphylococcus aureus on $\mathrm{Cu}-\mathrm{Ag}-\mathrm{Zn} / \mathrm{CuO}$ and $\mathrm{Cu}-\mathrm{Ag}-\mathrm{W}$ Nanoparticle Loaded Bacterial Cellulose:PMMA Bandages. Macromolecular Materials and Engineering, 1800537.

Altun, E., Aydogdu, M.O., Togay, S.O., Sengil, A.Z., Ekren, N., Haskoylu, M.E., Oner, E.T., Altuncu, N.A., Ozturk, G., Crabbe-Mann, M., Ahmed, J., Gunduz, O., Edirisinghe, M., 2019. Bioinspired Scaffold Induced Regeneration of Neural Tissue. European Polymer Journal 114(2019), 98-108. Aral, H., Vecchio-Sadus, A., 2008. Toxicity of lithium to humans and the environment-A literature review. Ecotoxicology and Environmental Safety 70(3), 349-356.

Astley, O.M., Chanliaud, E., Donald, A.M., Gidley, M.J., 2001. Structure of Acetobacter cellulose composites in the hydrated state. International Journal of Biological Macromolecules 29(3), 193202.

Astley, O.M., Chanliaud, E., Donald, A.M., Gidley, M.J., 2003. Tensile deformation of bacterial cellulose composites. International Journal of Biological Macromolecules 32(1), 28-35.

Atalla, R.H., Vanderhart, D.L., 1984. Native cellulose: a composite of two distinct crystalline forms. Science 223(4633), 283-285.

Aydogdu, M.O., Altun, E., Crabbe-Mann, M., Brako, F., Koc, F., Ozen, G., Kuruca, S.E., Edirisinghe, U., Luo, C.J., 2018. Cellular interactions with bacterial cellulose: Polycaprolactone nanofibrous scaffolds produced by a portable electrohydrodynamic gun for point-of-need wound dressing. International Wound Journal 15(5), 789-797.

Aydogdu, M.O., Altun, E., Crabbe-Mann, M., Brako, F., Koc, F., Ozen, G., Kuruca, S.E., Edirisinghe, U., Luo, C.J., Gunduz, O., Edirisinghe, M., 2018. Cellular interactions with bacterial cellulose: 
929 Polycaprolactone nanofibrous scaffolds produced by a portable electrohydrodynamic gun for 930 point-of-need wound dressing. International Wound Journal 15(5), 789-797.

931 Aydogdu, O.M., Altun, E., Ahmed, J., Gunduz, O., Edirisinghe, M., 2019. Fiber Forming Capability 932 of Binary and Ternary Compositions in the Polymer System: Bacterial Cellulose933 Polycaprolactone-Polylactic Acid. Polymers 11(7), 1148.

934 Azarniya, A., Tamjid, E., Eslahi, N., Simchi, A., 2019. Modification of bacterial cellulose/keratin 935 nanofibrous mats by a tragacanth gum-conjugated hydrogel for wound healing. International Journal of Biological Macromolecules 134, 280-289.

Bäckdahl, H., Esguerra, M., Delbro, D., Risberg, B., Gatenholm, P., 2008. Engineering microporosity in bacterial cellulose scaffolds. Journal of Tissue Engineering and Regenerative Medicine 2(6), 320-330.

Bäckdahl, H., Helenius, G., Bodin, A., Nannmark, U., Johansson, B.R., Risberg, B., Gatenholm, P., 2006. Mechanical properties of bacterial cellulose and interactions with smooth muscle cells. Biomaterials 27(9), 2141-2149.

Bercea, M., Navard, P., 2000. Shear Dynamics of Aqueous Suspensions of Cellulose Whiskers. Macromolecules 33(16), 6011-6016.

Bernardo, E.B., Neilan, B.A., Couperwhite, I., 1998. Characterization, Differentiation and Identification of Wild-type Cellulose-synthesizing Acetobacter strains Involved in Nata de Coco Production. Systematic and Applied Microbiology 21(4), 599-608.

Bielecki, S., Krystynowicz, A., Turkiewicz, M., Kalinowska, H., 2005. Bacterial Cellulose, Biopolymers Online. Wiley-VCH Verlag GmbH \& Co. KGaA, pp. 40-43.

Boateng, J.S., Matthews, K.H., Stevens, H.N.E., Eccleston, G.M., 2008. Wound Healing Dressings and Drug Delivery Systems: A Review. Journal of Pharmaceutical Sciences 97(8), 2892-2923.

Brown, A.J., 1886. XLIII.-On an acetic ferment which forms cellulose. Journal of the Chemical Society, Transactions 49, 432-439.

Brown, R.M., Willison, J.H., Richardson, C.L., 1976. Cellulose biosynthesis in Acetobacter xylinum: visualization of the site of synthesis and direct measurement of the in vivo process. Proceedings of the National Academy of Sciences of the United States of America 73(12), 4565-4569.

Budhiono, A., Rosidi, B., Taher, H., Iguchi, M., 1999. Kinetic aspects of bacterial cellulose formation in nata-de-coco culture system. Carbohydrate Polymers 40(2), 137-143.

Çakar, F., Özer, I., Aytekin, A.Ö., Şahin, F., 2014. Improvement production of bacterial cellulose by semi-continuous process in molasses medium. Carbohydrate Polymers 106(Supplement C), 713.

Carvalho, T., Guedes, G., Sousa, F.L., Freire, C.S.R., Santos, H.A., 2019. Latest advances on bacterial cellulose-based materials for wound healing, delivery systems, and tissue engineering. Biotechnology Journal 14(12), 1900059.

Chao, Y., Ishida, T., Sugano, Y., Shoda, M., 2000. Bacterial cellulose production by Acetobacter xylinum in a 50-L internal-loop airlift reactor. Biotechnol Bioeng 68(3), 345-352.

Chen, G., Dong, C., Yang, L., Lv, Y., 2015. 3D scaffolds with different stiffness but the same microstructure for bone tissue engineering. ACS Applied Materials \& Interfaces 7(29), 1579015802.

Chen, P., Soo Yun, Y., Bak, H., Cho, S., Jin, H.-J., 2010. Multiwalled carbon nanotubes-embedded electrospun bacterial cellulose nanofibers. Taylor \& Francis online.

Ciechańska, D., 2004. Multifunctional bacterial cellulose/chitosan composite materials for medical applications. Fibres and Textiles in Eastern Europe 12(4), 69-72.

Curtis, A., Wilkinson, C., 1997. Topographical control of cells. Biomaterials 18(24), 1573-1583.

Czaja, W., Krystynowicz, A., Bielecki, S., Brown, R.M., Jr., 2006. Microbial cellulose-the natural power to heal wounds. Biomaterials 27(2), 145-151.

Czaja, W., Romanovicz, D., Brown, R.m., 2004. Structural investigations of microbial cellulose produced in stationary and agitated culture. Cellulose 11(3), 403-411. 
979 Czaja, W.K., Young, D.J., Kawecki, M., Brown, R.M., Jr., 2007. The future prospects of microbial 980 cellulose in biomedical applications. Biomacromolecules 8(1), 1-12.

981 De Wulf, P., Joris, K., Vandamme, E.J., 1996. Improved cellulose formation by an Acetobacter 982 xylinum mutant limited in (keto)gluconate synthesis. Journal of Chemical Technology \& 983 Biotechnology 67(4), 376-380.

984 Deitzel, J.M., Kleinmeyer, J., Harris, D., Beck Tan, N.C., 2001. The effect of processing variables on 985 the morphology of electrospun nanofibers and textiles. Polymer 42(1), 261-272.

986 Diegelmann, R.F., Evans, M.C., 2004. Wound healing: an overview of acute, fibrotic and delayed healing. Frontiers in Bioscience : A Journal and Virtual Library 9, 283-289.

Dobre, L., Stoica, A., M, S., Jinga, S., Jipa, I., Dobre, T., 2010. Characterization of composite materials based on biocellulose membranes impregnated with silver particles as antimicrobial agent. UPB Scientific Bulletin, Series B: Chemistry and Materials Science 72(4).

Dudman, W.F., 1960. Cellulose production by Acetobacter strains in submerged culture. J Gen Microbiol 22, 25-39.

Dufresne, A., 2000. Dynamic mechanical analysis of the interphase in bacterial polyester/cellulose whiskers natural composites. Composite Interfaces 7(1), 53-67.

Esa, F., Tasirin, S.M., Rahman, N.A., 2014. Overview of bacterial cellulose production and application. Agriculture and Agricultural Science Procedia 2(Supplement C), 113-119.

Eslahi, N., Mahmoodi, A., Mahmoudi, N., Zandi, N., Simchi, A., 2020. Processing and properties of nanofibrous bacterial cellulose-containing polymer composites: A review of recent advances for biomedical applications. Polymer Reviews 60(1), 144-170.

Favier, V., Cavaille, J.Y., Canova, G.R., Shrivastava, S.C., 1997. Mechanical percolation in cellulose whisker nanocomposites. Polymer Engineering \& Science 37(10), 1732-1739.

Feng, J.J., 2002. The stretching of an electrified non-Newtonian jet: A model for electrospinning. Physics of Fluids 14(11), 3912-3926.

Feng, L., Li, S., Li, Y., Li, H., Zhang, L., Zhai, J., Song, Y., Liu, B., Jiang, L., Zhu, D., 2002. Superhydrophobic surfaces: from natural to artificial. Advanced Materials 14(24), 1857-1860.

Fleck, C.A., Simman, R., 2010. Modern collagen wound dressings: function and purpose. The journal of the American College of Certified Wound Specialists 2(3), 50-54.

Fong, H., Chun, I., Reneker, D.H., 1999. Beaded nanofibers formed during electrospinning. Polymer 40(16), 4585-4592.

Fontana, J.D., De Souza, A.M., Fontana, C.K., Torriani, I.L., Moreschi, J.C., Gallotti, B.J., De Souza, S.J., Narcisco, G.P., Bichara, J.A., Farah, L.F.X., 1990. Acetobacter cellulose pellicle as a temporary skin substitute. Applied Biochemistry and Biotechnology 24(1), 253-264.

Frederick, W.J., Lien, S.J., Courchene, C.E., DeMartini, N.A., Ragauskas, A.J., lisa, K., 2008. Coproduction of ethanol and cellulose fiber from Southern Pine: A technical and economic assessment. Biomass and Bioenergy 32(12), 1293-1302.

Fu, L., Zhang, J., Yang, G., 2013. Present status and applications of bacterial cellulose-based materials for skin tissue repair. Carbohydrate Polymers 92(2), 1432-1442.

Gallegos, A.M.A., Carrera, S.H., Parra, R., Keshavarz, T., Iqbal, H.M.J.B., 2016. Bacterial cellulose: A sustainable source to develop value-added products-A review. BioResources 11(2), 5641-5655. Gea, S., Reynolds, C.T., Roohpour, N., Wirjosentono, B., Soykeabkaew, N., Bilotti, E., Peijs, T., 2011. Investigation into the structural, morphological, mechanical and thermal behaviour of bacterial cellulose after a two-step purification process. Bioresource Technology 102(19), 91059110.

1024 Gelin, K., Bodin, A., Gatenholm, P., Mihranyan, A., Edwards, K., Strømme, M., 2007. 1025 Characterization of water in bacterial cellulose using dielectric spectroscopy and electron 1026 microscopy. Polymer 48(26), 7623-7631.

1027 Gindl, W., Keckes, J., 2004. Tensile properties of cellulose acetate butyrate composites reinforced 1028 with bacterial cellulose. Composites Science and Technology 64(15), 2407-2413. 
Gould, L., Abadir, P., Brem, H., Carter, M., Conner-Kerr, T., Davidson, J., DiPietro, L., Falanga, V., Fife, C., Gardner, S., Grice, E., Harmon, J., Hazzard, W.R., High, K.P., Houghton, P., Jacobson, N., Kirsner, R.S., Kovacs, E.J., Margolis, D., McFarland Horne, F., Reed, M.J., Sullivan, D.H., Thom, S., Tomic-Canic, M., Walston, J., Whitney, J.A., Williams, J., Zieman, S., Schmader, K., 2015. Chronic wound repair and healing in older adults: current status and future research. J Am Geriatr Soc 63(3), 427-438.

Guhados, G., Wan, W., Hutter, J.L., 2005. Measurement of the elastic modulus of single bacterial cellulose fibers using atomic force microscopy. Langmuir 21(14), 6642-6646.

Haase, J., Hosemann, R., Renwanz, B., 1974. X-ray wide and small angle X-ray examinations on cellulose. Colloid and Polymer Science 252(9), 712-717.

Helenius, G., Backdahl, H., Bodin, A., Nannmark, U., Gatenholm, P., Risberg, B., 2006. In vivo biocompatibility of bacterial cellulose. Journal of Biomedical Materials Research. Part A 76(2), 431-438.

Heseltine, P.L., Ahmed, J., Edirisinghe, M., 2018. Developments in pressurized gyration for the mass production of polymeric fibers. Macromolecular Materials and Engineering 1800218.

Hestrin, S., Schramm, M., 1954. Synthesis of cellulose by Acetobacter xylinum. 2. Preparation of freeze-dried cells capable of polymerizing glucose to cellulose. Biochemical Journal 58(2), 345352.

Hibbert, H., 1930. Action of bacteria and enzymes on carbohydrates and their bearing on plant synthesis. Science 71(1842), 419.

Hu, W., Chen, S., Yang, J., Li, Z., Wang, H., 2014. Functionalized bacterial cellulose derivatives and nanocomposites. Carbohydrate Polymers 101(Supplement C), 1043-1060.

Hu, Y., Catchmark, J.M., 2011. In vitro biodegradability and mechanical properties of bioabsorbable bacterial cellulose incorporating cellulases. Acta Biomaterilia 7(7), 2835-2845.

Hussain, Z., Sajjad, W., Khan, T., Wahid, F.J.C., 2019. Production of bacterial cellulose from industrial wastes: a review. Cellulose 26(5), 2895-2911.

Iguchi, M., Yamanaka, S., Budhiono, A., 2000. Bacterial cellulose-a masterpiece of nature's arts. Journal of Materials Science 35(2), 261-270.

J Grande, C., Torres, F., Gómez, C., Troncoso Heros, O., Canet-Ferrer, J., Martinez-Pastor, J., 2008. Morphological characterisation of bacterial cellulose-starch nanocomposites. Polymers and Polymer Composites 16(4), 181-185.

Jagannath, A., Kalaiselvan, A., Manjunatha, S.S., Raju, P.S., Bawa, A.S., 2008. The effect of pH, sucrose and ammonium sulphate concentrations on the production of bacterial cellulose (Natade-coco) by Acetobacter xylinum. World Journal of Microbiology and Biotechnology 24(11), 2593. Jelenko, C.r., Smulyan, W.I., Wheeler, M.L., 1968. Studies in burns: the role of lipids in the transmissivity of membranes. Annals of Surgery 167(4), 521-532.

Johnson, D.C., Neogi, A.N., LeBlanc, H.A., 1989. Bacterial cellulose as surface treatment for fibrous web. CP Kelco US Inc Weyerhaeuser Co.

Jonas, R., Farah, L.F., 1998. Production and application of microbial cellulose. Polymer Degradation and Stability 59(1), 101-106.

Jones, I., Currie, L., Martin, R., 2002. A guide to biological skin substitutes. British Journal of Plastic Surgery 55(3), 185-193.

Jung, J.Y., Park, J.K., Chang, H.N., 2005. Bacterial cellulose production by Gluconacetobacter hansenii in an agitated culture without living non-cellulose producing cells. Enzyme and Microbial Technology 37(3), 347-354.

Kaewnopparat, S., Sansernluk, K., Faroongsarng, D., 2008. Behavior of freezable bound water in the bacterial cellulose produced by Acetobacter xylinum: An approach using thermoporosimetry. AAPS PharmSciTech 9(2), 701-707.

Kamide, K., Matsuda, Y., lijima, H., Okajima, K., 1990. Effect of culture conditions of acetic acid bacteria on cellulose biosynthesis. British Polymer Journal 22(2), 167-171. 
1079 Kim, J.-S., Reneker, D.H., 1999. Polybenzimidazole nanofiber produced by electrospinning.

1080 Polymer Engineering \& Science 39(5), 849-854.

1081 Kim, J., Cai, Z., Lee, H.S., Choi, G.S., Lee, D.H., Jo, C., 2011. Preparation and characterization of a 1082 Bacterial cellulose/Chitosan composite for potential biomedical application. Journal of Polymer 1083 Research 18(4), 739-744.

1084 Klemm, D., Schumann, D., Udhardt, U., Marsch, S., 2001. Bacterial synthesized cellulose-artificial 1085 blood vessels for microsurgery. Progress in Polymer Science 26(9), 1561-1603.

1086 Kosmider, K., Scott, J., 2002. Polymeric nanofibres exhibit an enhanced air filtration performance. 1087 Filtration \& Separation 39(6), 20-22.

1088 Kouda, T., Yano, H., Yoshinaga, F., 1997. Effect of agitator configuration on bacterial cellulose 1089 productivity in aerated and agitated culture. Journal of Fermentation and Bioengineering 83(4), 1090 371-376.

1091 Kouda, T., Yano, H., Yoshinaga, F., Kaminoyama, M., Kamiwano, M., 1996. Characterization of 1092 1093 1094 1095 1096 1097 1098 1099

1100

1101

1102

1103

1104

1105

1106

1107

1108

1109

1110

1111

1112

1113

1114

1115

1116

1117

1118

1119

1120 non-newtonian behavior during mixing of bacterial cellulose in a bioreactor. Journal of Fermentation and Bioengineering 82(4), 382-386.

Kouhi, M., Jayarama Reddy, V., Fathi, M., Shamanian, M., Valipouri, A., Ramakrishna, S., 2019. Poly (3-hydroxybutyrate-co-3-hydroxyvalerate)/fibrinogen/bredigite nanofibrous membranes and their integration with osteoblasts for guided bone regeneration. Journal of Biomedical Materials Research Part A 107(6), 1154-1165.

Krystynowicz, A., 1997. Method of bacterial cellulose production, Sposob wytwarzania celulozy bakteryjnej. Patent PL. World Intellectual Property Organisation Poland.

Krystynowicz, A., Czaja, W., Wiktorowska-Jezierska, A., Gonçalves-Miśkiewicz, M., Turkiewicz, M., Bielecki, S., 2002. Factors affecting the yield and properties of bacterial cellulose. Journal of Industrial Microbiology and Biotechnology 29(4), 189-195.

Laçin, N.T., 2014. Development of biodegradable antibacterial cellulose based hydrogel membranes for wound healing. International Journal of Biological Macromolecules 67, 22-27.

Lamke, L.O., Nilsson, G.E., Reithner, H.L., 1977. The evaporative water loss from burns and the water-vapour permeability of grafts and artificial membranes used in the treatment of burns. Burns 3(3), 159-165.

Łaskiewicz, B., 1998. Solubility of bacterial cellulose and its structural properties. Journal of Applied Polymer Science 67(11), 1871-1876.

Lee, S.E., Park, Y.S., 2017. The role of bacterial cellulose in artificial blood vessels. Molecular \& Cellular Toxicology 13(3), 257-261.

Li, J., Wan, Y., Li, L., Liang, H., Wang, J., 2009. Preparation and characterization of 2,3-dialdehyde bacterial cellulose for potential biodegradable tissue engineering scaffolds. Materials Science and Engineering: C 29(5), 1635-1642.

Lin, S.-B., Hsu, C.-P., Chen, L.-C., Chen, H.-H., 2009. Adding enzymatically modified gelatin to enhance the rehydration abilities and mechanical properties of bacterial cellulose. Food Hydrocolloids 23(8), 2195-2203.

Lin, W.-C., Lien, C.-C., Yeh, H.-J., Yu, C.-M., Hsu, S.-h., 2013. Bacterial cellulose and bacterial cellulose-chitosan membranes for wound dressing applications. Carbohydrate Polymers 94(1), 603-611.

1121 Lu, X., Shen, X., 2011. Solubility of bacteria cellulose in zinc chloride aqueous solutions. 1122 Carbohydrate Polymers 86(1), 239-244.

1123 Luo, C.J., Stoyanov, S.D., Stride, E., Pelan, E., Edirisinghe, M., 2012. Electrospinning versus fibre 1124 production methods: from specifics to technological convergence. Chem Soc Rev 41(13), 470811254735.

1126 Mahalingam, S., Edirisinghe, M., 2013. Forming of polymer nanofibers by a pressurised gyration 1127 process. Macromolecular Rapid Communications 34(14), 1134-1139. 
Marins, J.A., Soares, B.G., Dahmouche, K., Ribeiro, S.J.L., Barud, H., Bonemer, D., 2011. Structure and properties of conducting bacterial cellulose-polyaniline nanocomposites. Cellulose 18(5), 1285-1294.

Martin, P., 1997. Wound healing-aiming for perfect skin regeneration. Science 276(5309), 75. Martínez-Sanz, M., Olsson, R.T., Lopez-Rubio, A., Lagaron, J.M., 2011. Development of electrospun EVOH fibres reinforced with bacterial cellulose nanowhiskers. Part I: Characterization and method optimization. Cellulose 18(2), 335-347.

Mikkelsen, D., Flanagan, B.M., Dykes, G.A., Gidley, M.J., 2009. Influence of different carbon sources on bacterial cellulose production by Gluconacetobacter xylinus strain ATCC 53524 . Journal of Applied Microbiology 107(2), 576-583.

Mikkelsen, M.D., Harholt, J., Ulvskov, P., Johansen, I.E., Fangel, J.U., Doblin, M.S., Bacic, A., Willats, W.G., 2014. Evidence for land plant cell wall biosynthetic mechanisms in charophyte green algae. Annals of Botany 114(6), 1217-1236.

Miyamoto, T., Takahashi, S.-i., Ito, H., Inagaki, H., Noishiki, Y., 1989. Tissue biocompatibility of cellulose and its derivatives. Journal of Biomedical Materials Research 23(1), 125-133.

Mohd Amin, M.C.I., Ahmad, N., Halib, N., Ahmad, I., 2012. Synthesis and characterization of thermo- and $\mathrm{pH}$-responsive bacterial cellulose/acrylic acid hydrogels for drug delivery. Carbohydrate Polymers 88(2), 465-473.

Monaco, G., Cholas, R., Salvatore, L., Madaghiele, M., Sannino, A., 2017. Sterilization of collagen scaffolds designed for peripheral nerve regeneration: Effect on microstructure, degradation and cellular colonization. Materials Science \& Engineering. C, Materials for Biological Applications 71, 335-344.

Moreira, S., Silva, N.B., Almeida-Lima, J., Rocha, H.A., Medeiros, S.R., Alves, C., Jr., Gama, F.M., 2009. BC nanofibres: in vitro study of genotoxicity and cell proliferation. Toxicol Lett 189(3), 235241.

Morgenstern, B., Berger, W., 1993. Investigations about dissolution of cellulose in the $\mathrm{LiCl} / \mathrm{N}, \mathrm{N}-$ dimethylformamide system. Acta Polymerica 44(2), 100-102.

Nakayama, A., Kakugo, A., Gong, J.P., Osada, Y., Takai, M., Erata, T., Kawano, S., 2004. High mechanical strength double-network hydrogel with bacterial cellulose. Advanced Functional Materials 14(11), 1124-1128.

Naritomi, T., Kouda, T., Yano, H., Yoshinaga, F., 1998a. Effect of ethanol on bacterial cellulose production from fructose in continuous culture. Journal of Fermentation and Bioengineering 85(6), 598-603.

Naritomi, T., Kouda, T., Yano, H., Yoshinaga, F., 1998b. Effect of lactate on bacterial cellulose production from fructose in continuous culture. Journal of Fermentation and Bioengineering 85(1), 89-95.

Nishi, Y., Uryu, M., Yamanaka, S., Watanabe, K., Kitamura, N., Iguchi, M., Mitsuhashi, S., 1990. The structure and mechanical properties of sheets prepared from bacterial cellulose. Journal of Materials Science 25(6), 2997-3001.

Nishino, T., Takano, K., Nakamae, K., 1995. Elastic modulus of the crystalline regions of cellulose polymorphs. Journal of Polymer Science Part B: Polymer Physics 33(11), 1647-1651.

Park, W.-I., Kang, M., Kim, H.-S., Jin, H.-J., 2007. Electrospinning of poly(ethylene oxide) with bacterial cellulose whiskers. Macromolecular Symposia 249-250(1), 289-294.

Peggy O'Neill, S., Cannon, R.E., 2000. Acetobacter xylinum: An inquiry into cellulose biosynthesis. The American Biology Teacher 62(6), 442-444.

Pertile, R.A.N., Andrade, F.K., Alves, C., Gama, M., 2010. Surface modification of bacterial cellulose by nitrogen-containing plasma for improved interaction with cells. Carbohydrate Polymers 82(3), 692-698.

Phisalaphong, M., Suwanmajo, T., Sangtherapitikul, P., 2008. Novel nanoporous membranes from regenerated bacterial cellulose. Journal of Applied Polymer Science 107(1), 292-299. 
Picheth, G.F., Pirich, C.L., Sierakowski, M.R., Woehl, M.A., Sakakibara, C.N., de Souza, C.F., Martin, A.A., da Silva, R., de Freitas, R.A., 2017. Bacterial cellulose in biomedical applications: A review. International Journal of Biological Macromolecules 104, 97-106.

Pommet, M., Juntaro, J., Heng, J.Y.Y., Mantalaris, A., Lee, A.F., Wilson, K., Kalinka, G., Shaffer, M.S.P., Bismarck, A., 2008. Surface modification of natural fibers using bacteria: depositing bacterial cellulose onto natural fibers to create hierarchical fiber reinforced nanocomposites. Biomacromolecules 9(6), 1643-1651.

Portela, R., Leal, C.R., Almeida, P.L., Sobral, R.G., 2019. Bacterial cellulose: a versatile biopolymer for wound dressing applications. Microbial Biotechnology 12(4), 586-610.

Posnett, J., Gottrup, F., Lundgren, H., Saal, G., 2009. The resource impact of wounds on healthcare providers in Europe. Journal of Wound Care 18(4), 154-161.

Qin, Z., Ji, L., Yin, X., Zhu, L., Lin, Q., Qin, J., 2014. Synthesis and characterization of bacterial cellulose sulfates using a SO3/pyridine complex in DMAc/LiCl. Carbohydrate Polymers 101(Supplement C), 947-953.

R. Chawla, P., Bajaj, I., Survase, S., S. Singhal, R., 2009. Microbial cellulose: fermentative production and applications. Food Technology and Biotechnology 47(2):107-124.

Rangaswamy, B.E., Vanitha, K.P., Hungund, B.S., 2015. Microbial cellulose production from bacteria isolated from rotten fruit. International Journal of Polymer Science 2015, 8.

Ring, D.F., Nashed, W., Dow, T., 1986a. Liquid loaded pad for medical applications. Johnson \& Johnson Patient Care Inc.

Ring, D.F., Nashed, W., Dow, T., 1986b. Microbial polysaccharide articles and methods of production. Johnson \& Johnson Products Inc. .

Rodan, S.B., Imai, Y., Thiede, M.A., Wesolowski, G., Thompson, D., Bar-Shavit, Z., Shull, S., Mann, K., Rodan, G.A., 1987. Characterization of a human osteosarcoma cell line (Saos-2) with osteoblastic properties. Cancer Research 47(18), 4961-4966.

Rohrling, J., Potthast, A., Rosenau, T., Lange, T., Borgards, A., Sixta, H., Kosma, P., 2002. A novel method for the determination of carbonyl groups in cellulosics by fluorescence labeling. 2 . Validation and applications. Biomacromolecules 3(5), 969-975.

Ross, P., Mayer, R., Benziman, M., 1991. Cellulose biosynthesis and function in bacteria. Microbiological Reviews 55(1), 35-58.

Ross, P., Mayer, R., Weinhouse, H., Amikam, D., Huggirat, Y., Benziman, M., de Vroom, E., Fidder, A., de Paus, P., Sliedregt, L.A., 1990. The cyclic diguanylic acid regulatory system of cellulose synthesis in Acetobacter xylinum. Chemical synthesis and biological activity of cyclic nucleotide dimer, trimer, and phosphothioate derivatives. Journal of Biological Chemistry 265(31), 1893318943.

Sachlos, E., Czernuszka, J.T., 2003. Making tissue engineering scaffolds work. Review: the application of solid freeform fabrication technology to the production of tissue engineering scaffolds. European Cells \& Materials 5, 29-39; discussion 39-40.

Schlufter, K., Schmauder, H.-P., Dorn, S., Heinze, T., 2006. Efficient homogeneous chemical modification of bacterial cellulose in the ionic liquid 1-N-butyl-3-methylimidazolium chloride. Macromolecular Rapid Communications 27(19), 1670-1676.

Schramm, M., Hestrin, S., 1954. Factors affecting production of cellulose at the air/liquid interface of a culture of Acetobacter xylinum. J Gen Microbiol 11(1), 123-129.

Schrecker, S.T., Gostomski, P.A., 2005. Determining the water holding capacity of microbial cellulose. Biotechnology Letters 27(19), 1435-1438.

Shen, X., Ji, Y., Wang, D., Yang, Q., 2010. Solubility of a high molecular-weight bacterial cellulose in lithium chloride/N,N-dimethylacetamide solution. Journal of Macromolecular Science, Part B Physics 49(5), 1012-1018.

Shezad, O., Khan, S., Khan, T., Park, J.K., 2010. Physicochemical and mechanical characterization of bacterial cellulose produced with an excellent productivity in static conditions using a simple fed-batch cultivation strategy. Carbohydrate Polymers 82(1), 173-180. 
Shibazaki, H., Kuga, S., Onabe, F., Usuda, M., 1993. Bacterial cellulose membrane as separation medium. Journal of Applied Polymer Science 50(6), 965-969.

Shoda, M., Sugano, Y., 2005. Recent advances in bacterial cellulose production. Biotechnology and Bioprocess Engineering 10(1), 1.

Sofokleous, P., Stride, E., Bonfield, W., Edirisinghe, M., 2013. Design, construction and performance of a portable handheld electrohydrodynamic multi-needle spray gun for biomedical applications. Materials Science and Engineering: C 33(1), 213-223.

Song, H.-J., Li, H., Seo, J.-H., Kim, M.-J., Kim, S.-J., 2009. Pilot-scale production of bacterial cellulose by a spherical type bubble column bioreactor using saccharified food wastes. Korean Journal of Chemical Engineering 26(1), 141-146.

Stock, U.A., Vacanti, J.P., 2001. Tissue engineering: Current state and prospects. Annual Review of Medicine 52(1), 443-451.

Sulaeva, I., Henniges, U., Rosenau, T., Potthast, A., 2015. Bacterial cellulose as a material for wound treatment: Properties and modifications. A review. Biotechnology Advances 33(8), 15471571.

Svensson, A., Nicklasson, E., Harrah, T., Panilaitis, B., Kaplan, D.L., Brittberg, M., Gatenholm, P., 2005. Bacterial cellulose as a potential scaffold for tissue engineering of cartilage. Biomaterials 26(4), 419-431.

Thomas, S., 2008. A review of the physical, biological and clinical properties of a bacterial cellulose wound. Journal of Wound Care 17(8), 349-352.

Torres, G.F., Commeaux, S., Troncoso, P.O., 2012. Biocompatibility of bacterial cellulose based biomaterials. Journal of Functional Biomaterials 3(4).

Tsuchida, T., Yoshinaga, F., 1997. Production of bacterial cellulose by agitation culture systems. Pure and Applied Chemistry. p. 2453.

UI-Islam, M., Khan, T., Park, J.K., 2012. Water holding and release properties of bacterial cellulose obtained by in situ and ex situ modification. Carbohydrate Polymers 88(2), 596-603.

United, S., Congress, 1993. Biopolymers : making materials nature's way. U.S Congress, Washington, DC.

van de Witte, P., Esselbrugge, H., Peters, A.M.P., Dijkstra, P.J., Feijen, J., Groenewegen, R.J.J., Smid, J., Olijslager, J., Schakenraad, J.M., Eenink, M.J.D., Sam, A.P., 1993. Formation of porous membranes for drug delivery systems. Journal of Controlled Release 24(1), 61-78.

Vandamme, E.J., De Baets, S., Vanbaelen, A., Joris, K., De Wulf, P., 1998. Improved production of bacterial cellulose and its application potential. Polymer Degradation and Stability 59(1), 93-99. VanderHart, D.L., Atalla, R.H., 1984. Studies of microstructure in native celluloses using solid-state carbon-13 NMR. Macromolecules 17(8), 1465-1472.

Wan, Y.Z., Luo, H., He, F., Liang, H., Huang, Y., Li, X.L., 2009. Mechanical, moisture absorption, and biodegradation behaviours of bacterial cellulose fibre-reinforced starch biocomposites. Composites Science and Technology 69(7), 1212-1217.

Wang, J., Tavakoli, J., Tang, Y., 2019. Bacterial cellulose production, properties and applications with different culture methods - A review. Carbohydrate Polymers 219, 63-76.

Wang, Y., Wang, G., Luo, X., Qiu, J., Tang, C., 2012. Substrate stiffness regulates the proliferation, migration, and differentiation of epidermal cells. Burns 38(3), 414-420.

Watanabe, K., Tabuchi, M., Morinaga, Y., Yoshinaga, F., 1998. Structural features and properties of bacterial cellulose produced in agitated culture. Cellulose 5(3), 187-200.

Weinhouse, H., Benziman, M., 1974. Regulation of hexose phosphate metabolism in Acetobacter xylinum. Biochem J 138(3), 537-542.

Wu, J., Zheng, Y., Yang, Z., Lin, Q., Qiao, K., Chen, X., Peng, Y., 2014. Influence of dialdehyde bacterial cellulose with the nonlinear elasticity and topology structure of ECM on cell adhesion and proliferation. RSC Advances 4(8), 3998-4009.

Xu, R., Xia, H., He, W., Li, Z., Zhao, J., Liu, B., Wang, Y., Lei, Q., Kong, Y., Bai, Y., Yao, Z., Yan, R., Li, H., Zhan, R., Yang, S., Luo, G., Wu, J., 2016. Controlled water vapor transmission rate promotes 
wound-healing via wound re-epithelialization and contraction enhancement. Scientific Reports 6 ,

128124596.

1282 Yamamoto, H., Horii, F., 1993. CPMAS carbon-13 NMR analysis of the crystal transformation 1283 induced for Valonia cellulose by annealing at high temperatures. Macromolecules 26(6), 131312841317.

1285 Yamanaka, S., Sugiyama, J., 2000. Structural modification of bacterial cellulose. Cellulose 7(3), 1286 213-225.

1287 Yamanaka, S., Watanabe, K., Kitamura, N., Iguchi, M., Mitsuhashi, S., Nishi, Y., Uryu, M., 1989. 1288 The structure and mechanical properties of sheets prepared from bacterial cellulose. Journal of 1289 Materials Science 24(9), 3141-3145.

1290 Yan, Z., Chen, S., Wang, H., Wang, B., Jiang, J., 2008. Biosynthesis of bacterial cellulose/multi1291 walled carbon nanotubes in agitated culture. Carbohydrate Polymers 74(3), 659-665.

1292 Yano, H., Sugiyama, J., Nakagaito, A., Nogi, M., Matsuura, T., Hikita, M., Handa, K., 2005. Optically 1293 transparent composites reinforced with networks of bacterial nanofibers. Advanced Materials 1294 17(2), 153-155.

1295 Yano, S., Maeda, H., Nakajima, M., Hagiwara, T., Sawaguchi, T., 2008. Preparation and mechanical 1296 1297 properties of bacterial cellulose nanocomposites loaded with silica nanoparticles. Cellulose 15(1), 111-120.

1300 Yoshinaga, F., Tonouchi, N., Watanabe, K., 1997. Research progress in production of bacterial 1301 cellulose by aeration and agitation culture and its application as a new industrial material. 1302 Bioscience, Biotechnology, and Biochemistry 61(2), 219-224.

1303 Young, R.J., Lu, D., Day, R.J., Knoff, W.F., Davis, H.A., 1992. Relationship between structure and 1304 mechanical properties for aramid fibres. Journal of Materials Science 27(20), 5431-5440.

1305 Yuyang, L., Xianqiong, C., Xin, J.H., 2006. Super-hydrophobic surfaces from a simple coating 1306 method: a bionic nanoengineering approach. Nanotechnology 17(13), 3259.

1307 Zaar, K., 1977. The biogenesis of cellulose by Acetobacter xylinum. Cytobiologie 16, 1-15.

1308 Zaar, K., 1979. Visualization of pores (export sites) correlated with cellulose production in the 1309 envelope of the gram-negative bacterium Acetobacter xylinum. J Cell Biol 80(3), 773-777.

1310 Zhang, C., Shao, Y., Zhu, L., Wang, J., Wang, J., Guo, Y., 2017. Acute toxicity, biochemical toxicity 1311 and genotoxicity caused by 1-butyl-3-methylimidazolium chloride and 1-butyl-31312 methylimidazolium tetrafluoroborate in zebrafish (Danio rerio) livers. Environmental Toxicology 1313 and Pharmacology 51, 131-137. 
1 Bacterial Cellulose Micro-Nano Fibres for Wound Healing 2 Applications

3 Jubair Ahmed ${ }^{1}$, Merve Gultekinoglu ${ }^{2}$ and Mohan Edirisinghe ${ }^{1 *}$.

$4{ }^{1}$ Department of Mechanical Engineering, University College London, London WC1E 7JE, 5 UK.

$6{ }^{2}$ Department of Basic Pharmaceutical Sciences, Faculty of Pharmacy, Hacettepe 7 University, Ankara 06100, Turkey

$8 \quad{ }^{*}$ Corresponding author: m.edirisinghe@ucl.ac.uk

\section{Abstract}

Bacterial cellulose $(\mathrm{BC})$ is cellulose produced by a few limited species of bacteria in given conditions. BC has many remarkable properties such as its high mechanical properties, water uptake ability and biocompatibility which makes it a very desirable material to be used for wound healing. Inherently due to these important properties, the material is very resistant to easy processing and thus difficult to produce into useful entities. Additionally, being rate limited by the dependency on bacterial production, high yield is difficult to obtain and thus secondary material processing is sought after. In this review, BC is explained in terms of synthesis, structure and properties. These beneficial properties are directly related to the material's great potential in wound healing where it has also been trialled commercially but ultimately failed due to processing issues. However, more recently there has been increased frequency in scientific work relating to BC processing into hybrid polymeric fibres using common laboratory fibre forming techniques such as electrospinning and pressurised gyration. This paper summarises current progress in $\mathrm{BC}$ fibre manufacturing, its downfalls and also gives a future perspective on how the landscape should change to allow $B C$ to be utilised in wound care in the current environment.

Keywords: Bacterial Cellulose, wound healing, fibres, Gluconacetobacter xylinum, fibre production

\section{Introduction}

As early as in the $19^{\text {th }}$ century A.J Brown, noted that a specific bacterium produced a solid membrane at the surface of his culture when grown in a carbohydrate-rich medium (Brown, 1886). Later studies demonstrated that the material of the membrane produced by these bacterial species were identical to the principle structural polysaccharide of plants, cellulose (Hibbert, 1930). In contrast to plant cellulose, the gelatinous membrane showed incredibly high strength, purity, porosity, a uniform fibre network and enhanced water holding ability (R. Chawla et al., 2009). The cellulose produced by the bacterial genera Gluconacetobacter (formerly Acetobacter) are commonly called bacterial cellulose (BC), which is in itself a biopolymer. Moreover, $\mathrm{BC}$ demonstrates the fascinating ability to enhance 
wound healing recovery, revealing the potential to revolutionise the healthcare market (Sulaeva et al., 2015). The cost of wound care for any healthcare provider marks a significant portion of overall expenditure. In hospitals, more than $30 \%$ of the beds are occupied by patients having wounds, some of whom who do not require to stay in the hospital for their main disorders (Posnett et al., 2009). With the rise in global average life expectancy, chronic wounds have shown strong correlation with increasing age (Gould et al., 2015).

There is a growing pressure for the development of advanced wound care that has capacity to meet the soaring demands. Although there is an abundance of literature on $\mathrm{BC}$ and its applications, there is little on the processing of $\mathrm{BC}$ into biomaterials for wound healing, especially in fibrous structures (Carvalho et al., 2019; Picheth et al., 2017; Thomas, 2008). This review focuses on the structure and properties of $\mathrm{BC}$, current progress on its processing for wound care applications and what is necessary to overcome in order to widely use this astonishing material in healthcare settings.

\section{Bacterial Cellulose (BC) Synthesis}

This cellulose is commonly referred to as "bacterial cellulose" or "microbial cellulose" which is found as a gelatinous membrane at the liquid-air interface of the culture medium (Kamide et al., 1990). BC is produced at certain culture conditions by a number of bacteria belonging to the genus: Achromobacter, Aerobacter, Agrobacterium, Alcaligenes, Azotobacter, Gluconacetobacter, Rhizobium and Salmonella (Rangaswamy et al., 2015). Yet, the gram negative Gluconacetobacter xylinum, has been primary focus in most BC related studies as the cellulose production is far greater in quantity and mass than the other strains, is of extraordinarily high purity and closely resembles that of algal and plant cellulose in its microfibrillar structure (Mikkelsen et al., 2014). Many strains of $G$. xylinum retain the ability to extracellularly produce cellulose in the form of flat, twisting ribbons. G. xylinum is an aerobic soil bacterium which belongs to a family of bacteria which are able to ferment carbohydrates into acetic acid (vinegar) (Peggy O'Neill and Cannon, 2000). 


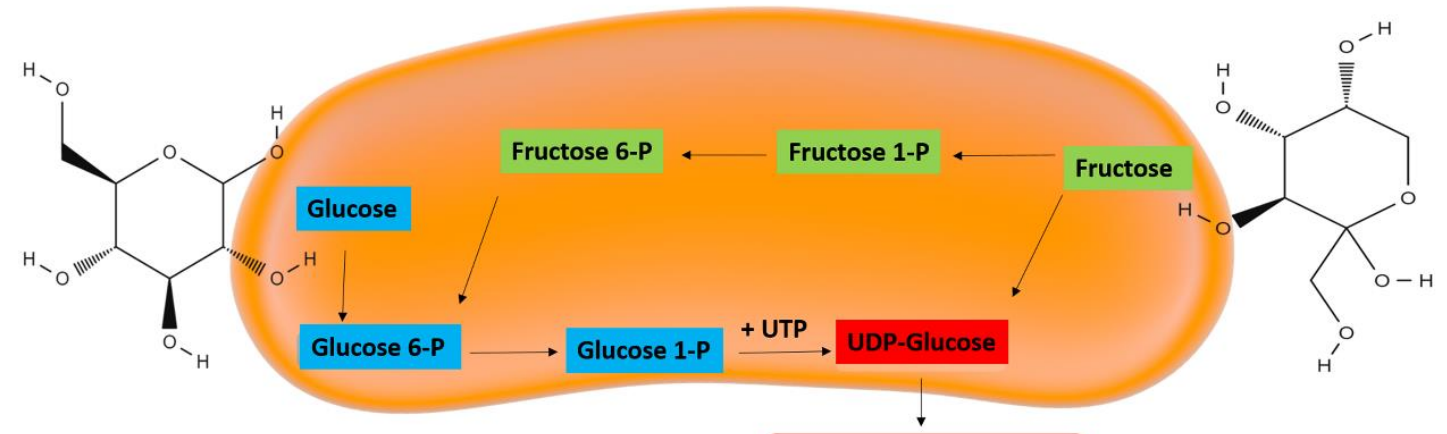

a)
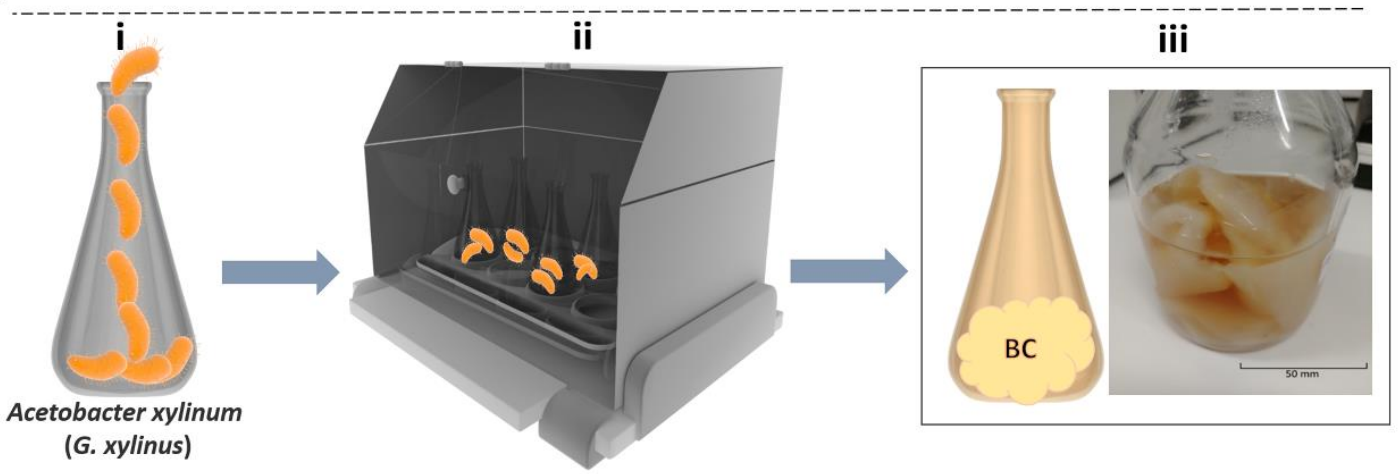

b)

Figure 1: Schematic diagrams of: a) BC fibrils synthesis reaction from glucose and fructose pathways. b) Schematic representation of BC synthesis (i) Acetobacter xylinum (G. xylinus), (ii) Acetobacter xylinum (G. xylinus) incubation, (iii) Photograph of bacterial cellulose (BC) gelatinous membrane encased within a 200 $\mathrm{mL}$ glass vial and suspended in acetic acid.

The synthesis of cellulose in G. xylinum occurs in a multi-step biochemical pathway of reactions beginning with glucose, which is catalysed by multiple enzymes. Cellulose synthesis is considered to be the most crucial enzyme in the $\mathrm{BC}$ production process and is responsible to the catalysis of the step preceding the final cellulose production (Ross et al., 1990). The commonly accepted pathway for cellulose production in G. xylinum cultures can be summarised as (Figure 1A): Glucose (catalysed by glucokinase) $\rightarrow$ Glucose-6-Phosphate (catalysed by phosphoglucomutase) $\rightarrow$ Glucose-1-Phosphate (catalysed by UDP-glucose pyrophosphorylase) $\rightarrow$ UDP-Glucose (catalysed by cellulose synthase) $\rightarrow$ Cellulose (Klemm et al., 2001).

A single cell of $G$. xylinum has been shown to be able to polymerise up to 200,000 glucose molecules per second into B-1,4-glucan chains (Hestrin and Schramm, 1954). These chains are extruded into the surrounding medium from the pole of the bacterial rod, which form a single ribbon-like bundle of microfibrils composed of single twisted strands (Ross et al., 1991). This ribbon elongates with the cell envelope at a rate of $2 \mu \mathrm{m}$ per minute and remains associated during cell division, at the liquid-air interface the suspensions continue with their microfibrillar projections for several hours, giving rise to a cellulosic pellicle (Brown et al., 1976). The fibrils of the ribbons are in close association with the pores longitudinally positioned in the bacterial cell membrane, cellulose biogenesis in G. xylinum is one of the best proven examples of unidirectional growth of cellulose microfibrils. 
(Zaar, 1979). A single cellulose fibril can be visualised as a cable where the lengthwise strands are D-glucose composed polymeric chains, each chain containing uniformly linked sugar monomers by $ß-1,4$ glycosidic bonds (Ross et al., 1991).

G. xylinum cultures are characterised as a thick glutinous cellulosic surface mat (Figure 2). This gelatinous membrane (pellicle) is where the embedded cells have direct contact with the liquid/air interface (Schramm and Hestrin, 1954). G. xylinum grows and forms cellulose in a range of carbon sources which include glucose, fructose and glycerol (Jonas and Farah, 1998; Mikkelsen et al., 2009; Weinhouse and Benziman, 1974). The growth, metabolism and cellulose production of this bacterium is free from cellulase activity which would otherwise break down the cellulose, this provides a distinct advantage over plant cellulose by being metabolically inert and highly pure (Vandamme et al., 1998).

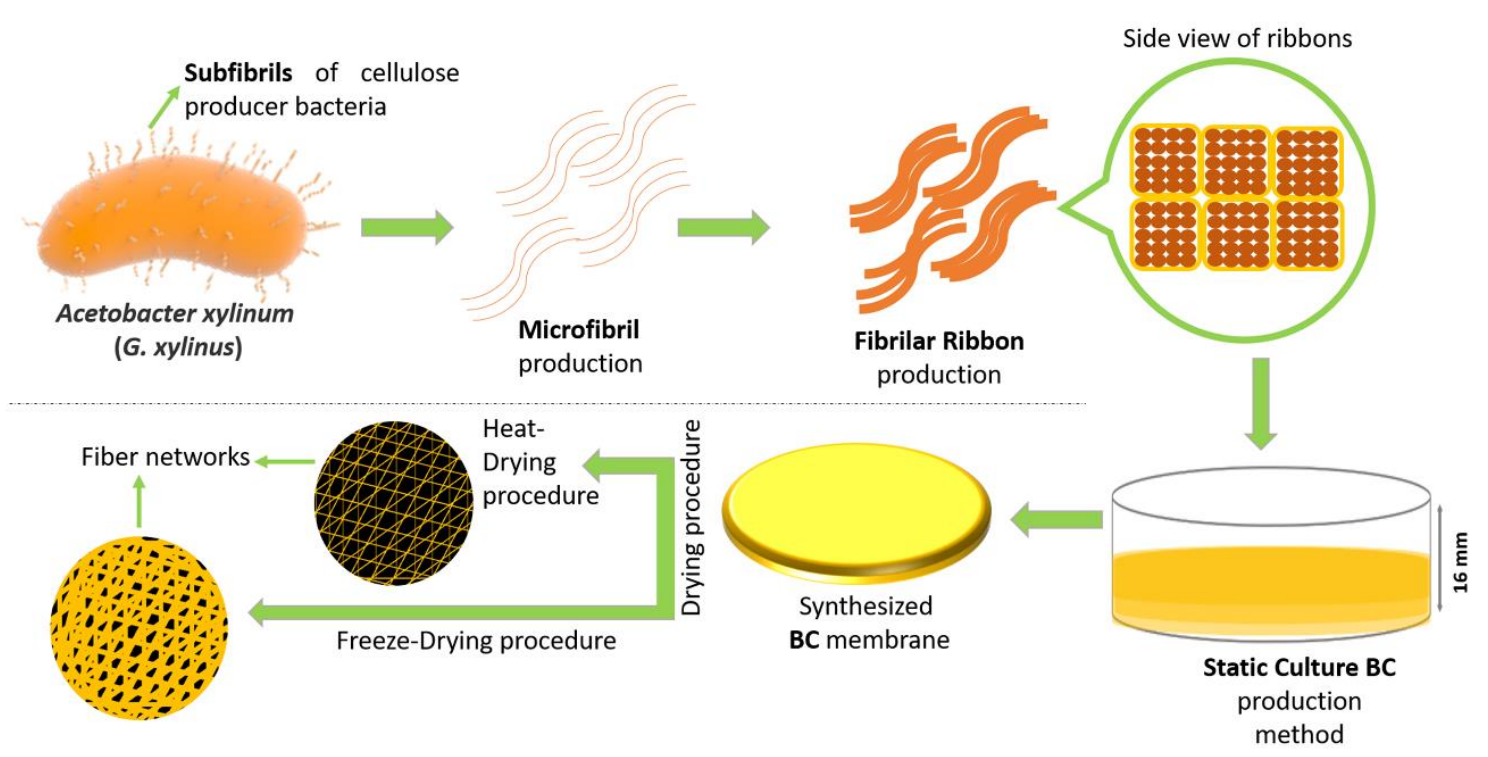

Figure 2: Diagrammatic representation of $B C$ from microfibrils to fibre networks production, step by step in static conditions. Side view depiction of a thick BC gelatinous membrane mat which assumes shape of environment, shown here on a petri dish. The mat contains highly pure network of $B C$ nanofibrils.

Several techniques exist for $\mathrm{BC}$ production that demonstrate different degrees of potential for economical and commercially viability as a BC fabrication method. The selection of the cultivation method stringently determines the cellulose microstructure and thus its mechanical and physical properties. Static culture methods (Figure 2) employ stationary culture in plastic trays or dishes and have shown to produce a thick and gelatinous BC membrane on the surface of the culture medium which compares with most BC produced and tested (Budhiono et al., 1999; Dudman, 1960). The BC pellicle in a static culture is visible at the surface of the liquid about 2 days from the beginning of the process (Schramm and Hestrin, 1954). An alternative approach to BC cultivation is incorporating an agitated culture such as jar fermenters, horizontal fermenters or internal loop airlift reactors (Kouda et al., 1997; Kouda et al., 1996). Agitated culture approaches can produce cellulose in fibrous suspension forms, pellets, spheres or irregular 
masses (Figure 1B) (Chao et al., 2000; Naritomi et al., 1998a; Tsuchida and Yoshinaga, 1997).

Static culture systems have been widely investigated and their applications have seen successful commercial applications such as in food and in electronics (Bernardo et al., 1998; Yamanaka et al., 1989). Nevertheless, agitated culture methods are usually deemed more suitable for large scale production due to their higher potential production rates when considering total area of cultivation required. There are, however, many problems that are encountered with cellulose production in fermenters that utilise continuous aeration and agitation. The sporadic presence of non-cellulose producing mutants $\left(\mathrm{Ce}^{-}\right)$, leads to the decline in biopolymer production in agitated cultures (Jung et al., 2005; Ross et al., 1991). These mutants are a result of the inactivation of the gene coding for cellulose synthesis (Krystynowicz et al., 2002). In static conditions, cellulose-synthesising Gluconacetobacter cells $\left(\mathrm{Cel}^{+}\right)$migrate towards the oxygen-rich medium air interface, where they produce the gelatinous membrane. The membrane limits access to oxygen into the lower depths of the culture and majority of the cells are found in the $\mathrm{Cel}^{+}$form. In agitated systems, the uniform aeration leads to preferential growth of bacterial cells instead of cellulose synthesis, in this case the culture is dominated with Cel mutants (Krystynowicz et al., 2002). Furthermore, it was shown that static cultures of $G$. xylinum actually leads to higher yield levels than with swirled cultures, at a period of 2 days following incubation yield was 1.8 $x$ higher in static cultures than with agitated and after 5 days yield was $2.8 x$ higher in static conditions (Schramm and Hestrin, 1954). Static systems can be less favourable for scale up operations due to the amount of free space required and could limit productivity rate.

Culture conditions can have a marked effect on cellulose production for many different strains of bacteria capable of producing BC (Rangaswamy et al., 2015). Factors such as inoculum density influence the microbial cellulose production, where increasing the concentration of the substance can lead to a reduction in yield, therefore there is an optimum density which needs to be considered. Additionally, there exists an ideal $\mathrm{pH}$ range in which both cell growth and cellulose production is the greatest. In tested conditions from $\mathrm{pH} 3-7$, it was found that a $\mathrm{pH}$ of 6 led to maximum yield compared to the other $\mathrm{pH}$ values (Rangaswamy et al., 2015). Temperature furthermore effects cellulose production where favourable culture temperatures are around $28-30^{\circ} \mathrm{C}$ and when temperatures exceed $40{ }^{\circ} \mathrm{C}$, $\mathrm{BC}$ production was not observed. Carbon is the sole source of $\mathrm{BC}$ production and thus has a significant influence on the yield of BC and its final morphology. Carbon sources such as fructose, glucose, lactose, maltose, mannitol, mannose and sucrose can be utilised to produce BC from different bacteria, maximum yields are usually observed with using sucrose as the carbon source (Eslahi et al., 2020; Wang et al., 2019). Nitrogen is another essential component in cell growth and cellulose production for many bacterial strains, examples of nitrogen sources are: ammonium chloride, ammonium nitrate, ammonium sulphate and peptone. Optimal BC preparation for certain bacteria can result from the use of peptone as the source of nitrogen. On the other hand, cellulose formation from G. xylinum and glucose has been observed to be limited by the oxygen concentration of the culture, where negligible BC was produced with nitrogen and maximal amounts where produced with 100\% oxygen (Schramm and Hestrin, 1954). 


\section{Structure of Bacterial Cellulose}

Similar to that of plant cellulose, BC shares the same molecular formula $\left(\mathrm{C}_{6} \mathrm{H}_{10} \mathrm{O}_{5}\right)_{\mathrm{n}}$. The exopolysaccharide-produced $\mathrm{BC}$ differs from conventional cellulose in its physical and chemical features. The two cellulose types bear the same chemical similarity being B-1,4-glucans, but differ in their degree of polymerisation (Yoshinaga et al., 1997). The degree of polymerisation for BC is considerably lower, having a typical polymerisation range between 2000-6000 compared to 13000-140000 of plant cellulose.

$\mathrm{BC}$ is composed of twisted ribbon-shaped fibrils approximately 50-100 nm in width and 3-8 nm in thickness (Astley et al., 2001; Brown et al., 1976; Yamanaka and Sugiyama, 2000; Zaar, 1977). It has been shown by X-ray diffraction (XRD), that the size of the microfibrils are associated with its crystallite size (Haase et al., 1974). These ultrafine ribbons have a length of 1-9 $\mu \mathrm{m}$ and form a densely arranged structure stabilised by comprehensive inter-and intra-hydrogen bonding (Bielecki et al., 2005; Esa et al., 2014). The average distance between junction points (pore size) of a typical BC membrane has been calculated to be $0.523 \pm$ $0.273 \mu \mathrm{m}$, and the orientation of the segments as the average angle formed between the $\mathrm{x}$-axis and the segments is $85.64 \pm 0.56^{\circ}$ (J Grande et al., 2008).

The macroscopic structure and morphology of BC fibres are strictly dependant on the cultivation techniques used to produce them (Watanabe et al., 1998). In a static culture, the bacterial cells produce cellulose mats at the surface of the nutrient broth where the interface between the liquid and the oxygen rich air exists. In these conditions, G. xylinum cells continuously extrude subfibrils of cellulose from their surface pores which in turn become crystallised into microfibrils, and are forced down deeper through the growth medium (Bielecki et al., 2005). As a result, the cellulose produced in static conditions result in leather-like pellicles which support the population of $G$. xylinum cells. These pellicles consist of overlapping and intertwined cellulose ribbons which form a grid of parallel but disorganised planes (Jonas and Farah, 1998). Comparatively with cellulose produced in agitated cultures, the adjacent strands of the cellulose mats branch and interconnect to a higher degree prevalent in static cultures. In agitated conditions, the increased branching is observable in the form of fibrous strands and irregular granules dispersed thoroughly through the culture broth (Vandamme et al., 1998). Furthermore, the agitated BC interconnect to form a grid-like pattern (Watanabe et al., 1998). The differences in morphology between cellulose produced by agitated and static conditions also contribute to differing levels of crystallinity, crystallite size and the content of cellulose $I_{\alpha}$. The schematic BC microfibril model, physical properties and biomedical application areas are shown in (Figure 3). 


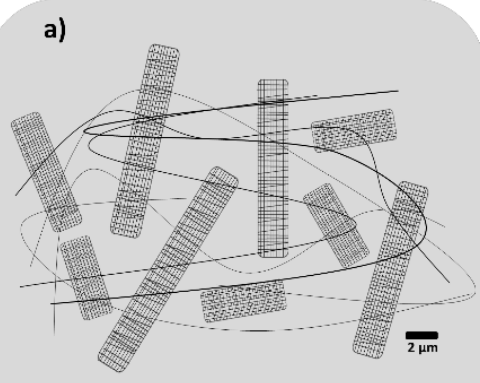

b)

Bacterial Cellulose: Physical Properties

- High porosity

- High mechanical strength

- Biocompatibility

- Permeability

- Biodegradability

- Transparency

- Flexibility

- Hydrophilicity c)

Bacterial Cellulose: Biomedical

Applications

Skin (wound dressing)

$\square$ Cartlidge

- Cornea

$\square$ Bone

U Urethra

Blood vessels

- Contact lenses

- Drug delivery systems

- Bio sensors

Figure 3: a) Schematic diagram of BC microfibrils, showing a unique structure that isn't commonly found in cellulose, b) Physical properties of BC (Hussain et al., 2019), c) Biomedical applications of BC (Gallegos et al., 2016; Portela et al., 2019).

Further differences between agitation produced $\mathrm{BC}$ and statically produced $\mathrm{BC}$ are obvious when viewed using a Scanning Electron Microscope (SEM). Statically produced BC have fibrils with a more extended morphology with fibrils stacked above one another in a crisscross pattern. Conversely, strands of agitation produced BC reveal an entangled and curved physiology (Johnson et al., 1989). Compared to plant cellulose, BC has a unique characteristic in its crystalline structure. Native cellulose consists of cellulose $1 \alpha$ and cellulose $\mid \beta$ crystalline structures, where cellulose $I \beta$ is the major component, approaching approximately $60 \%$ in composition. (VanderHart and Atalla, 1984; Yamamoto and Horii, 1993). Interestingly however, BC contains $60 \%$ cellulose la (Atalla and Vanderhart, 1984).

Another key difference between plant cellulose and BC lies in their morphological structures. In plant cellulose, several cellulose molecular chains assemble to form microfibrils. This assembly subsequently leads to the development of high-order bundles and clusters called fibril lamella and fibre cells (Shoda and Sugano, 2005). Plant cellulose forms a complex structure with impurities such as lignin and hemicellulose. Contrariwise, BC is secreted by $G$. xylinus cells fashioned into a ribbon-like structure composed of microfibril bundles. The fibre diameter of these ribbons are over a hundred times thinner than that of plant cellulose (Guhados et al., 2005). Due to the special ultrafine reticulated structure of BC, there are many unique characteristics that become apparent in their potential and current applications, these are discussed in the next section.

\section{Properties of Bacterial Cellulose}

$\mathrm{BC}$ has a wealth of useful properties that allow it to be used in a wide range of applications, especially in industry and healthcare. The properties are dependent on the structural features as mentioned previously. When the BC pellicle is chemically purified and dried on a flat substrate, a thin and translucent cellulose membrane is established. This membrane holds a plethora of unique properties due to its fine and continuous network of crystalline microfibrils, both in its dried and wet (never-dried) state (Shibazaki et al., 1993).

$B C$ has been discovered to have the highest Young's modulus of any twodimensional organic material, at a staggering stiffness value of $15 \mathrm{GPa}$. The 
extraordinarily high stiffness arises from the strong interfibrillar binding in the network of its ultrafine fibrils and also owning to its high crystallinity (Yamanaka et al., 1989). The effect of sodium hypochlorite ( $\mathrm{NaClO}$ ) and sodium hydroxide $(\mathrm{NaOH})$ on the stiffness of the BC was investigated, the Young's modulus of the $\mathrm{BC}$ sheets further increased to $23 \mathrm{GPa}$ at a $0.5 \%$ concentration of $\mathrm{NaClO}$ and approached $30 \mathrm{GPa}$ at a concentration of $5 \% \mathrm{NaOH}$ (Nishi et al., 1990). Therefore, the mechanical properties of $\mathrm{BC}$ can be further improved with the treatment of alkaline or oxidative solutions, which can be beneficial in many industrial applications where greater stiffness is required. Post-processing of BC allows its mechanical properties to be tailored by exposing it to different chemical treatments, this is especially useful in applications where a highly specific stiffness is desired such as in tissue engineering and cellular wound healing (Chen et al., 2015; Wang et al., 2012).

$\mathrm{BC}$ shows further favourable mechanical properties with high tensile strength, afforded by its highly crystalline structure and fine diameter network of fibres which work together in unison with tensile loads. With a density of $1600 \mathrm{~kg} / \mathrm{m}^{3}, \mathrm{BC}$ microfibrils have an individual Young's modulus of $138 \mathrm{GPa}$ and a tensile strength of more than $2 \mathrm{GPa}$ (Dobre et al., 2010; Nishino et al., 1995). Aramid fibres, a class of heat-resistant and highly strong synthetic fibres used in body armour fabric and ballistic composites, show similar tensile strengths to that of BC, proving how much strength there is in its dense nanofibre network (Young et al., 1992). $\mathrm{BC}$ has shown good potential in material reinforcement in various composites which gives the newly formed composite greater mechanical properties (Gindl and Keckes, 2004; Yano et al., 2005).

Tissue engineering is a rapidly growing field which aims to restore, repair or maintain the function of various vital tissues and organs (Stock and Vacanti, 2001). Biomaterials have been widely used as tissue engineering scaffolds where an ideal material would successfully mimic the extracellular matrix and be able to guide the necessary cells towards effective tissue reformation. Being a natural polymer, BC proves to retain a high level of biocompatibility as shown by studies which show the in vitro and in vivo biocompatibility of BC. Especially, implantations of $\mathrm{BC}$ within rat models have successfully demonstrated biocompatibility with the absence of macroscopic indications of inflammation in response to the implant within the animal (Helenius et al., 2006). Absence of fibrotic encapsulations together with the absence of giant cells point towards good biocompatibility of the material in in vivo conditions. The results here are not surprising given that cellulose-based materials are generally considered biocompatible and thus invoke negligible inflammatory and foreign body responses (Miyamoto et al., 1989).

$\mathrm{BC}$ pellicles demonstrate a high level of chemical purity due to the absence of hemicellulose, lignin, pectin and other biogenic compounds (Song et al., 2009). Removal of hemicelluloses and lignin from cellulosic materials require difficult post processing which adds time and cost and would otherwise pose an economic burden in the manufacturing industry (Frederick et al., 2008). The energy requirement for the purification of $\mathrm{BC}$ is considerably lower than that of other cellulosic materials, allowing for a reduction in processing costs and chemicallyintensive processes which can form hazardous waste products (Gea et al., 2011). Compared to plant and other cellulose sources, BC offers a more economical (in 
terms of purification) and environmental source of cellulose which is unfortunately limited by its production rate.

Due to the nature of its ultrafine fibre network, BC has a very large surface area per unit mass, which gifts it the ability of having a very large water holding capacity. $\mathrm{BC}$ can hold up to 200 times its own dry mass in water, the majority of this liquid is not bound to the polymer and can be easily released via gentle pressing (Lin et al., 2009; Schrecker and Gostomski, 2005; Shezad et al., 2010). The excellent water holding capacity and water release rate of $\mathrm{BC}$ make it suitable as wound dressings. Capillary forces are responsible for holding the water in the cellulose pore structure where water is bound to the cellulose fibrils with hydrogen bonding (Gelin et al., 2007; Ul-Islam et al., 2012). Despite its high water holding ability, the actual $\mathrm{BC}$ fibres are very hydrophobic which permits it to be used in a wide range of civil and industrial applications (Feng et al., 2002; Marins et al., 2011; Yuyang et al., 2006).

$\mathrm{XRD}$ analysis on static-culture produced $\mathrm{BC}$ shows that this material has a crystallinity index of $50 \%$ (Krystynowicz et al., 2002). Cellulose produced by bacteria grown in agitated cultures have shown to acquire a reduced crystallinity compared to those produced in stationary cultures (Czaja et al., 2004). The movement and rotation in agitated cultures cause an external force of disturbance to the fibril crystallisation process, leading to lower crystallinity (Yan et al., 2008). Due to its high crystallinity however, BC has an incredibly low solubility and thus is limited in its processability ( $\mathrm{Hu}$ et al., 2014). It is insoluble in most common solvents that are used in the manufacturing industry which limits its potential applications in these fields. A few solvents have been found to dissolve BC such as lithium chloride with $\mathrm{N}, \mathrm{N}$-dimethylacetamide, sodium hydroxide/urea aqueous solutions and some ionic liquids (Lu and Shen, 2011; Phisalaphong et al., 2008; Shen et al., 2010). These solvents however pose problems in terms of processing costs, health and safety issues due to toxicity, environmental devastation and can also negatively alter the properties of the BC (Aral and Vecchio-Sadus, 2008; Qin et al., 2014). On the other hand, the low solubility of BC can be advantageous in applications where the stability of the material in response to various gas and liquids is crucial, such as in air or water filtration systems (Kosmider and Scott, 2002).

Cellulose, being the most abundant natural homopolymer, shows excellent biodegradability from both plants based and bacterial sources. BC is completely biodegradable in a wide range of environmental conditions, which makes it a promising candidate in environmental protection, biomaterial and tissue engineering applications ( $\mathrm{Li}$ et al., 2009; Wan et al., 2009). Another considerably attractive advantage of $\mathrm{BC}$ is its ability to be physically moulded into any form or size during synthesis (Bäckdahl et al., 2008). This mouldability does not come at the expense of causing any notable alteration to its physical properties. For example, BC grown in a petri dish will take up the shape and volume of the dish and will be formed into a circular gel-like pellicle. A summary of the properties of $\mathrm{BC}$ relating to wound healing can be found in Table 1.

Table 1: Table summarising the key properties of $\mathrm{BC}$ and its relevance to wound healing. 


\begin{tabular}{|c|c|c|c|}
\hline Property & Advantage & $\begin{array}{l}\text { Benefits to Wound } \\
\text { Healing }\end{array}$ & References \\
\hline Biodegradability & $\begin{array}{l}\text { Bandage for } \\
\text { chronic wounds } \\
\text { potentially } \\
\text { doesn't need } \\
\text { removing }\end{array}$ & $\begin{array}{l}\text { Reduction of pain from } \\
\text { bandage removal }\end{array}$ & $\begin{array}{l}\text { (Hu and Catchmark, } \\
\text { 2011; Laçin, 2014) }\end{array}$ \\
\hline $\begin{array}{l}\text { ECM } \\
\text { Resembling } \\
\text { Matrix }\end{array}$ & $\begin{array}{l}\text { Biomimetic } \\
\text { structure } \\
\text { promotes prompt } \\
\text { wound healing }\end{array}$ & $\begin{array}{l}\text { Cells of the wound } \\
\text { response can be guided } \\
\text { to become more efficient }\end{array}$ & $\begin{array}{l}\text { (Svensson et al., } \\
\text { 2005; Wu et al., 2014) }\end{array}$ \\
\hline $\begin{array}{l}\text { Excellent } \\
\text { Biocompatibility }\end{array}$ & $\begin{array}{l}\text { Reduces } \\
\text { complications } \\
\text { with immune } \\
\text { rejection }\end{array}$ & $\begin{array}{l}\text { Risk of fibrotic scarring } \\
\text { is lower }\end{array}$ & $\begin{array}{l}\text { (Helenius et al., 2006; } \\
\text { Torres et al., 2012) }\end{array}$ \\
\hline High Stiffness & Great Durability & $\begin{array}{l}\text { Allows bandage to } \\
\text { withstand some trauma }\end{array}$ & $\begin{array}{l}\text { (Lin et al., 2013; } \\
\text { Nakayama et al., } \\
\text { 2004) }\end{array}$ \\
\hline $\begin{array}{l}\text { High Tensile } \\
\text { Strength }\end{array}$ & $\begin{array}{l}\text { Resistance } \\
\text { against tearing } \\
\text { as a wound } \\
\text { dressing }\end{array}$ & $\begin{array}{l}\text { Provides mechanical } \\
\text { protection against } \\
\text { external trauma }\end{array}$ & $\begin{array}{l}\text { (Naritomi et al., } \\
\text { 1998b; Wan et al., } \\
\text { 2009) }\end{array}$ \\
\hline $\begin{array}{l}\text { High Water } \\
\text { Uptake Ability }\end{array}$ & $\begin{array}{l}\text { Maintains moist } \\
\text { environment and } \\
\text { flow of wound } \\
\text { exudate }\end{array}$ & $\begin{array}{l}\text { Allows for a more } \\
\text { efficient recovery } \\
\text { process and } \\
\text { management of osmotic } \\
\text { environment of cells }\end{array}$ & $\begin{array}{l}\text { (Lin et al., 2009; } \\
\text { Schrecker and } \\
\text { Gostomski, 2005; Ul- } \\
\text { Islam et al., 2012) }\end{array}$ \\
\hline $\begin{array}{l}\text { Large Surface } \\
\text { Area }\end{array}$ & $\begin{array}{l}\text { Increased } \\
\text { interactions with } \\
\text { cells in the } \\
\text { wound response }\end{array}$ & $\begin{array}{l}\text { More efficient cellular } \\
\text { interactions leading to a } \\
\text { healthier recovery }\end{array}$ & $\begin{array}{l}\text { (Iguchi et al., 2000; } \\
\text { Nishi et al., 1990) }\end{array}$ \\
\hline
\end{tabular}

The unique structural and mechanical properties of BC make it suitable for use in a variety of applications such as in food, electronics and medicine (Fontana et al.,

\section{Wound Healing} 1990; Jagannath et al., 2008; Shibazaki et al., 1993). However, out of all the applications, BC has revealed outstanding potential in wound healing and wound care products. The benefit of advanced wound care products and services that address infection and recovery times will function to revolutionise the healthcare industry, its impact would be remarkable for the entirety of the human population. As mentioned previously BC has valuable properties such as its high crystallinity, water holding and absorption capacity, low solubility in solvents and high tensile strength (Figure 3B). These features are all beneficial for skin repair materials.

A good wound repair material has the important characteristic to be able to absorb exudate during and after application and removal. Currently available wound care materials have traditionally showed good absorbance and permeability such as with gauzes which adhere to desiccated wound surfaces, but on removal can cause trauma and damage to the wound site (Boateng et al., 2008). When considering the properties of $\mathrm{BC}$ to current wound care materials, BC shows 
incredible promise in overcoming the downfalls associated with current dressings. Consequently, BC membranes have been used as either wound dressings or skin substitutes. The membrane produced by the bacteria can be directly used from the culture by simply washing the pellicle with water. BC can also be processed further if need be to suit the exact wound healing application.

In the late $20^{\text {th }}$ century, $\mathrm{BC}$ was first used as a temporary skin substitute and biological dressing under the trade name BioFill $\circledast$, now known as Dermafill ${ }^{\mathrm{TM}}$ (Fontana et al., 1990). The product was intended to treat patients suffering from various skin wounds as a result of burns, dermabrasion, cuts and ulcers. Since then, many other BC based products have been commercially available for topological application for wound recovery. Studies show that the use of BC membrane-based dressings establish superiority to conventional materials in reducing wound pain, retaining exudate, accelerating and facilitating reepithelialisation, reducing total healing times, diminishing infection rates and reducing visible scarring (Czaja et al., 2006; Czaja et al., 2007; Fontana et al., 1990). Moreover, due to the translucency of the BC dressing, it is remarkably simple and easy to inspect the wound, without interference or removal of the membrane from the patient.

During the wound healing process, correct moisture levels are required for efficient recovery times. Having a high-water holding ability, BC allows for the wound site to have the ideal moisture conditions. Furthermore, due to the network of its nanofibres, the membrane will prevent infection by creating a physical barrier that will prevent bacteria infiltrating into the wound site preventing the risk of infections (Kaewnopparat et al., 2008; Shezad et al., 2010). The heating of the skin in burn victims causes the breakdown of the semi-permeable membrane associated with the lipoprotein layer in the outermost layer of the skin (stratum corneum) (Jelenko et al., 1968). When the stratum corneum is destroyed, there is a substantial evaporative loss of water which is associated with a large degree of heat loss which can lead to hypermetabolism in burn patients (Lamke et al., 1977). The highwater absorptivity, water retention and vapour transmission features of BC creates an environment where the wound exudate is locked into the dressing whilst also preserving proper wound moisture during healing.

Owing to a multitude of hydroxyl groups, air-dried BC allows the for exceptional water vapour permeability which can be hugely beneficial in wound dressings (Fu et al., 2013). Using air-dried membranes allows for breathable dressings which permit the passage of water vapour through the material. Studies show that an ideal moisture content of a wound environment is one of the most important factors of successful wound healing (Fleck and Simman, 2010). Experimental values of controlled water vapour tests on wound re-epithelialisation and contraction enhancement show that in the case of a dressing with a water vapour transmission rate of $2028 \pm 237.8 \mathrm{~g} / \mathrm{m}^{2}$. $24 \mathrm{~h}$ was found to be in the optimal timescale for healing. (Xu et al., 2016).

A necessity for wound dressings is its competence in maintaining structural integrity between the time period of application and removal, especially when applied near joint areas where movement can cause failure of the dressings. The tensile strength of a BC membrane has been experimentally calculated to be approximately $15 \mathrm{MPa}$ with $32 \%$ elongation at break, the addition of chitosan can increase the Young's modulus (Lin et al., 2013). The tensile strength of BC 
membranes is also dependant of culture conditions and post treatment which can be found to as high as $260 \mathrm{MPa}$ (Kim et al., 2011; Yano et al., 2008). The elongation at break of $32 \%$ for the $\mathrm{BC}$ membrane reveals a high degree of toughness. These properties allow $\mathrm{BC}$ to be extremely suited in a wide range of wound dressings for different wound sites. For example, BC is both mechanically strong and flexible and can thus be produced and be given to patients with knee wounds where their movement will not be restricted and the dressing will not fail.

Cytotoxicity and cell attachment testing on BC membranes have shown that BC maintains high fibroblast viability which is highly desired in a dressing material as cell toxicity would be a major concern for any material that comes in contact with an open wound (Moreira et al., 2009). BC additionally accommodates high level of cell attachment due to its ultrafine network of nanofibers, this feature is especially useful in the progression of wound healing where enhanced cell attachment would play a role in healing acceleration (Diegelmann and Evans, 2004). Furthermore, the ultrafine network presents a high surface area to volume ratio that has potential in cell seeding which can facilitate faster wound regeneration.

The bio-absorbability of $\mathrm{BC}$ allows enhanced restoration of the targeted tissue in a wound environment. Bioabsorbable $\mathrm{BC}$ has been developed and tested in $\mathrm{pH}$ conditions that are commonly found in wound environments (Hu and Catchmark, 2011). It was shown that by incorporating BC with different cellulases, that the degradation rate of the material could be controlled. This permits modified BC to be able to degrade through a function of a predetermined and configurable time.

$\mathrm{BC}$ has shown similarity to the human carotid artery in its stress-strain response curve (Bäckdahl et al., 2006). The resemblance to soft tissue could be due to the comparable architecture of the carotid artery and $\mathrm{BC}$, but this finding also suggests that $\mathrm{BC}$ can be formed to be biomimetic towards tissue and skin. Numerous publications that $\mathrm{BC}$ is also similar to skin, making it suitable as a skin substitute material or a temporary wound treatment dressing (Ciechańska, 2004; Fu et al., 2013; Lee and Park, 2017). An ideal wound dressing system would present similarity to the autograft skin in structure and in functionality (Jones et al., 2002). By mimicking native soft tissue, wound care materials made of $\mathrm{BC}$ could prove to improve patient compliance.

Given its highly nano-porous structure, BC allows for the incorporation of pharmaceuticals and antibiotics into a wound, whilst simultaneously serving as an effective physical barrier against potential infections with its filter-like mesh of microfibrils. Porous fibres for the delivery of active pharmaceutical ingredients is not a new concept, drugs can be easily incorporated into the BC dressing to be released at a controlled or delayed release rate (van de Witte et al., 1993).

When $\mathrm{BC}$ grows in its native conditions, it takes the form of the surrounding environment such as the petri dish. The membrane remains highly mouldable even after extraction from the growth medium. Wounds come in different shapes and sizes and can occur at any part of the body and therefore should not be thought of as a flat surface. The mouldability of BC allows it to be placed on any wound irrespective of where it may be on the patient. BC-based wound dressings can be made to be extremely conformable to the exterior or wounds and allow great levels of comfort that is not experienced by standard gauzes. 
There has been an abundance of work focusing on the improvement of static culture methods for producing BC (Cakar et al., 2014; De Wulf et al., 1996; Vandamme et al., 1998). From an industrial point of view however, the fact remains that these culture systems are inefficient as they are labour intensive and have a long turnaround time. Johnson \& Johnson, a major pharmaceutical company, attempted the commercialisation of BC as early as in the 1980s. The company supported a pioneering series of investigations into the application of BC for different types of wounds, but details of any clinical trials have never been published, and many companies have failed to introduce a commercial wound healing product which incorporates the benefits of BC due to the many difficulties associated with the efficiency of large-scale fermentation (Ring et al., 1986a, b).

Commercial production of BC was again investigated in the 1990s by a number of large Japanese companies and governmental organisations aiming to efficiently mass produce BC (United and Congress, 1993). The $\$ 45$ million effort from these companies resulted in many patents and publications, however there was no indication of commercial success. The 1990's was also the decade when fundamental studies on BC biosynthesis was carried out in Poland. The government-backed initiative lead to successful clinical trials continuing through to the new millennium (Czaja et al., 2006). The study also led to the discovery of an efficient strain of Gluconacetobacter, which is able to produce cellulose in nutrient mediums which were more economical (Krystynowicz, 1997). Therefore, there was a shift in focus to unearthing strains of Gluconacetobacter which would result in higher yields and production rates of BC. The discovery of more efficient bacterial strains allows for advancement into fermentation scale up with promise of commercialisation.

The major obstacle preventing commercialisation is the efficiency of the current production technologies. Manufacturers of BC based artificial skin have been varying concentration of carbon sources, surface/volume ratios of the cultures, and duration of fermentation in the effort to scale production (Czaja et al., 2006). Unlike other bacterial polysaccharides, BC cannot feasibly be synthesised economically in large stirred-tank fermentation systems. Agitated microbial cultures have been shown to have a reduction in cellulose yield and a loss of attractive properties such as crystallinity.

Until very recently, a different approach to $\mathrm{BC}$ manufacturing has been on the rise with numerous publications from both academia and industry. The endeavour to form BC into a secondary fibrous form via highly controlled fibre forming techniques has seen a rise. Fibre forming techniques such as electrospinning have been utilised to create ultrafine fibres with $B C$ that can be used in a wide range of potential applications such as drug delivery, tissue engineering and wound healing (Abeer Muhammad et al., 2014; Mohd Amin et al., 2012; Svensson et al., 2005). The benefit of being able to process BC into fibres are vast. The ability to produce continuous nano- and micro-fibres from BC allows for the fabrication of bandages from small amounts of raw material. Furthermore, this allows for the tailor ability of fibre morphology and also allows for potential industrial scale up of $\mathrm{BC}$ manufacturing which requires less raw or pure BC. 
Electrospinning is an electrohydrodynamic technology in which a polymer solution is fed through a needle that is connected to a high voltage power supply (Luo et al., 2012). The solution becomes charged as it flows through the needle and the electrical stresses overcome the surface tension of the polymer solution (Deitzel et al., 2001). The droplets emerging from the tip of the needle converge into a conical shape (Taylor cone) as a result of the balance between various forces, and a polymer jet is ejected from the apex of this cone (Kim and Reneker, 1999). It is this jet that leads to the production mechanism as the solvent subsequently evaporates and in its stead leaves dried, uniform fibres (Feng, 2002). The technology is summarised by (Figure 4).

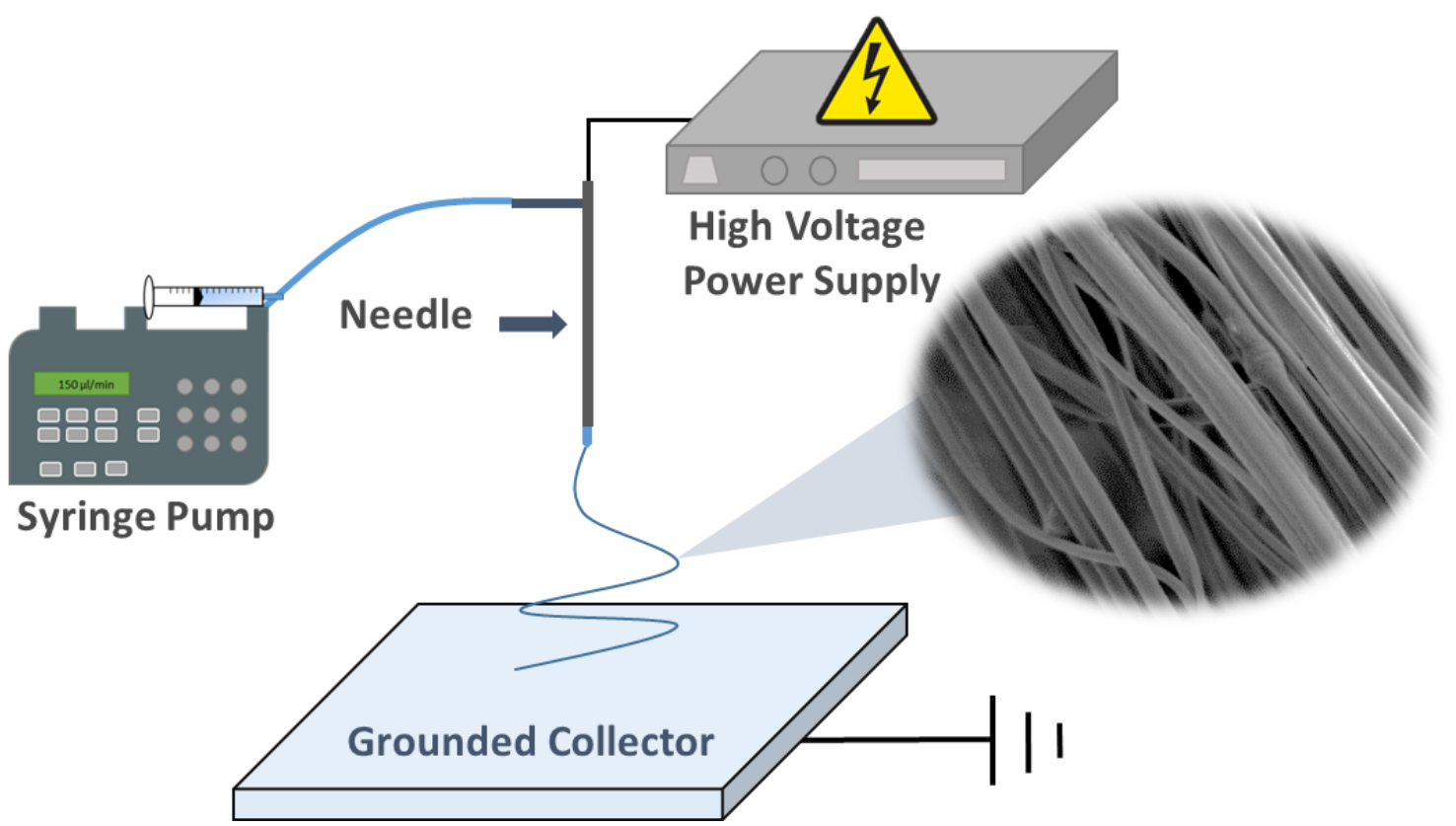

Figure 4: Schematic representation of the electrospinning setup showing a syringe pump where polymer solution is fed through the needle, upon contact with a high voltage electric field, a Taylor cone appears, and fine fibres are formed produced as a result.

Being one of the more established laboratory fibre forming techniques, much attention has gone into forming fibres via this facile technique. BC nano whiskers have been used to improve the mechanical properties of other fibres which are produced by other polymers. The improvement of mechanical properties mainly depends on the extent of BC nano whiskers dispersion in the fibres within the matrix. These whiskers are high aspect ratio (length to diameter ratio) cellulose crystal suspensions, extracted from the cellulose source and reveal a needle like structure under SEM (Bercea and Navard, 2000). They are identified as whiskers due to their elongated shape and their high crystallinity achievement, by creating mixtures of these crystal suspensions with polymer lattices, there is a drastic enhancement of mechanical properties at even a low weight fractions (Favier et al., 1997). BC whiskers can also be obtained by acid hydrolysis of the BC microfibrils, forming highly crystalline rod-like particles (Dufresne, 2000). 
Blends of $\mathrm{BC}$ and Poly(ethylene oxide) (PEO), a water soluble polymer have The solution was able to form fibres such as the PEO would, the BC whiskersreinforced fibres showed a significant increase in Young's modulus, percentage extension at break and maximum stress. Furthermore, ethylene vinyl alcohol (EVOH) fibres were also spun with electrospinning, XRD studies showed that the $\mathrm{BC}$ whiskers had a highly crystalline structure $(73.1 \%$ crystallinity index $)$ compared to untreated BC membranes (Martínez-Sanz et al., 2011). There is an abundance of polymers used in biomedical and tissue engineering that suffer from poor mechanical properties, therefore, electrospinning of $\mathrm{BC}$ has shown to have great potential in composite material reinforcement (Gindl and Keckes, 2004; Pommet et al., 2008; Wan et al., 2009).

More recently, improvements in the portability of electrospinning devices have allowed for point-of-need spinning of fibrous constructs with great potential in wound healing applications (Sofokleous et al., 2013). The ability to directly spray an active patch onto a wounded patient allows for the control of fibre morphology, patch thickness, material choice, easy transport and storage of nanofibrous products and gives complete control over wound coverage and thickness. Polycaprolactone (PCL) was used as a carrier polymer along with 8 differing ratios of $\mathrm{BC}$ to generate BC-PCL composite nanofibres which could be exploited in use as emergency point-of-need wound care using a novel electrohydrodynamic gun (Aydogdu, M. O. et al., 2018). BC was processed into fibres after being suspended in dimethylformamide (DMF) and subjected to ultrasonication to form a gel-like solution that could be mixed with the PCL polymer solution. BC shows only slight solubility in DMF, but the sonication process reduces the particle size of the $\mathrm{BC}$ membrane to improve solubility.

From the electrohydrodynamic gun study on $\mathrm{BC}$, it was found that the increase in $\mathrm{BC}$ content from 5 to $10 \mathrm{wt} \%$ resulted in an increased frequency of beads in the fibres (Aydogdu, Mehmet Onur et al., 2018). However, it was also observed that the bead count could be reduced by increasing the carrier polymer concentration. Other experimental studies show that the main factors which contribute to bead formation in electrospinning are to do with solution properties such as: low molecular weight, low concentration, low viscosity, high surface tension and low charge density (Fong et al., 1999). The solution properties of the BC-PCL solutions where experimentally measured, it was found that the increase of $B C$ content from 5 to $10 \mathrm{wt} \%$ actually increased viscosity and electrical conductivity but only slightly increased the surface tension of the solution. The increased presence of beads in this case may be due to the rise in surface tension seen from the addition of $B C$, other than the other measured solution properties.

An important property of $\mathrm{BC}$ is it's biocompatibility and ability to mediate cellular interactions similarly to that of native tissue in numerous instances (Bäckdahl et al., 2006; Torres et al., 2012). The produced BC-PCL fibres where tested with Saos-2-human osteosarcoma cell line which had osteoblastic characteristics (Rodan et al., 1987). In an MTT assay after 72 hours, all BC-PCL fibrous samples showed cell viability in excess of $75 \%$. It was found that by increasing the PCL concentration, the cell viability increased, possibly due to the increase in fibre diameter favoured by the cells. In the case for 5 and $15 \%$ PCL, cell viability increased with increasing BC content, however due to the cell viability of PCL 
alone being very high, it is difficult to determine whether any increase in cell viability was due to an increase in $\mathrm{BC}$ content. Nonetheless, it can be concluded that a BC-PCL composite system is very capable of retaining an acceptable level of cell viability.

The cellular interaction with the BC-PCL scaffolds were observed by SEM. Cells appeared to cover the scaffold and fill the spaces in the nanofibre matrix. Here were two dominant cell morphologies that could be determined from the micrographs, the cells along the axial length of the fibres depicted an elongated morphology whilst globule-shaped cells where seen at the intersections of the fibres. The presence of the elongated cells indicated that cytoskeletal rearrangement may have taken place which has been previously reported to activate nearby receptors which affects gene expression (Curtis and Wilkinson, 1997). The ability for a material to absorb water is an important factor in a wound dressing, a high swelling ratio permits exudate absorption and the efficient exchange of nutrients and waste (Martin, 1997). All BC-PCL samples showed a high level of water uptake in swelling tests whilst the sample with the highest concentration of $\mathrm{BC}$ and polymer showing the highest swelling percentage.

Nerve tissue engineering is a popular topic in biomedicine due to the limited regeneration capacity of native nerves. A study into the production of nanofibrous scaffolds for enhancing peripheral nervous system neural tissue regeneration and neurite outgrowth was carried out using a BC-PCL polymer mix (Altun et al., 2019). When a gap larger than $3 \mathrm{~cm}$ between peripheral nerves occurs, axon regrowth is extremely difficult, nerve tissue engineering thus provide scaffolds that aid this crucial regeneration (Monaco et al., 2017). Here a concentration of $5 \%(w / w) ~ B C$ was dissolved in a 50:50 solvent ratio of chloroform and DMF, dissolution required ultrasonic agitation of 5 hours over a period of 15 days. The dissolution process was captured optically every 3 days: days 1-3 showed no disintegration of the BC, days 4-6 showed slight disintegration, days 7-9 illustrated decomposition of the BC particles, at days 10-12 the dissolution process continued where whisker-like structures where observed, day 15 showed good dissolution (Figure 5). Mechanical strength is important in nerve tissue engineering as the constructs must be able to withstand the forces and motion of everyday interaction and movement where nerves will stretch and contract. The addition of $\mathrm{BC}$ into the fibrous scaffold doubles the tensile strength from 14.6 MPa to 29.3 MPa. The average diameter of the produces fibres for the PCL scaffolds was $527 \mathrm{~nm}$ and for the BC-PCL scaffolds there was a range of $70-120 \mathrm{~nm}$. 

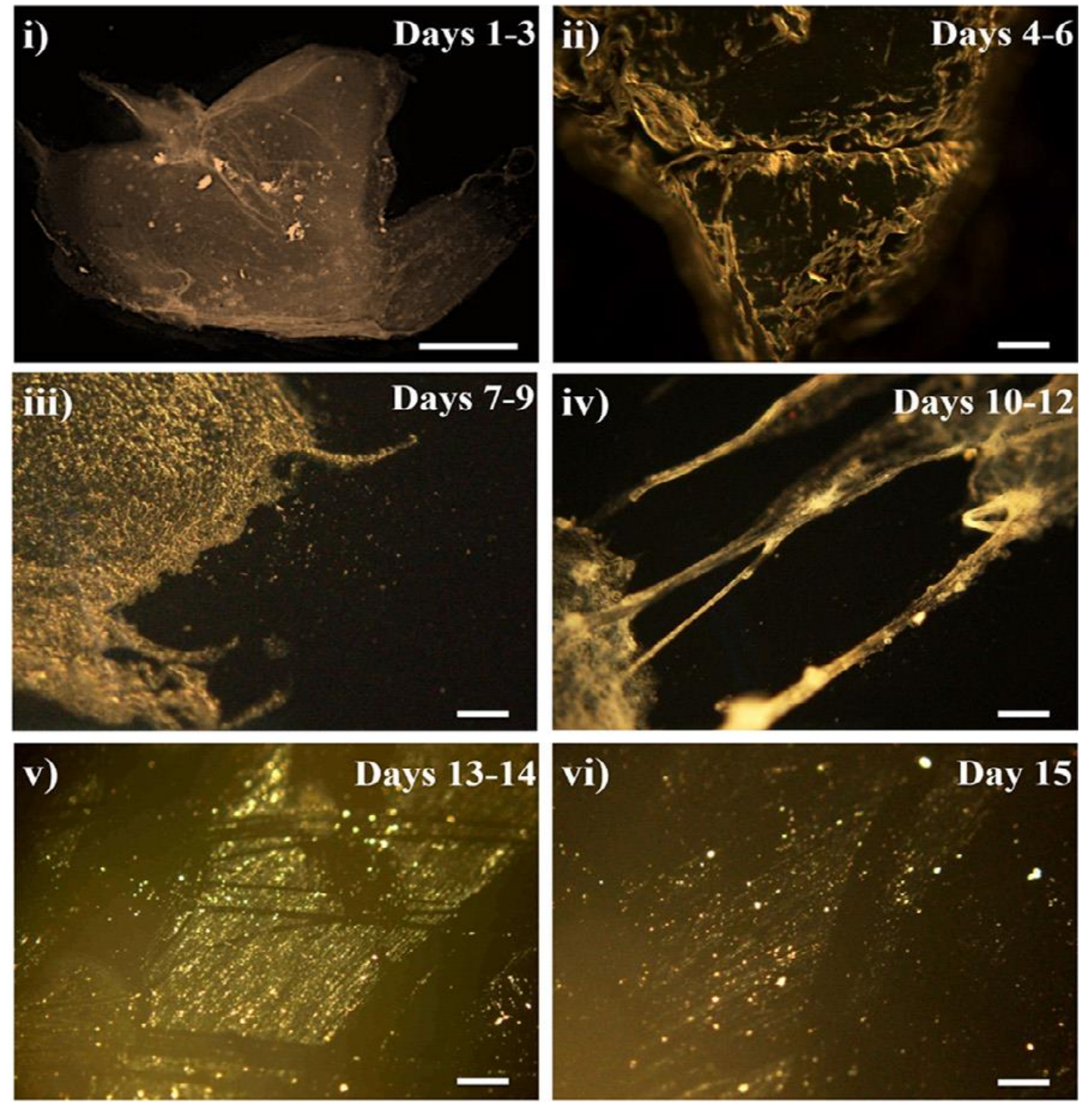

Figure 5: $\mathrm{BC}$ dissolution process is illustrated using optical microscope images:

634 (i) Days 1-3, (ii) Days 4-6, (iii) Days 7-9, (iv) Days 10-12, (v) Days 13-14 and 635 (vi) Day 15. Scale bar $=1 \mathrm{~mm}$ (Altun et al., 2019).

The hybridisation of fibre scaffolds with hydrogels improves mechanical durability and alters its biocompatibility and functionality (Kouhi et al., 2019). A concurrent electrospinning/electrospraying technique was utilised to produce fibrous hydrogel of keratin/ tragacanth gum-conjugated BC hydrogel (Azarniya et al., 2019). The setup was centred around a rotating mechanical mandrel where two separate electrohydrodynamic setups could deposit onto it, on one side was an electrospinning needle and on the other was an electrospraying needle. The into the fibre network without having an effect on its porosity or diameter 645 distribution. The hybrid product would act as a temporary skin substitute, in order 646 to cope with the mechanical durability demands, BC was incorporated into the 647 fibrous mats at different concentrations. In this work a concentration of 1,3 and 5 648 wt\% BC was prepared in a solution with keratin and PEO where acetic acid was 649 used as the solvent. The produced fibrous mats without BC had an average fibre 650 diameter of $243 \pm 57 \mathrm{~nm}$. With the addition of BC, it was noticed that there were 651 fibre breakdowns and a higher number of inter-fibre bonds present which may be 
652 the result of $\mathrm{BC}$ affecting the solvent evaporation rate. The formation of fibre 653 branches when BC was added can be explained by the theory that the surface of 654 a conductive fluid jet can undergo statistic equilibrium undulations via the combined effects of surface tension and electric Maxwell stresses (Yarin et al., 2005). Remarkably, the average fibre diameter was reduced to $150 \pm 43 \mathrm{~nm}$ when $\mathrm{BC}$ was added at $1 \%$ and subsequent higher conditions did not yield much change in the fibre diameter.

Hydrophobicity is an important characteristic to consider for materials in wound healing and in tissue engineering as it can affect biocompatibility of protein adsorption and cellular interaction with the material (Pertile et al., 2010). The keratin-based nanofibers produced without $\mathrm{BC}$ were hydrophobic and had a water contact angle of $126^{\circ}$. The addition of BC saw the hydrophobicity to significantly reduce and at $1 \mathrm{wt} \% \mathrm{BC}$, the water contact angle was $83^{\circ}$. This enhanced hydrophobicity of the fibres and is due to the hydrophobic nature of $\mathrm{BC}$ via its highly porous nonwoven network of nanofibrils. The incorporation of BC into the fibres also shows a significant enhancement in mechanical strength. At only $1 \%$ $\mathrm{BC}$ concentration and compared to keratin-PEO fibres, there is an increase from 7.1 $\mathrm{MPa}$ to $13.3 \mathrm{MPa}$ in the tensile strength,123 MPa to $250 \mathrm{MPa}$ in the elastic modulus and reduction in the elongation at break from about $15 \%$ to $10 \%$. The enhanced mechanical durability of the BC-reinforced fibres is probably afforded by the reorientation of the $\mathrm{BC}$ fibrils and the entanglements between the keratinPEO fibres (Astley et al., 2003). Furthermore, the interfacial cohesion between the $\mathrm{BC}$ and the keratin-PEO fibres in addition to the reduction in fibre diameter from the inclusion of BC can also be responsible for the improved mechanical properties (Wan et al., 2009). The study also carried out in vitro cell studies with the fibres, it was found that keratin-BC fibrous composites had an acceptable level of cytocompatibility as assessed through MTT assays where there was over $90 \%$ cell viability in L929 fibroblast cells (Azarniya et al., 2019).

\subsection{Pressurised Gyration}

Pressurised gyration is a hybrid fibre forming technique which combines solution blow spinning with centrifugal spinning to form low diameter fibres with a rapid production rate and can be used to generate bandage-like fibrous mats (Ahmed et al., 2019; Heseltine et al., 2018; Mahalingam and Edirisinghe, 2013). The setup consists of an aluminium vessel with multiple small apertures on its exterior which is connected to a high-speed motor and a gas inlet. The vessel rotates at high speeds and gas is infused simultaneously into the vessel which drives the polymer solution out through the orifices forming a polymer jet (Ahmed et al., 2018). The polymer jet gives rise to fibre production much like electrospinning as the solvent evaporates. This technique not only allows for very high throughput of production, but also allows you to control final fibre morphology by varying the rotation speed and the magnitude of applied gas pressure (Alenezi et al., 2019). Orientation of fibre bundles to generate mats of wound dressings can be manufactured in this way.

BC fibres blended with poly(methyl methacrylate) (PMMA) at several different ratios have been successfully formed with pressurised gyration to produce biocompatible fibrous scaffolds (Figure 6) (Altun et al., 2018a). 5 and $10 \mathrm{wt} \%$ of $\mathrm{BC}$ solutions were made in a 50:50 wt:wt ratio in DMF and tetrahydrofuran (THF). 
The BC was subjected to ultrasonication for an hour in order to form a gel that could be spun using pressurised gyration. The ratio of BC:PMMA was altered and physical properties were determined along with further tests including SEM imaging, fourier-transform infrared spectroscopy (FT-IR) and cell proliferation studies. Solution viscosity and surface tension was discovered to have increased with elevating BC-PMMA wt ratios, similar with electrospinning, these parameters fundamentally alter fibre formation in pressurised gyration. SEM imaging showed greater particle count on the fibres with higher ratios of BC-PMMA, indicating that these particles were caused by the higher BC content. The FT-IR spectra on the $B C-P M M A$ fibres confirmed presence of $B C$ on the fibres as the profiles were consistent with that of pure $\mathrm{BC}$ and PMMA.

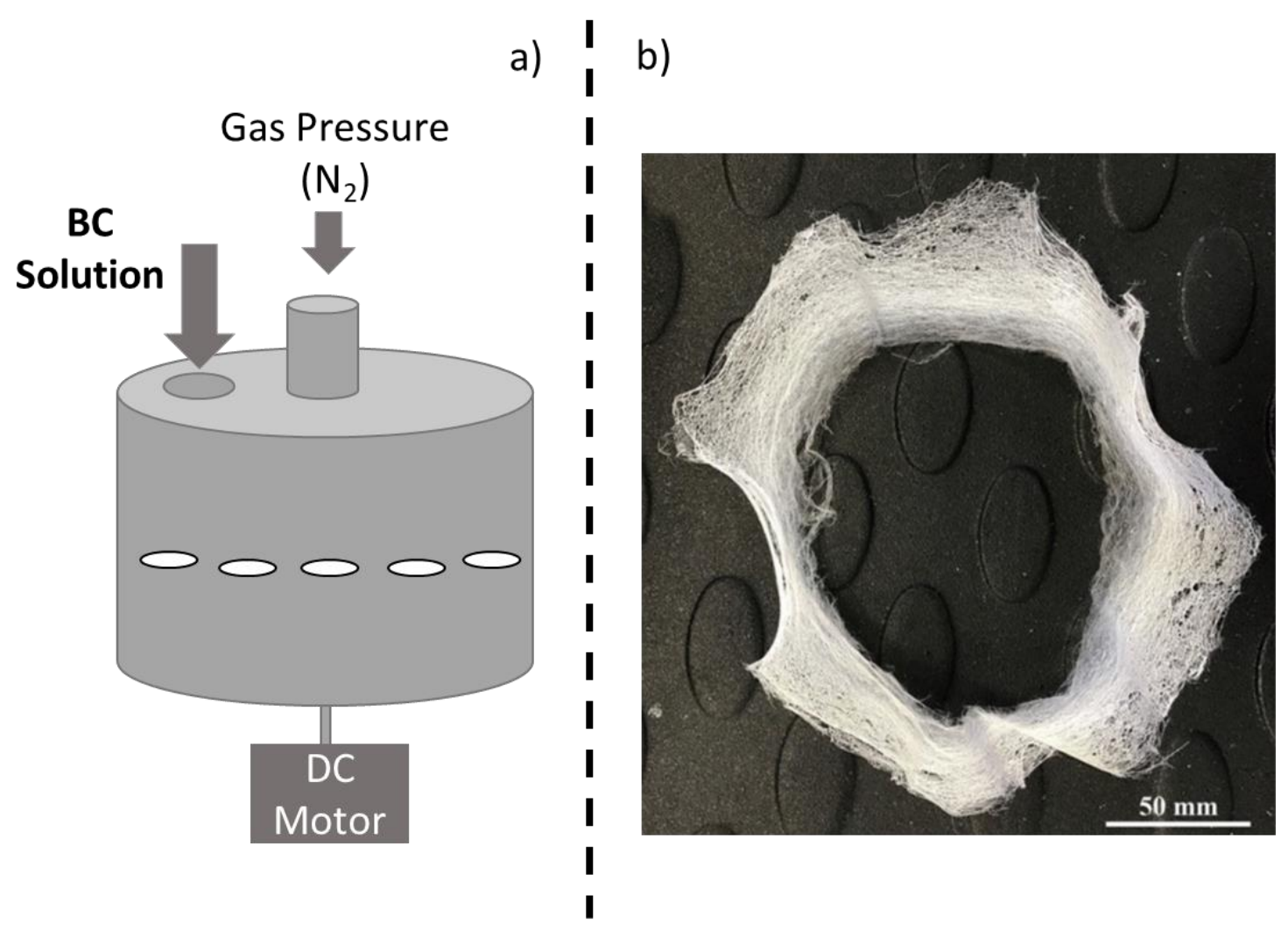

Figure 6: Schematic representation of a) pressurised gyration setup, b) Photograph of the bandage-like fibrous mat produced from the 5:50 (wt ratio) BC:PMMA blend.

Having applications in wound healing the scaffold must be biocompatible, nontoxic and must allow for adequate cell attachment, migration, proliferation and differentiation (Sachlos and Czernuszka, 2003). BC-PMMA scaffolds produced by pressurised gyration where investigated and found to be biocompatible with no indication of toxicity to the tested Saos-2 cell line. Adding BC to the BC-PMMA fibres increased cell viability compared to just solely using PMMA fibres. BCPMMA scaffolds with $5 \mathrm{wt} \% \mathrm{BC}$ were considered appropriate for wounds dressing applications because they retained cell viability of over $85 \%$. The produced scaffold demonstrated cell spreading and proliferation of DAPI stained cells, the scaffolds showed enhanced metabolic activity compared to the control (Figure 7). MTT assays demonstrated that the scaffolds of $5 \mathrm{wt} \%$ had improved metabolic 
activity and proliferation of the seeded cells compared to the $10 \mathrm{wt} \% \mathrm{BC}$.

728 Furthermore, preliminary mechanical tests on the scaffolds revealed that the BC729 PMMA fibres had lower stiffness and higher ductility, the tensile strength of 5:50 730 BC-PMMA was 2.6 times greater than PMMA fibres produced by electrospinning.
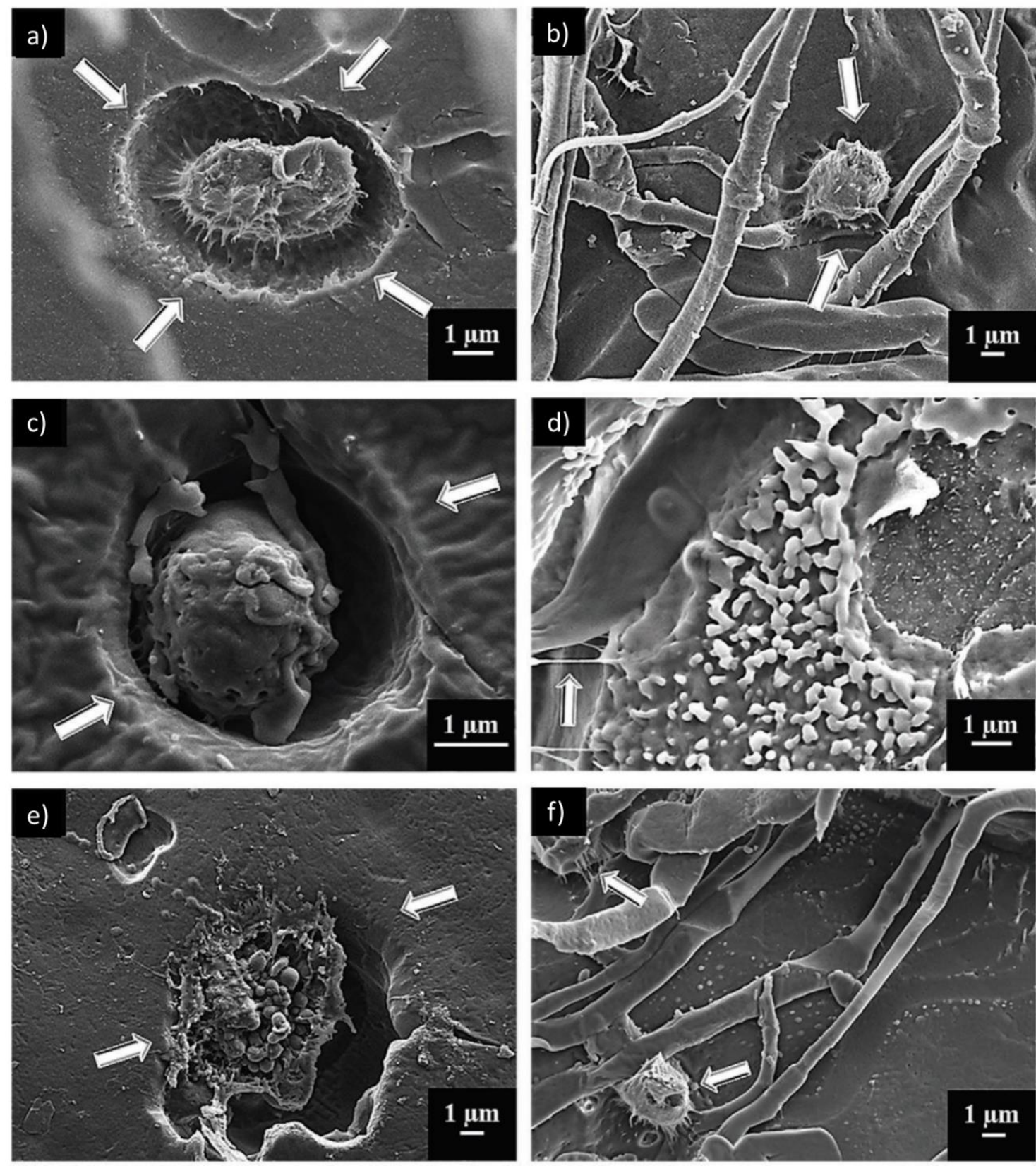

Figure 7: Scanning electron microscopy images of the BC:PMMA scaffold samples 72 hours after incubation with Saos-2 cell line with ratios of: a) 5:30, b) 10:20, c) 5:40, d) 10:30, e) 5:50, and f) 10:40. Arrows indicate embedded cells and their extension (Altun et al., 2018a).

Bandage-like polymeric structures were also produced using pressurised gyration using $\mathrm{BC}$ and PMMA blends with the addition of metallic antimicrobial nanoparticles (Altun et al., 2018b). In this study, BC was incorporated into a polymer solution of PMMA using sonication in a 50:50 solvent mixture of DMF and THF. Additionally, two types of nanoparticle mixtures were also added; one using $\mathrm{Cu}-\mathrm{Ag}-\mathrm{Zn} / \mathrm{CuO}$ and the other including $\mathrm{Cu}-\mathrm{Ag}$-Tungsten carbide. The study 

showed that BC-PMMA bandage-like fibres could be produced at a high yield with pressurised gyration and that these fibres can have antimicrobial nanoparticles incorporated for improved mechanical properties, higher water uptake ability and lower cell cytotoxicity.

An investigation into the maximal loading of $B C$ in binary and ternary blends of fibres was carried out with an emphasis on production yield and mechanical properties by (Aydogdu et al., 2019). Poly(lactic acid) (PLA) and PCL fibres were created with and without blends of BC, eventually an optimised composite of PCLPLA-BC was also created. For pure PLA fibres, there was a 92\% yield, and the addition of $B C$ into the polymer matrix caused a deterioration of yield down to $54 \%$ at only $10 \mathrm{wt} \% \mathrm{BC}$. It was observed that a huge fall in yield occurs as a result of higher BC loadings, as attested to by many other articles (Altun et al., 2018b; Aydogdu et al., 2019; Azarniya et al., 2019). Pure PCL fibres had a yield of $87 \%$ and saw a drop to $61 \%$ yield when loaded by $10 \mathrm{wt} \%$ BC. PLA and PCL composites were also produced and tested to compare the ternary behaviour of the different polymer systems. The 90:10 PLA-PCL blend had a very high yield of $97 \%$, which also showed that these polymers worked very well as composites.

A BC concentration of $30 \mathrm{wt} \%$ was deemed the highest concentration whilst maintaining an acceptable level of yield (>30\%) and mechanical integrity. The BC in the polymeric solution also caused an increased frequency of beads within the fibres. As expected, the addition of BC to the solutions lead to an increase in viscosity and thus caused thicker fibres to be formed in the presence of $\mathrm{BC}$.

With an increasing concentration of BC in PLA binary systems, the ultimate tensile increases with each $10 \%$ increment. PLA alone has a tensile strength of $2.3 \mathrm{MPa}$, at $10 \mathrm{wt} \% \mathrm{BC}$ concentration the tensile strength is $3.8 \mathrm{MPa}, 20 \mathrm{wt} \%$ it's at $5.4 \mathrm{MPa}$ and at $30 \mathrm{wt} \%$ it is $6.5 \mathrm{MPa}$. At $40 \mathrm{wt} \% \mathrm{BC}$ concentration, the PLA fibres lose mechanical integrity and the tensile strength drops to $2.3 \mathrm{MPa}$ as the $\mathrm{BC}$ content increases. This drop in tensile strength corresponds with the reduced fibre count and yield with high $B C$ levels which impairs the integrity of the bandages. The results for the stiffness of the PLA-BC binary system follows the same trend. The stiffness of PLA increases from $10 \mathrm{wt} \%$ to $30 \mathrm{wt} \%$ of added BC, it then falls sharply at $40 \mathrm{wt} \%$ and continues to drop.

The mechanical behaviour of the PLA-BC binary polymer system follows a similar trend with the PLA-BC polymeric fibres. With $100 \% \mathrm{PCL}$, the tensile strength is around $2.3 \mathrm{MPa}$, the addition of $10 \mathrm{wt} \% \mathrm{BC}$ creates an increase in tensile strength to about 2.7 MPa. PCL proves to be a superior carrier of BC compared to PLA when comparing tensile strength as $50 \mathrm{wt} \% \mathrm{BC}$ shows the highest value at around 6.7 MPa. At a $100 \%$ concentration of PCL, the Young's modulus is around 23 $\mathrm{MPa}$, the addition of $\mathrm{BC}$ at $10 \mathrm{wt} \%$ causes an increase of stiffness to about 27 $\mathrm{MPa}$ and at a 40 wt \% concentration of $\mathrm{BC}$ the stiffness drops to $\sim 12 \mathrm{MPa}$.

This study then focused on the production of PCL and PLA fibres with BC loading, ultimately to design an optimised ternary polymeric system with a mixture of PCL, PLA and BC. The optimised ternary sample consisted of $70 \mathrm{wt} \%$ mixture of PLA and PCL and $30 \mathrm{wt} \% \mathrm{BC}$, it had a higher tensile strength than both PCL and PLA at around $9 \mathrm{MPa}$ and had a high stiffness of around $19.6 \mathrm{MPa}$. It showed that BC can be used in binary and ternary polymeric systems to produce fibres that can benefit from the mechanical characteristics of multiple polymers. 
792 Due to the large number of inter- and intra- molecular hydrogen bonds, BC is very difficult to process into solution, which is a necessity in order to generate fibres using major methods such as electrospinning. BC is an especially insoluble material and does not dissolve in common organic solvents such as acetone, chloroform and DCM. Experimental results show that BC has partial solubility in $8.5 \mathrm{wt} \%$ aqueous sodium hydroxide $(\mathrm{NaOH})$ solution (Łaskiewicz, 1998). Even then, temperatures of $-5^{\circ} \mathrm{C}$ are required, only about $20 \mathrm{wt} \%$ of the cellulose is dissolved and the degree of polymerisation of the $\mathrm{BC}$ source must be low too. The solubility of $\mathrm{BC}$ in $\mathrm{NaOH}$ solution can however be further increased when $1 \mathrm{wt} \%$ urea is added. Even then, BC is not completely soluble in these conditions, and the use of such acids and chemicals can lead to toxic production environments and hazardous industrial waste.

High molecular weight BC was discovered to be soluble in a binary solvent system of lithium chloride/N,N-dimethylacetamide (LiCl/DMAc) (Shen et al., 2010). It was also found that the type of BC membrane and how it was formed had a large effect on its solubility with these solvents. BC samples with large grains in their microstructure were more prone to form large gels during the swelling stage of dissolution which hindered additional diffusion of the solvent into the fibres. The samples that showed good solubility were those that were in powdered form, having much higher surface area to volume ratio. There are several activation procedures that can improve the initial solubility of cellulose and BC including treatment with liquid ammonia, freeze drying and swelling in water followed by solvent exchange in dimethylacetamide (Morgenstern and Berger, 1993; Rohrling et al., 2002). These activation steps are thought to induce inter- and intracrystallite swelling, increase accessibility and break of hydrogen bonds. Temperature was also found to have a marked effect on dissolution where temperatures below $45^{\circ} \mathrm{C}$ caused difficulty in dissolution and activation temperatures over $60^{\circ} \mathrm{C}$ showed greater dissolution.

BC with a high degree of polymerisation (6500) was dissolved in 1-n-butyl-3methylimidazolium where temperatures of $80^{\circ} \mathrm{C}$ and 12 hours of mechanical stirring were required (Schlufter et al., 2006). The dissolution by 1-n-butyl-3methylimidazolium was found not to significantly degrade the polymer chains. The ionic liquid, 1-allyl-3-methyl-imidazolium chloride was also used to dissolve BC but a transition from cellulose I to the cellulose II allomorph was observed with the resulting electrospun fibres (Chen et al., 2010).

Although solubility of $\mathrm{BC}$ has been observed with some ionic liquids, the case remains that these solutions would pose an obstacle in the mass production of $B C$ fibres and other derivative wound care materials. Firstly, the acute toxicity of these liquids is a great concern at both the factory level and through run-off. For example, the toxicity caused by 1-butyl-3-methylimidazolium chloride was investigated in zebrafish and it was found to cause oxidative damage as well as DNA damage (Zhang et al., 2017). Furthermore, the economics of such solvent systems, binary and otherwise, increase the costs to the end consumer with higher processing expenditures and prolonged manufacturing times. High temperature 
processing of $\mathrm{BC}$ increases energy input during manufacturing which is both environmentally and economically detrimental.

\section{Future Developments and Conclusions}

The secondary processing of $\mathrm{BC}$ has proven to be difficult. Due to its nature, large scale production of $\mathrm{BC}$ in wound care materials is not feasible. Therefore, by reprocessing the $\mathrm{BC}$ into secondary fibres and blends, there can be a more commercially feasible methods of mass-producing for the healthcare market. The answer may lie in fibre forming techniques such as electrospinning and pressurised gyration, these methods allow for the tailoring of the fibre structure to best suit for wound healing applications.

However, the solubility of $\mathrm{BC}$ has played a major obstacle in forming spinnable solutions. Work needs to be done to discover solvents that can dissolve the BC membrane in a non-toxic and economical manner, as well as to not remove the fundamental properties of high utilisation value. Spinnable solutions can then be processed into fibres, added to blends containing other natural polymers which can have antibacterial and pro-wound healing effects.

An alternative approach into forming $\mathrm{BC}$ solutions can be to use mechanical force, whereby the BC membrane is broken into smaller particles or fibrils which may improve its solubility in several solvents. Such an approach has been used to spin BC-PMMA scaffolds as discussed previously where high frequency ultrasound has been used to form a gel-like spinnable solution within a carrier polymer. As discussed earlier, the benefit of using ultrasonication is that the crystal structure of the BC is not adversely affected and thus the beneficial wound-healing properties of the material can remain. Moreover, other mechanical methods of reducing $B C$ size can be investigated, such as grinding or blending the $B C$ into particles. The efficacy of such particles in wound healing needs to be also determined.

Blends of $\mathrm{BC}$ within different polymers, both synthetic and natural could prove to be a beneficial commodity in wound care. Composite materials with desired properties such as biocompatibility, biodegradability and anti-bacterial properties can be used to develop wound dressings that overcome the limitations of the production limitation of $\mathrm{BC}$. There are many polymers systems yet to be trialled, even with the difficulty of processing $\mathrm{BC}$, it can still be used to enhance the mechanical and biological properties for effective wound healing.

The remarkable properties of BC were only discovered in the mid-1980s, where before the applications of the it was only really limited to food production of natade-coco. Since then, there has been a steep incline in the number of research articles and patents relating to $\mathrm{BC}$ and various methods for extraction and processing.

A considerable challenge to overcome in $\mathrm{BC}$ technology is the unearthing of a suitable carbon source that is cheap and that does not compete with the production of food. Nevertheless, forming BC membranes into secondary fibres could maximise the use of the material in wound care applications and reduce the volume required to have its clinical effects. There are still many hurdles remaining for the wide use of $B C$ in healthcare settings, but with the abundance of research 
and patents, we could be on the verge of incorporating this very significant and valuable material in crucial advanced technology applications worldwide.

\section{Acknowledgements}

The authors would like to thank University College London for supporting the doctoral research of Jubair Ahmed and for hosting a period of visiting research by Merve Gultekinoglu at the Edirisinghe Lab in UCL.

\section{Conflict of Interest}

The authors declare no conflict of interest.

\section{References}

Abeer Muhammad, M., Mohd Amin Mohd Cairul, I., Martin, C., 2014. A review of bacterial cellulose-based drug delivery systems: their biochemistry, current approaches and future prospects. Journal of Pharmacy and Pharmacology 66(8), 1047-1061.

Ahmed, J., Altun, E., Aydogdu, M.O., Gunduz, O., Kerai, L., Ren, G., Edirisinghe, M., 2019. Antifungal bandages containing cinnamon extract. International Wound Journal 16(3), 730-736.

Ahmed, J., Matharu, R.K., Shams, T., Illangakoon, U.E., Edirisinghe, M., 2018. A Comparison of Electric-Field-Driven and Pressure-Driven Fiber Generation Methods for Drug Delivery. Macromolecular Materials and Engineering, 1700577.

Alenezi, H., Cam, M.E., Edirisinghe, M., 2019. Experimental and theoretical investigation of the fluid behavior during polymeric fiber formation with and without pressure. Applied Physics Reviews 6(4), 041401.

Altun, E., Aydogdu Mehmet, O., Koc, F., Crabbe-Mann, M., Brako, F., Kaur-Matharu, R., Ozen, G., Kuruca Serap, E., Edirisinghe, U., Gunduz, O., Edirisinghe, M., 2018. Novel Making of Bacterial Cellulose Blended Polymeric Fiber Bandages. Macromolecular Materials and Engineering 303(3), 1700607.

Altun, E., Aydogdu, M.O., Crabbe-Mann, M., Ahmed, J., Brako, F., Karademir, B., Aksu, B., Sennaroglu, M., Eroglu, M.S., Ren, G., Gunduz, O., Edirisinghe, M., 2018. Co-Culture of Keratinocyte-Staphylococcus aureus on $\mathrm{Cu}-\mathrm{Ag}-\mathrm{Zn} / \mathrm{CuO}$ and $\mathrm{Cu}-\mathrm{Ag}-\mathrm{W}$ Nanoparticle Loaded Bacterial Cellulose:PMMA Bandages. Macromolecular Materials and Engineering, 1800537.

Altun, E., Aydogdu, M.O., Togay, S.O., Sengil, A.Z., Ekren, N., Haskoylu, M.E., Oner, E.T., Altuncu, N.A., Ozturk, G., Crabbe-Mann, M., Ahmed, J., Gunduz, O., Edirisinghe, M., 2019. Bioinspired Scaffold Induced Regeneration of Neural Tissue. European Polymer Journal 114(2019), 98-108. Aral, H., Vecchio-Sadus, A., 2008. Toxicity of lithium to humans and the environment-A literature review. Ecotoxicology and Environmental Safety 70(3), 349-356.

Astley, O.M., Chanliaud, E., Donald, A.M., Gidley, M.J., 2001. Structure of Acetobacter cellulose composites in the hydrated state. International Journal of Biological Macromolecules 29(3), 193202.

Astley, O.M., Chanliaud, E., Donald, A.M., Gidley, M.J., 2003. Tensile deformation of bacterial cellulose composites. International Journal of Biological Macromolecules 32(1), 28-35.

Atalla, R.H., Vanderhart, D.L., 1984. Native cellulose: a composite of two distinct crystalline forms. Science 223(4633), 283-285.

Aydogdu, M.O., Altun, E., Crabbe-Mann, M., Brako, F., Koc, F., Ozen, G., Kuruca, S.E., Edirisinghe, U., Luo, C.J., 2018. Cellular interactions with bacterial cellulose: Polycaprolactone nanofibrous scaffolds produced by a portable electrohydrodynamic gun for point-of-need wound dressing. International Wound Journal 15(5), 789-797.

Aydogdu, M.O., Altun, E., Crabbe-Mann, M., Brako, F., Koc, F., Ozen, G., Kuruca, S.E., Edirisinghe, U., Luo, C.J., Gunduz, O., Edirisinghe, M., 2018. Cellular interactions with bacterial cellulose: 
929 Polycaprolactone nanofibrous scaffolds produced by a portable electrohydrodynamic gun for 930 point-of-need wound dressing. International Wound Journal 15(5), 789-797.

931 Aydogdu, O.M., Altun, E., Ahmed, J., Gunduz, O., Edirisinghe, M., 2019. Fiber Forming Capability

932 of Binary and Ternary Compositions in the Polymer System: Bacterial Cellulose933 Polycaprolactone-Polylactic Acid. Polymers 11(7), 1148.

934 Azarniya, A., Tamjid, E., Eslahi, N., Simchi, A., 2019. Modification of bacterial cellulose/keratin 935 nanofibrous mats by a tragacanth gum-conjugated hydrogel for wound healing. International 936 Journal of Biological Macromolecules 134, 280-289.

937 Bäckdahl, H., Esguerra, M., Delbro, D., Risberg, B., Gatenholm, P., 2008. Engineering 938 microporosity in bacterial cellulose scaffolds. Journal of Tissue Engineering and Regenerative 939 Medicine 2(6), 320-330.

940 Bäckdahl, H., Helenius, G., Bodin, A., Nannmark, U., Johansson, B.R., Risberg, B., Gatenholm, P., 941 2006. Mechanical properties of bacterial cellulose and interactions with smooth muscle cells. 942 Biomaterials 27(9), 2141-2149.

943 Bercea, M., Navard, P., 2000. Shear Dynamics of Aqueous Suspensions of Cellulose Whiskers.

944

945

946

947

948 
979 Czaja, W.K., Young, D.J., Kawecki, M., Brown, R.M., Jr., 2007. The future prospects of microbial 980 cellulose in biomedical applications. Biomacromolecules 8(1), 1-12.

981 De Wulf, P., Joris, K., Vandamme, E.J., 1996. Improved cellulose formation by an Acetobacter 982 xylinum mutant limited in (keto)gluconate synthesis. Journal of Chemical Technology \& 983 Biotechnology 67(4), 376-380.

984 Deitzel, J.M., Kleinmeyer, J., Harris, D., Beck Tan, N.C., 2001. The effect of processing variables on 985 the morphology of electrospun nanofibers and textiles. Polymer 42(1), 261-272.

986 Diegelmann, R.F., Evans, M.C., 2004. Wound healing: an overview of acute, fibrotic and delayed healing. Frontiers in Bioscience : A Journal and Virtual Library 9, 283-289.

Dobre, L., Stoica, A., M, S., Jinga, S., Jipa, I., Dobre, T., 2010. Characterization of composite materials based on biocellulose membranes impregnated with silver particles as antimicrobial agent. UPB Scientific Bulletin, Series B: Chemistry and Materials Science 72(4).

Dudman, W.F., 1960. Cellulose production by Acetobacter strains in submerged culture. J Gen Microbiol 22, 25-39.

Dufresne, A., 2000. Dynamic mechanical analysis of the interphase in bacterial polyester/cellulose whiskers natural composites. Composite Interfaces 7(1), 53-67.

Esa, F., Tasirin, S.M., Rahman, N.A., 2014. Overview of bacterial cellulose production and application. Agriculture and Agricultural Science Procedia 2(Supplement C), 113-119.

Eslahi, N., Mahmoodi, A., Mahmoudi, N., Zandi, N., Simchi, A., 2020. Processing and properties of nanofibrous bacterial cellulose-containing polymer composites: A review of recent advances for biomedical applications. Polymer Reviews 60(1), 144-170.

Favier, V., Cavaille, J.Y., Canova, G.R., Shrivastava, S.C., 1997. Mechanical percolation in cellulose whisker nanocomposites. Polymer Engineering \& Science 37(10), 1732-1739.

Feng, J.J., 2002. The stretching of an electrified non-Newtonian jet: A model for electrospinning. Physics of Fluids 14(11), 3912-3926.

Feng, L., Li, S., Li, Y., Li, H., Zhang, L., Zhai, J., Song, Y., Liu, B., Jiang, L., Zhu, D., 2002. Superhydrophobic surfaces: from natural to artificial. Advanced Materials 14(24), 1857-1860.

Fleck, C.A., Simman, R., 2010. Modern collagen wound dressings: function and purpose. The journal of the American College of Certified Wound Specialists 2(3), 50-54.

Fong, H., Chun, I., Reneker, D.H., 1999. Beaded nanofibers formed during electrospinning. Polymer 40(16), 4585-4592.

Fontana, J.D., De Souza, A.M., Fontana, C.K., Torriani, I.L., Moreschi, J.C., Gallotti, B.J., De Souza, S.J., Narcisco, G.P., Bichara, J.A., Farah, L.F.X., 1990. Acetobacter cellulose pellicle as a temporary skin substitute. Applied Biochemistry and Biotechnology 24(1), 253-264.

Frederick, W.J., Lien, S.J., Courchene, C.E., DeMartini, N.A., Ragauskas, A.J., lisa, K., 2008. Coproduction of ethanol and cellulose fiber from Southern Pine: A technical and economic assessment. Biomass and Bioenergy 32(12), 1293-1302.

Fu, L., Zhang, J., Yang, G., 2013. Present status and applications of bacterial cellulose-based materials for skin tissue repair. Carbohydrate Polymers 92(2), 1432-1442.

Gallegos, A.M.A., Carrera, S.H., Parra, R., Keshavarz, T., Iqbal, H.M.J.B., 2016. Bacterial cellulose: A sustainable source to develop value-added products-A review. BioResources 11(2), 5641-5655. Gea, S., Reynolds, C.T., Roohpour, N., Wirjosentono, B., Soykeabkaew, N., Bilotti, E., Peijs, T., 2011. Investigation into the structural, morphological, mechanical and thermal behaviour of bacterial cellulose after a two-step purification process. Bioresource Technology 102(19), 91059110.

Gelin, K., Bodin, A., Gatenholm, P., Mihranyan, A., Edwards, K., Strømme, M., 2007. Characterization of water in bacterial cellulose using dielectric spectroscopy and electron microscopy. Polymer 48(26), 7623-7631.

Gindl, W., Keckes, J., 2004. Tensile properties of cellulose acetate butyrate composites reinforced with bacterial cellulose. Composites Science and Technology 64(15), 2407-2413. 
Gould, L., Abadir, P., Brem, H., Carter, M., Conner-Kerr, T., Davidson, J., DiPietro, L., Falanga, V., Fife, C., Gardner, S., Grice, E., Harmon, J., Hazzard, W.R., High, K.P., Houghton, P., Jacobson, N., Kirsner, R.S., Kovacs, E.J., Margolis, D., McFarland Horne, F., Reed, M.J., Sullivan, D.H., Thom, S., Tomic-Canic, M., Walston, J., Whitney, J.A., Williams, J., Zieman, S., Schmader, K., 2015. Chronic wound repair and healing in older adults: current status and future research. J Am Geriatr Soc 63(3), 427-438.

Guhados, G., Wan, W., Hutter, J.L., 2005. Measurement of the elastic modulus of single bacterial cellulose fibers using atomic force microscopy. Langmuir 21(14), 6642-6646.

Haase, J., Hosemann, R., Renwanz, B., 1974. X-ray wide and small angle X-ray examinations on cellulose. Colloid and Polymer Science 252(9), 712-717.

Helenius, G., Backdahl, H., Bodin, A., Nannmark, U., Gatenholm, P., Risberg, B., 2006. In vivo biocompatibility of bacterial cellulose. Journal of Biomedical Materials Research. Part A 76(2), 431-438.

Heseltine, P.L., Ahmed, J., Edirisinghe, M., 2018. Developments in pressurized gyration for the mass production of polymeric fibers. Macromolecular Materials and Engineering 1800218.

Hestrin, S., Schramm, M., 1954. Synthesis of cellulose by Acetobacter xylinum. 2. Preparation of freeze-dried cells capable of polymerizing glucose to cellulose. Biochemical Journal 58(2), 345352.

Hibbert, H., 1930. Action of bacteria and enzymes on carbohydrates and their bearing on plant synthesis. Science 71(1842), 419.

Hu, W., Chen, S., Yang, J., Li, Z., Wang, H., 2014. Functionalized bacterial cellulose derivatives and nanocomposites. Carbohydrate Polymers 101(Supplement C), 1043-1060.

Hu, Y., Catchmark, J.M., 2011. In vitro biodegradability and mechanical properties of bioabsorbable bacterial cellulose incorporating cellulases. Acta Biomaterilia 7(7), 2835-2845.

Hussain, Z., Sajjad, W., Khan, T., Wahid, F.J.C., 2019. Production of bacterial cellulose from industrial wastes: a review. Cellulose 26(5), 2895-2911.

Iguchi, M., Yamanaka, S., Budhiono, A., 2000. Bacterial cellulose-a masterpiece of nature's arts. Journal of Materials Science 35(2), 261-270.

J Grande, C., Torres, F., Gómez, C., Troncoso Heros, O., Canet-Ferrer, J., Martinez-Pastor, J., 2008. Morphological characterisation of bacterial cellulose-starch nanocomposites. Polymers and Polymer Composites 16(4), 181-185.

Jagannath, A., Kalaiselvan, A., Manjunatha, S.S., Raju, P.S., Bawa, A.S., 2008. The effect of pH, sucrose and ammonium sulphate concentrations on the production of bacterial cellulose (Natade-coco) by Acetobacter xylinum. World Journal of Microbiology and Biotechnology 24(11), 2593. Jelenko, C.r., Smulyan, W.I., Wheeler, M.L., 1968. Studies in burns: the role of lipids in the transmissivity of membranes. Annals of Surgery 167(4), 521-532.

Johnson, D.C., Neogi, A.N., LeBlanc, H.A., 1989. Bacterial cellulose as surface treatment for fibrous web. CP Kelco US Inc Weyerhaeuser Co.

Jonas, R., Farah, L.F., 1998. Production and application of microbial cellulose. Polymer Degradation and Stability 59(1), 101-106.

Jones, I., Currie, L., Martin, R., 2002. A guide to biological skin substitutes. British Journal of Plastic Surgery 55(3), 185-193.

Jung, J.Y., Park, J.K., Chang, H.N., 2005. Bacterial cellulose production by Gluconacetobacter hansenii in an agitated culture without living non-cellulose producing cells. Enzyme and Microbial Technology 37(3), 347-354.

Kaewnopparat, S., Sansernluk, K., Faroongsarng, D., 2008. Behavior of freezable bound water in the bacterial cellulose produced by Acetobacter xylinum: An approach using thermoporosimetry. AAPS PharmSciTech 9(2), 701-707.

Kamide, K., Matsuda, Y., lijima, H., Okajima, K., 1990. Effect of culture conditions of acetic acid bacteria on cellulose biosynthesis. British Polymer Journal 22(2), 167-171. 
1079 Kim, J.-S., Reneker, D.H., 1999. Polybenzimidazole nanofiber produced by electrospinning.

1080 Polymer Engineering \& Science 39(5), 849-854.

1081 Kim, J., Cai, Z., Lee, H.S., Choi, G.S., Lee, D.H., Jo, C., 2011. Preparation and characterization of a

1082 Bacterial cellulose/Chitosan composite for potential biomedical application. Journal of Polymer

1083 Research 18(4), 739-744.

1084 Klemm, D., Schumann, D., Udhardt, U., Marsch, S., 2001. Bacterial synthesized cellulose-artificial

1085 blood vessels for microsurgery. Progress in Polymer Science 26(9), 1561-1603.

1086 Kosmider, K., Scott, J., 2002. Polymeric nanofibres exhibit an enhanced air filtration performance.

1087 Filtration \& Separation 39(6), 20-22.

1088 Kouda, T., Yano, H., Yoshinaga, F., 1997. Effect of agitator configuration on bacterial cellulose

1089 productivity in aerated and agitated culture. Journal of Fermentation and Bioengineering 83(4),

1090 371-376.

1091 Kouda, T., Yano, H., Yoshinaga, F., Kaminoyama, M., Kamiwano, M., 1996. Characterization of

1092 non-newtonian behavior during mixing of bacterial cellulose in a bioreactor. Journal of

1093 Fermentation and Bioengineering 82(4), 382-386.

1094 Kouhi, M., Jayarama Reddy, V., Fathi, M., Shamanian, M., Valipouri, A., Ramakrishna, S., 2019.

1095 Poly (3-hydroxybutyrate-co-3-hydroxyvalerate)/fibrinogen/bredigite nanofibrous membranes

1096 and their integration with osteoblasts for guided bone regeneration. Journal of Biomedical

1097 Materials Research Part A 107(6), 1154-1165.

1098 Krystynowicz, A., 1997. Method of bacterial cellulose production, Sposob wytwarzania celulozy

1099 bakteryjnej. Patent PL. World Intellectual Property Organisation Poland.

1100 Krystynowicz, A., Czaja, W., Wiktorowska-Jezierska, A., Gonçalves-Miśkiewicz, M., Turkiewicz, M., 1101 Bielecki, S., 2002. Factors affecting the yield and properties of bacterial cellulose. Journal of 1102 Industrial Microbiology and Biotechnology 29(4), 189-195.

1103 Laçin, N.T., 2014. Development of biodegradable antibacterial cellulose based hydrogel 1104 membranes for wound healing. International Journal of Biological Macromolecules 67, 22-27.

1105 Lamke, L.O., Nilsson, G.E., Reithner, H.L., 1977. The evaporative water loss from burns and the 1106 water-vapour permeability of grafts and artificial membranes used in the treatment of burns. 1107 Burns 3(3), 159-165.

1108 Łaskiewicz, B., 1998. Solubility of bacterial cellulose and its structural properties. Journal of 1109 Applied Polymer Science 67(11), 1871-1876.

1110 Lee, S.E., Park, Y.S., 2017. The role of bacterial cellulose in artificial blood vessels. Molecular \& 1111 Cellular Toxicology 13(3), 257-261.

1112 Li, J., Wan, Y., Li, L., Liang, H., Wang, J., 2009. Preparation and characterization of 2,3-dialdehyde 1113 bacterial cellulose for potential biodegradable tissue engineering scaffolds. Materials Science and 1114 Engineering: C 29(5), 1635-1642.

1115 Lin, S.-B., Hsu, C.-P., Chen, L.-C., Chen, H.-H., 2009. Adding enzymatically modified gelatin to 1116 enhance the rehydration abilities and mechanical properties of bacterial cellulose. Food 1117 Hydrocolloids 23(8), 2195-2203.

1118 Lin, W.-C., Lien, C.-C., Yeh, H.-J., Yu, C.-M., Hsu, S.-h., 2013. Bacterial cellulose and bacterial 1119 cellulose-chitosan membranes for wound dressing applications. Carbohydrate Polymers 94(1), 1120 603-611.

1121 Lu, X., Shen, X., 2011. Solubility of bacteria cellulose in zinc chloride aqueous solutions. 1122 Carbohydrate Polymers 86(1), 239-244.

1123 Luo, C.J., Stoyanov, S.D., Stride, E., Pelan, E., Edirisinghe, M., 2012. Electrospinning versus fibre 1124 production methods: from specifics to technological convergence. Chem Soc Rev 41(13), 470811254735.

1126 Mahalingam, S., Edirisinghe, M., 2013. Forming of polymer nanofibers by a pressurised gyration 1127 process. Macromolecular Rapid Communications 34(14), 1134-1139. 
1128 Marins, J.A., Soares, B.G., Dahmouche, K., Ribeiro, S.J.L., Barud, H., Bonemer, D., 2011. Structure 1129 and properties of conducting bacterial cellulose-polyaniline nanocomposites. Cellulose 18(5), $1130 \quad 1285-1294$.

1131 Martin, P., 1997. Wound healing-aiming for perfect skin regeneration. Science 276(5309), 75.

1132 Martínez-Sanz, M., Olsson, R.T., Lopez-Rubio, A., Lagaron, J.M., 2011. Development of 1133 electrospun EVOH fibres reinforced with bacterial cellulose nanowhiskers. Part I: Characterization 1134 and method optimization. Cellulose 18(2), 335-347.

1135 Mikkelsen, D., Flanagan, B.M., Dykes, G.A., Gidley, M.J., 2009. Influence of different carbon 1136 sources on bacterial cellulose production by Gluconacetobacter xylinus strain ATCC 53524. 1137 Journal of Applied Microbiology 107(2), 576-583.

1138 Mikkelsen, M.D., Harholt, J., Ulvskov, P., Johansen, I.E., Fangel, J.U., Doblin, M.S., Bacic, A., 1139 Willats, W.G., 2014. Evidence for land plant cell wall biosynthetic mechanisms in charophyte 1140 green algae. Annals of Botany 114(6), 1217-1236.

1141 Miyamoto, T., Takahashi, S.-i., Ito, H., Inagaki, H., Noishiki, Y., 1989. Tissue biocompatibility of

1142

1143

1144

1145

1146

1147

1148

1149

1150

1151

1152

1153

1154

1155

1156

1157

1158

1159

1160

1161

1162

1163

1164

1165

1166

1167

1168

1169

1170

1171

1172 cellulose and its derivatives. Journal of Biomedical Materials Research 23(1), 125-133.

Mohd Amin, M.C.I., Ahmad, N., Halib, N., Ahmad, I., 2012. Synthesis and characterization of thermo- and $\mathrm{pH}$-responsive bacterial cellulose/acrylic acid hydrogels for drug delivery. Carbohydrate Polymers 88(2), 465-473.

Monaco, G., Cholas, R., Salvatore, L., Madaghiele, M., Sannino, A., 2017. Sterilization of collagen scaffolds designed for peripheral nerve regeneration: Effect on microstructure, degradation and cellular colonization. Materials Science \& Engineering. C, Materials for Biological Applications 71, 335-344.

Moreira, S., Silva, N.B., Almeida-Lima, J., Rocha, H.A., Medeiros, S.R., Alves, C., Jr., Gama, F.M., 2009. BC nanofibres: in vitro study of genotoxicity and cell proliferation. Toxicol Lett 189(3), 235241.

Morgenstern, B., Berger, W., 1993. Investigations about dissolution of cellulose in the $\mathrm{LiCl} / \mathrm{N}, \mathrm{N}-$ dimethylformamide system. Acta Polymerica 44(2), 100-102.

Nakayama, A., Kakugo, A., Gong, J.P., Osada, Y., Takai, M., Erata, T., Kawano, S., 2004. High mechanical strength double-network hydrogel with bacterial cellulose. Advanced Functional Materials 14(11), 1124-1128.

Naritomi, T., Kouda, T., Yano, H., Yoshinaga, F., 1998a. Effect of ethanol on bacterial cellulose production from fructose in continuous culture. Journal of Fermentation and Bioengineering 85(6), 598-603.

Naritomi, T., Kouda, T., Yano, H., Yoshinaga, F., 1998b. Effect of lactate on bacterial cellulose production from fructose in continuous culture. Journal of Fermentation and Bioengineering 85(1), 89-95.

Nishi, Y., Uryu, M., Yamanaka, S., Watanabe, K., Kitamura, N., Iguchi, M., Mitsuhashi, S., 1990. The structure and mechanical properties of sheets prepared from bacterial cellulose. Journal of Materials Science 25(6), 2997-3001.

Nishino, T., Takano, K., Nakamae, K., 1995. Elastic modulus of the crystalline regions of cellulose polymorphs. Journal of Polymer Science Part B: Polymer Physics 33(11), 1647-1651.

Park, W.-I., Kang, M., Kim, H.-S., Jin, H.-J., 2007. Electrospinning of poly(ethylene oxide) with bacterial cellulose whiskers. Macromolecular Symposia 249-250(1), 289-294.

Peggy O'Neill, S., Cannon, R.E., 2000. Acetobacter xylinum: An inquiry into cellulose biosynthesis. The American Biology Teacher 62(6), 442-444.

1173 Pertile, R.A.N., Andrade, F.K., Alves, C., Gama, M., 2010. Surface modification of bacterial 1174 cellulose by nitrogen-containing plasma for improved interaction with cells. Carbohydrate 1175 Polymers 82(3), 692-698.

1176 Phisalaphong, M., Suwanmajo, T., Sangtherapitikul, P., 2008. Novel nanoporous membranes from 1177 regenerated bacterial cellulose. Journal of Applied Polymer Science 107(1), 292-299. 
Picheth, G.F., Pirich, C.L., Sierakowski, M.R., Woehl, M.A., Sakakibara, C.N., de Souza, C.F., Martin, A.A., da Silva, R., de Freitas, R.A., 2017. Bacterial cellulose in biomedical applications: A review. International Journal of Biological Macromolecules 104, 97-106.

Pommet, M., Juntaro, J., Heng, J.Y.Y., Mantalaris, A., Lee, A.F., Wilson, K., Kalinka, G., Shaffer, M.S.P., Bismarck, A., 2008. Surface modification of natural fibers using bacteria: depositing bacterial cellulose onto natural fibers to create hierarchical fiber reinforced nanocomposites. Biomacromolecules 9(6), 1643-1651.

Portela, R., Leal, C.R., Almeida, P.L., Sobral, R.G., 2019. Bacterial cellulose: a versatile biopolymer for wound dressing applications. Microbial Biotechnology 12(4), 586-610.

Posnett, J., Gottrup, F., Lundgren, H., Saal, G., 2009. The resource impact of wounds on healthcare providers in Europe. Journal of Wound Care 18(4), 154-161.

Qin, Z., Ji, L., Yin, X., Zhu, L., Lin, Q., Qin, J., 2014. Synthesis and characterization of bacterial cellulose sulfates using a SO3/pyridine complex in DMAc/LiCl. Carbohydrate Polymers 101(Supplement C), 947-953.

R. Chawla, P., Bajaj, I., Survase, S., S. Singhal, R., 2009. Microbial cellulose: fermentative production and applications. Food Technology and Biotechnology 47(2):107-124.

Rangaswamy, B.E., Vanitha, K.P., Hungund, B.S., 2015. Microbial cellulose production from bacteria isolated from rotten fruit. International Journal of Polymer Science 2015, 8.

Ring, D.F., Nashed, W., Dow, T., 1986a. Liquid loaded pad for medical applications. Johnson \& Johnson Patient Care Inc.

Ring, D.F., Nashed, W., Dow, T., 1986b. Microbial polysaccharide articles and methods of production. Johnson \& Johnson Products Inc. .

Rodan, S.B., Imai, Y., Thiede, M.A., Wesolowski, G., Thompson, D., Bar-Shavit, Z., Shull, S., Mann, K., Rodan, G.A., 1987. Characterization of a human osteosarcoma cell line (Saos-2) with osteoblastic properties. Cancer Research 47(18), 4961-4966.

Rohrling, J., Potthast, A., Rosenau, T., Lange, T., Borgards, A., Sixta, H., Kosma, P., 2002. A novel method for the determination of carbonyl groups in cellulosics by fluorescence labeling. 2 . Validation and applications. Biomacromolecules 3(5), 969-975.

Ross, P., Mayer, R., Benziman, M., 1991. Cellulose biosynthesis and function in bacteria. Microbiological Reviews 55(1), 35-58.

Ross, P., Mayer, R., Weinhouse, H., Amikam, D., Huggirat, Y., Benziman, M., de Vroom, E., Fidder, A., de Paus, P., Sliedregt, L.A., 1990. The cyclic diguanylic acid regulatory system of cellulose synthesis in Acetobacter xylinum. Chemical synthesis and biological activity of cyclic nucleotide dimer, trimer, and phosphothioate derivatives. Journal of Biological Chemistry 265(31), 1893318943.

Sachlos, E., Czernuszka, J.T., 2003. Making tissue engineering scaffolds work. Review: the application of solid freeform fabrication technology to the production of tissue engineering scaffolds. European Cells \& Materials 5, 29-39; discussion 39-40.

Schlufter, K., Schmauder, H.-P., Dorn, S., Heinze, T., 2006. Efficient homogeneous chemical modification of bacterial cellulose in the ionic liquid 1-N-butyl-3-methylimidazolium chloride. Macromolecular Rapid Communications 27(19), 1670-1676.

Schramm, M., Hestrin, S., 1954. Factors affecting production of cellulose at the air/liquid interface of a culture of Acetobacter xylinum. J Gen Microbiol 11(1), 123-129.

Schrecker, S.T., Gostomski, P.A., 2005. Determining the water holding capacity of microbial cellulose. Biotechnology Letters 27(19), 1435-1438.

Shen, X., Ji, Y., Wang, D., Yang, Q., 2010. Solubility of a high molecular-weight bacterial cellulose in lithium chloride/N,N-dimethylacetamide solution. Journal of Macromolecular Science, Part B Physics 49(5), 1012-1018.

Shezad, O., Khan, S., Khan, T., Park, J.K., 2010. Physicochemical and mechanical characterization of bacterial cellulose produced with an excellent productivity in static conditions using a simple fed-batch cultivation strategy. Carbohydrate Polymers 82(1), 173-180. 
Shibazaki, H., Kuga, S., Onabe, F., Usuda, M., 1993. Bacterial cellulose membrane as separation medium. Journal of Applied Polymer Science 50(6), 965-969.

Shoda, M., Sugano, Y., 2005. Recent advances in bacterial cellulose production. Biotechnology and Bioprocess Engineering 10(1), 1.

Sofokleous, P., Stride, E., Bonfield, W., Edirisinghe, M., 2013. Design, construction and performance of a portable handheld electrohydrodynamic multi-needle spray gun for biomedical applications. Materials Science and Engineering: C 33(1), 213-223.

Song, H.-J., Li, H., Seo, J.-H., Kim, M.-J., Kim, S.-J., 2009. Pilot-scale production of bacterial cellulose by a spherical type bubble column bioreactor using saccharified food wastes. Korean Journal of Chemical Engineering 26(1), 141-146.

Stock, U.A., Vacanti, J.P., 2001. Tissue engineering: Current state and prospects. Annual Review of Medicine 52(1), 443-451.

Sulaeva, I., Henniges, U., Rosenau, T., Potthast, A., 2015. Bacterial cellulose as a material for wound treatment: Properties and modifications. A review. Biotechnology Advances 33(8), 15471571.

Svensson, A., Nicklasson, E., Harrah, T., Panilaitis, B., Kaplan, D.L., Brittberg, M., Gatenholm, P., 2005. Bacterial cellulose as a potential scaffold for tissue engineering of cartilage. Biomaterials 26(4), 419-431.

Thomas, S., 2008. A review of the physical, biological and clinical properties of a bacterial cellulose wound. Journal of Wound Care 17(8), 349-352.

Torres, G.F., Commeaux, S., Troncoso, P.O., 2012. Biocompatibility of bacterial cellulose based biomaterials. Journal of Functional Biomaterials 3(4).

Tsuchida, T., Yoshinaga, F., 1997. Production of bacterial cellulose by agitation culture systems. Pure and Applied Chemistry. p. 2453.

UI-Islam, M., Khan, T., Park, J.K., 2012. Water holding and release properties of bacterial cellulose obtained by in situ and ex situ modification. Carbohydrate Polymers 88(2), 596-603.

United, S., Congress, 1993. Biopolymers : making materials nature's way. U.S Congress, Washington, DC.

van de Witte, P., Esselbrugge, H., Peters, A.M.P., Dijkstra, P.J., Feijen, J., Groenewegen, R.J.J., Smid, J., Olijslager, J., Schakenraad, J.M., Eenink, M.J.D., Sam, A.P., 1993. Formation of porous membranes for drug delivery systems. Journal of Controlled Release 24(1), 61-78.

Vandamme, E.J., De Baets, S., Vanbaelen, A., Joris, K., De Wulf, P., 1998. Improved production of bacterial cellulose and its application potential. Polymer Degradation and Stability 59(1), 93-99. VanderHart, D.L., Atalla, R.H., 1984. Studies of microstructure in native celluloses using solid-state carbon-13 NMR. Macromolecules 17(8), 1465-1472.

Wan, Y.Z., Luo, H., He, F., Liang, H., Huang, Y., Li, X.L., 2009. Mechanical, moisture absorption, and biodegradation behaviours of bacterial cellulose fibre-reinforced starch biocomposites. Composites Science and Technology 69(7), 1212-1217.

Wang, J., Tavakoli, J., Tang, Y., 2019. Bacterial cellulose production, properties and applications with different culture methods - A review. Carbohydrate Polymers 219, 63-76.

Wang, Y., Wang, G., Luo, X., Qiu, J., Tang, C., 2012. Substrate stiffness regulates the proliferation, migration, and differentiation of epidermal cells. Burns 38(3), 414-420.

Watanabe, K., Tabuchi, M., Morinaga, Y., Yoshinaga, F., 1998. Structural features and properties of bacterial cellulose produced in agitated culture. Cellulose 5(3), 187-200.

Weinhouse, H., Benziman, M., 1974. Regulation of hexose phosphate metabolism in Acetobacter xylinum. Biochem J 138(3), 537-542.

Wu, J., Zheng, Y., Yang, Z., Lin, Q., Qiao, K., Chen, X., Peng, Y., 2014. Influence of dialdehyde bacterial cellulose with the nonlinear elasticity and topology structure of ECM on cell adhesion and proliferation. RSC Advances 4(8), 3998-4009.

Xu, R., Xia, H., He, W., Li, Z., Zhao, J., Liu, B., Wang, Y., Lei, Q., Kong, Y., Bai, Y., Yao, Z., Yan, R., Li, H., Zhan, R., Yang, S., Luo, G., Wu, J., 2016. Controlled water vapor transmission rate promotes 
wound-healing via wound re-epithelialization and contraction enhancement. Scientific Reports 6 ,

128124596.

1282 Yamamoto, H., Horii, F., 1993. CPMAS carbon-13 NMR analysis of the crystal transformation 1283 induced for Valonia cellulose by annealing at high temperatures. Macromolecules 26(6), 131312841317.

1285 Yamanaka, S., Sugiyama, J., 2000. Structural modification of bacterial cellulose. Cellulose 7(3), 1286 213-225

1287 Yamanaka, S., Watanabe, K., Kitamura, N., Iguchi, M., Mitsuhashi, S., Nishi, Y., Uryu, M., 1989.

1288 The structure and mechanical properties of sheets prepared from bacterial cellulose. Journal of 1289 Materials Science 24(9), 3141-3145.

1290 Yan, Z., Chen, S., Wang, H., Wang, B., Jiang, J., 2008. Biosynthesis of bacterial cellulose/multi1291 walled carbon nanotubes in agitated culture. Carbohydrate Polymers 74(3), 659-665.

1292 Yano, H., Sugiyama, J., Nakagaito, A., Nogi, M., Matsuura, T., Hikita, M., Handa, K., 2005. Optically 1293 transparent composites reinforced with networks of bacterial nanofibers. Advanced Materials 1294 17(2), 153-155.

1295 Yano, S., Maeda, H., Nakajima, M., Hagiwara, T., Sawaguchi, T., 2008. Preparation and mechanical 1296 properties of bacterial cellulose nanocomposites loaded with silica nanoparticles. Cellulose 15(1), 111-120.

1298 Yarin, A.L., Kataphinan, W., Reneker, D.H., 2005. Branching in electrospinning of nanofibers. 1299 Journal of Applied Physics 98(6), 064501.

1300 Yoshinaga, F., Tonouchi, N., Watanabe, K., 1997. Research progress in production of bacterial 1301 cellulose by aeration and agitation culture and its application as a new industrial material. 1302 Bioscience, Biotechnology, and Biochemistry 61(2), 219-224.

1303 Young, R.J., Lu, D., Day, R.J., Knoff, W.F., Davis, H.A., 1992. Relationship between structure and 1304 mechanical properties for aramid fibres. Journal of Materials Science 27(20), 5431-5440.

1305 Yuyang, L., Xianqiong, C., Xin, J.H., 2006. Super-hydrophobic surfaces from a simple coating 1306 method: a bionic nanoengineering approach. Nanotechnology 17(13), 3259.

1307 Zaar, K., 1977. The biogenesis of cellulose by Acetobacter xylinum. Cytobiologie 16, 1-15.

1308 Zaar, K., 1979. Visualization of pores (export sites) correlated with cellulose production in the 1309 envelope of the gram-negative bacterium Acetobacter xylinum. J Cell Biol 80(3), 773-777.

1310 Zhang, C., Shao, Y., Zhu, L., Wang, J., Wang, J., Guo, Y., 2017. Acute toxicity, biochemical toxicity 1311 and genotoxicity caused by 1-butyl-3-methylimidazolium chloride and 1-butyl-31312 methylimidazolium tetrafluoroborate in zebrafish (Danio rerio) livers. Environmental Toxicology 1313 and Pharmacology 51, 131-137. 

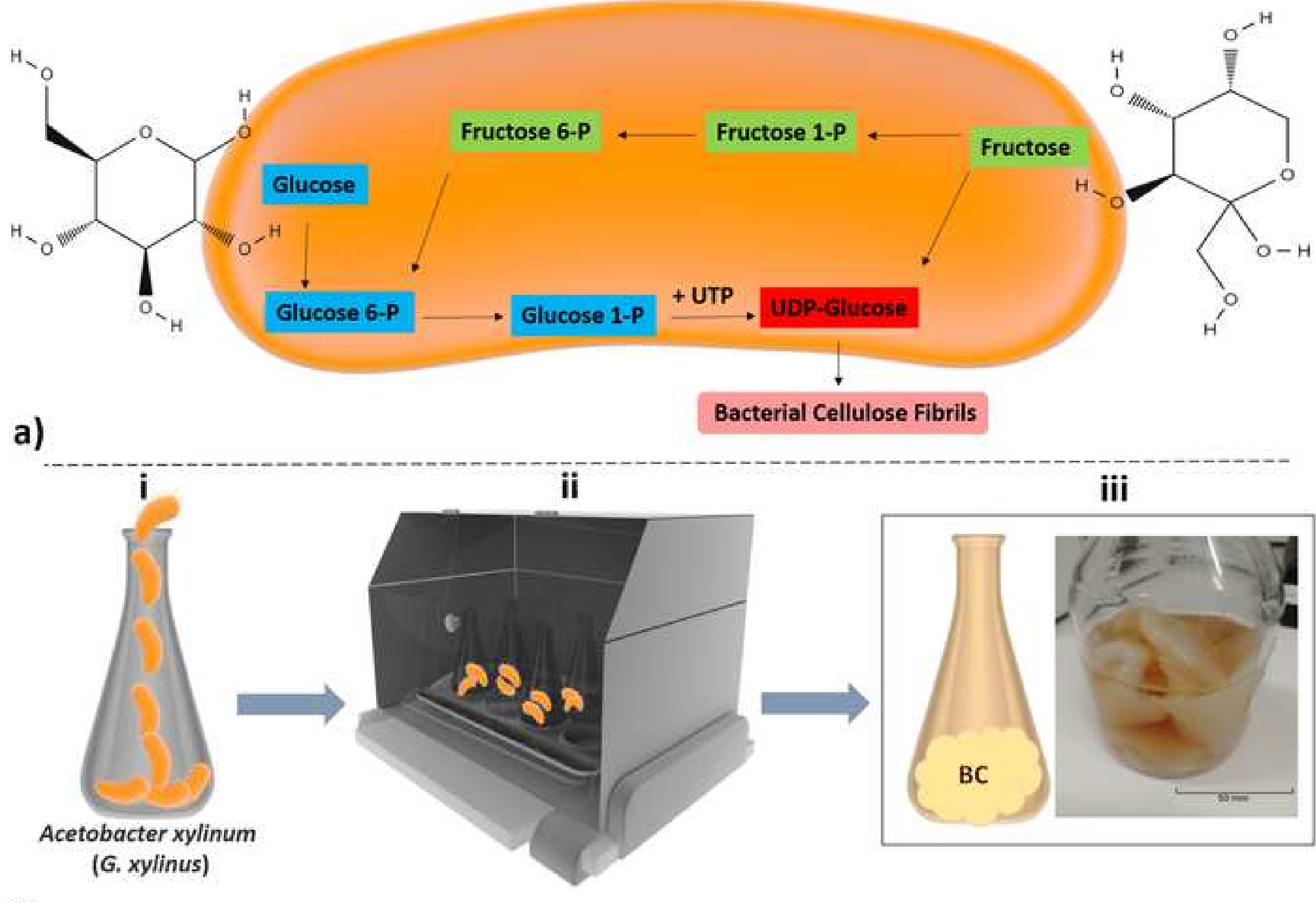

iii

b) 

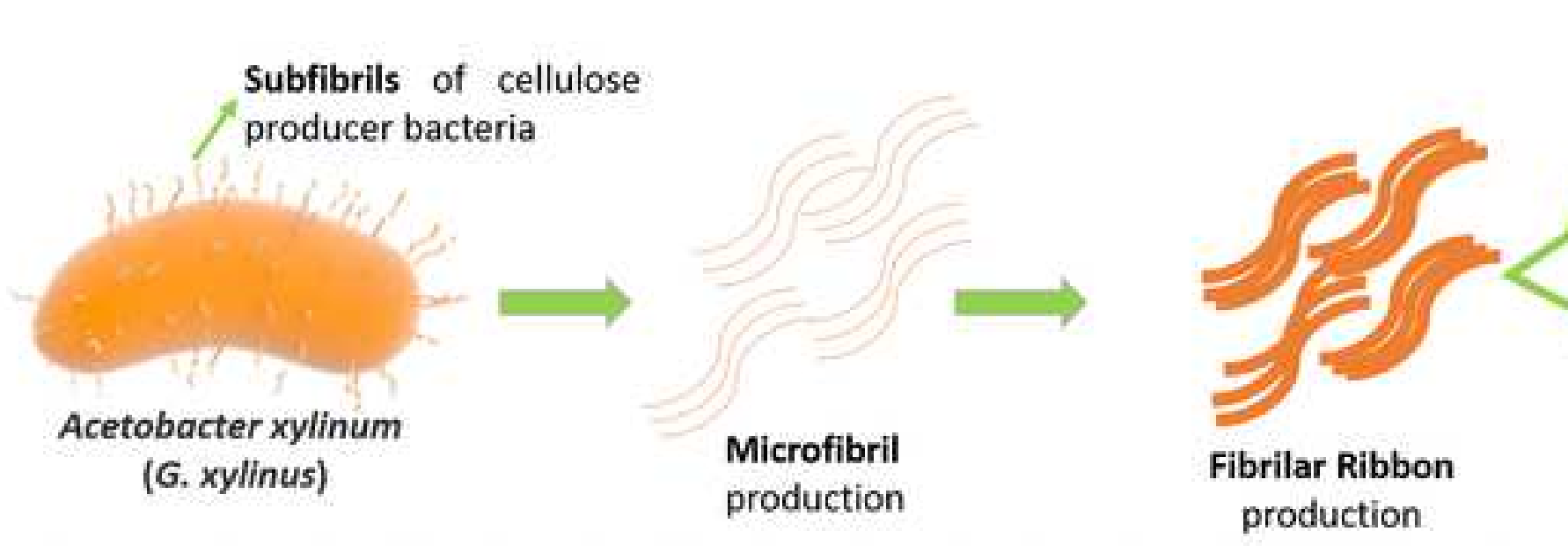

Side view of ribbons
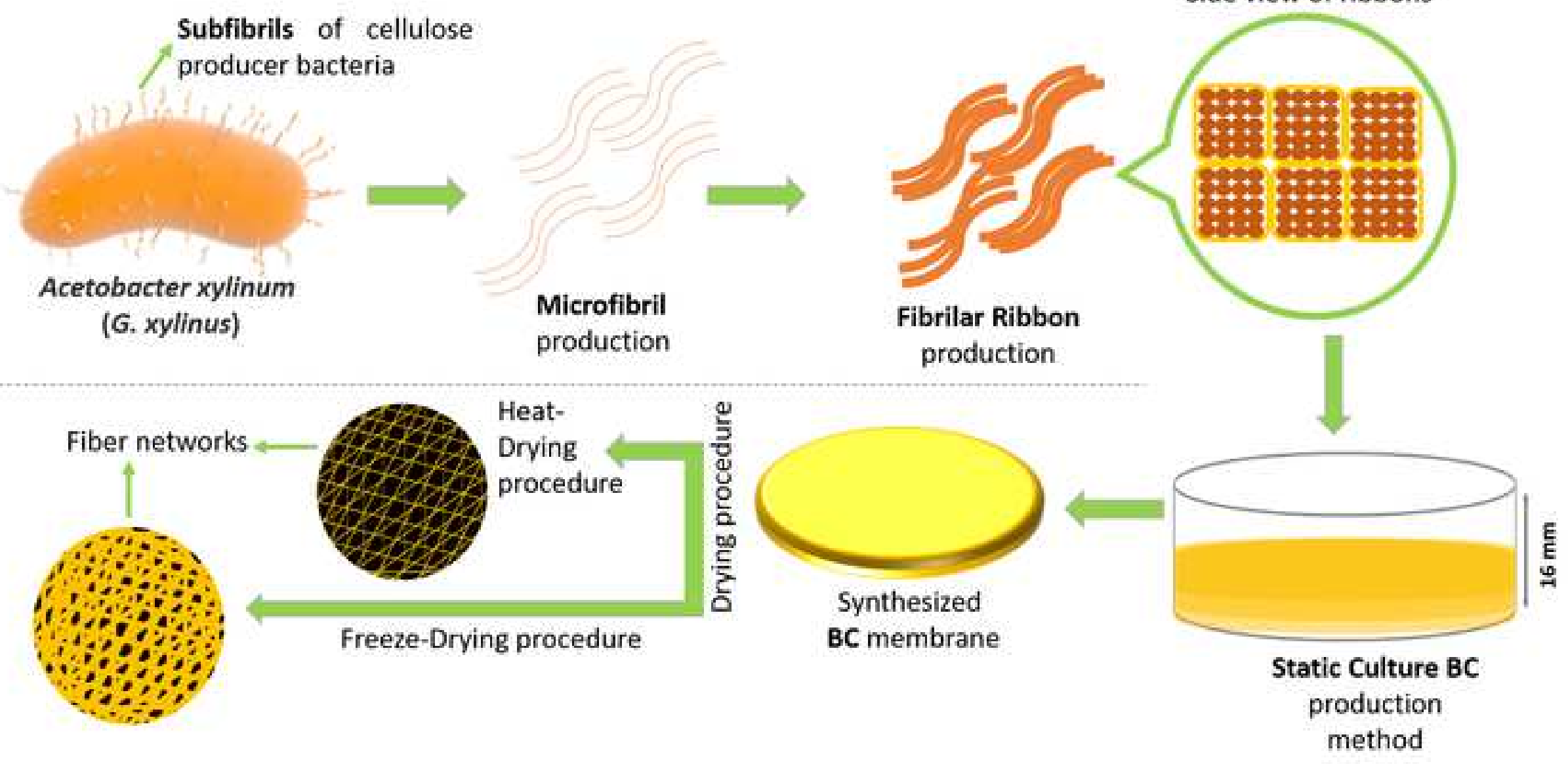


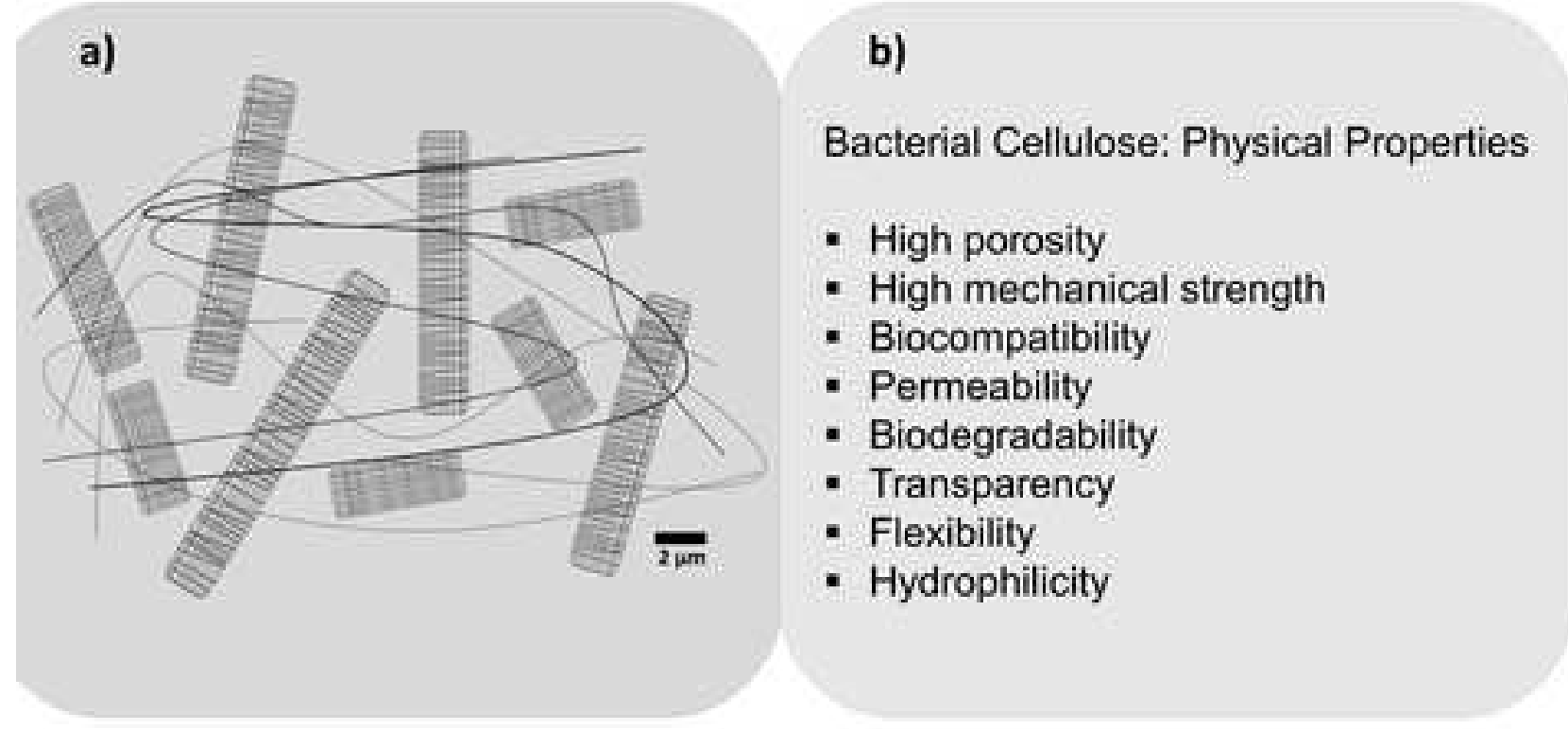

c)

Bacterial Cellulose: Biomedical Applications

- Skin (wound dressing)

$\checkmark$ Cartlidge

- Cornea

- Bone

U Urethra

- Blood vessels

- Contact lenses

- Drug delivery systems

- Bio sensors 


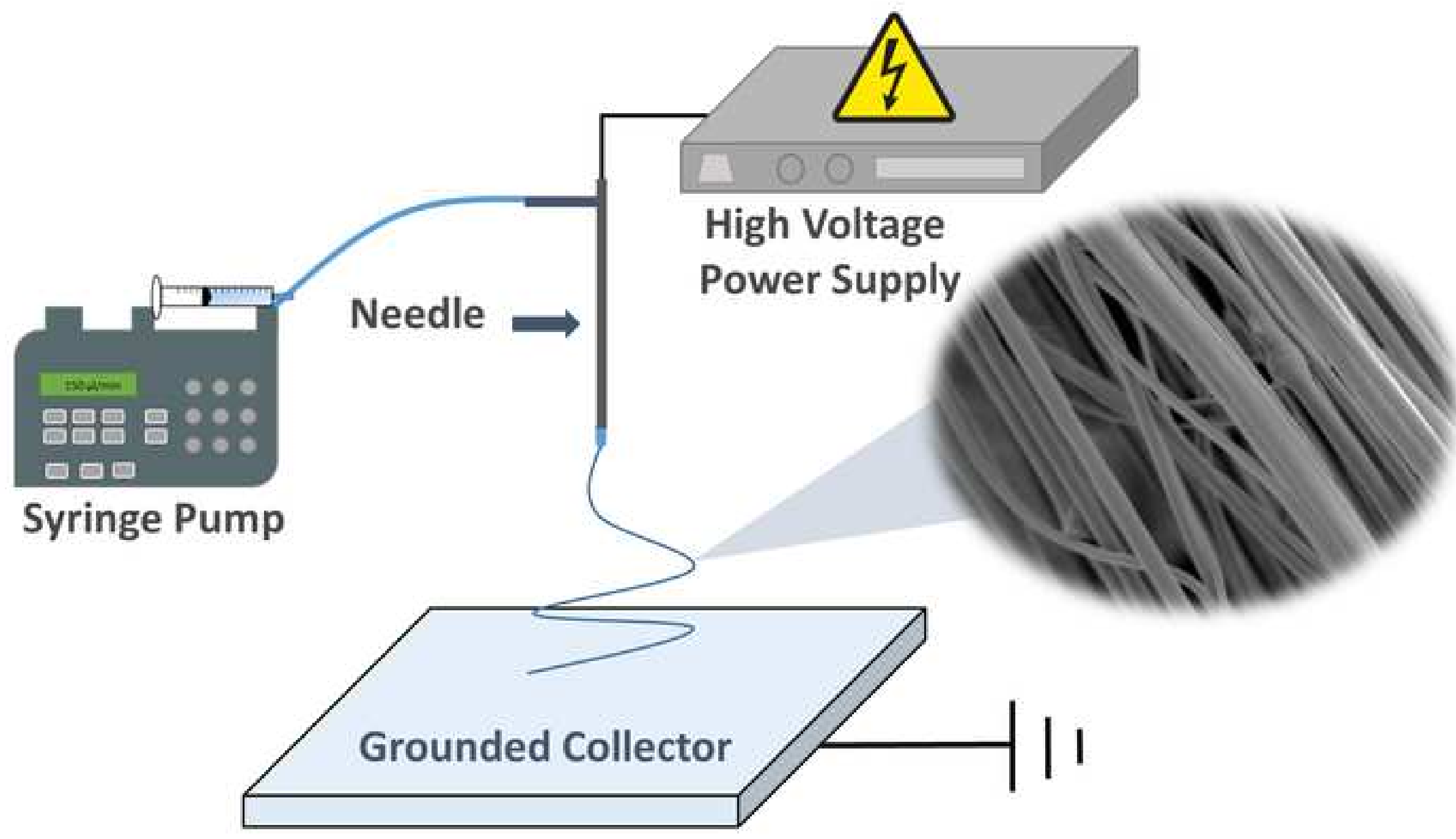



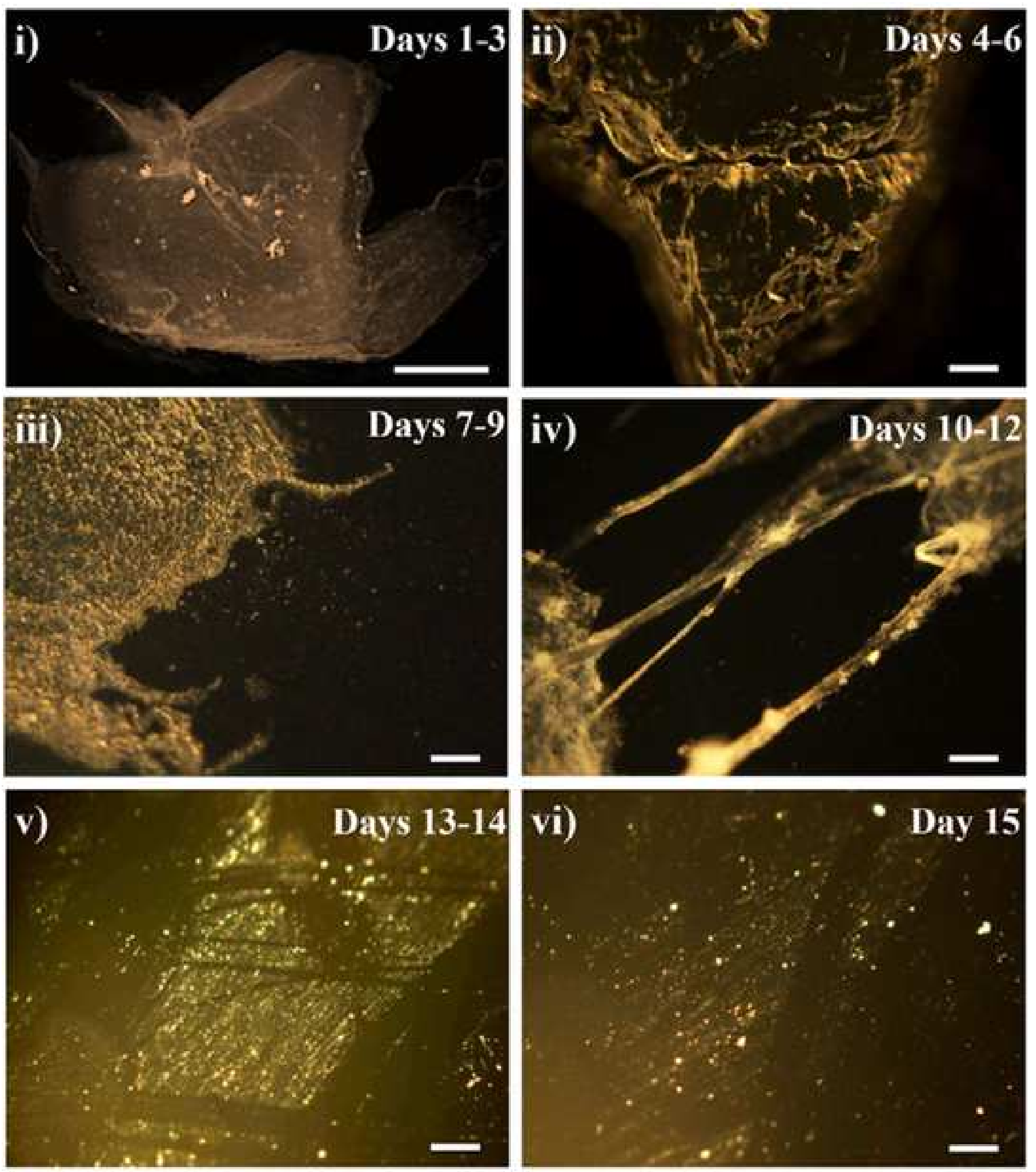


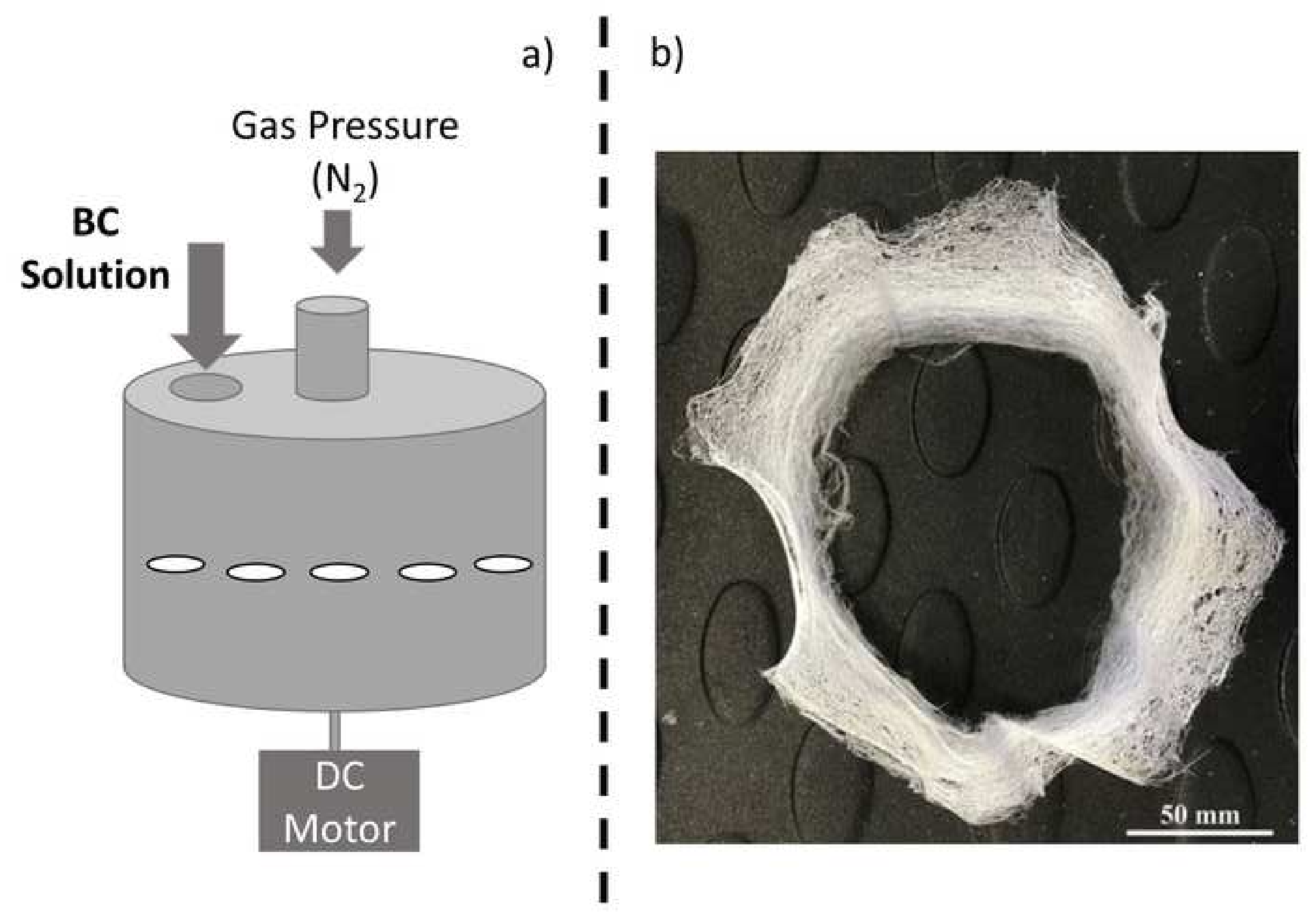



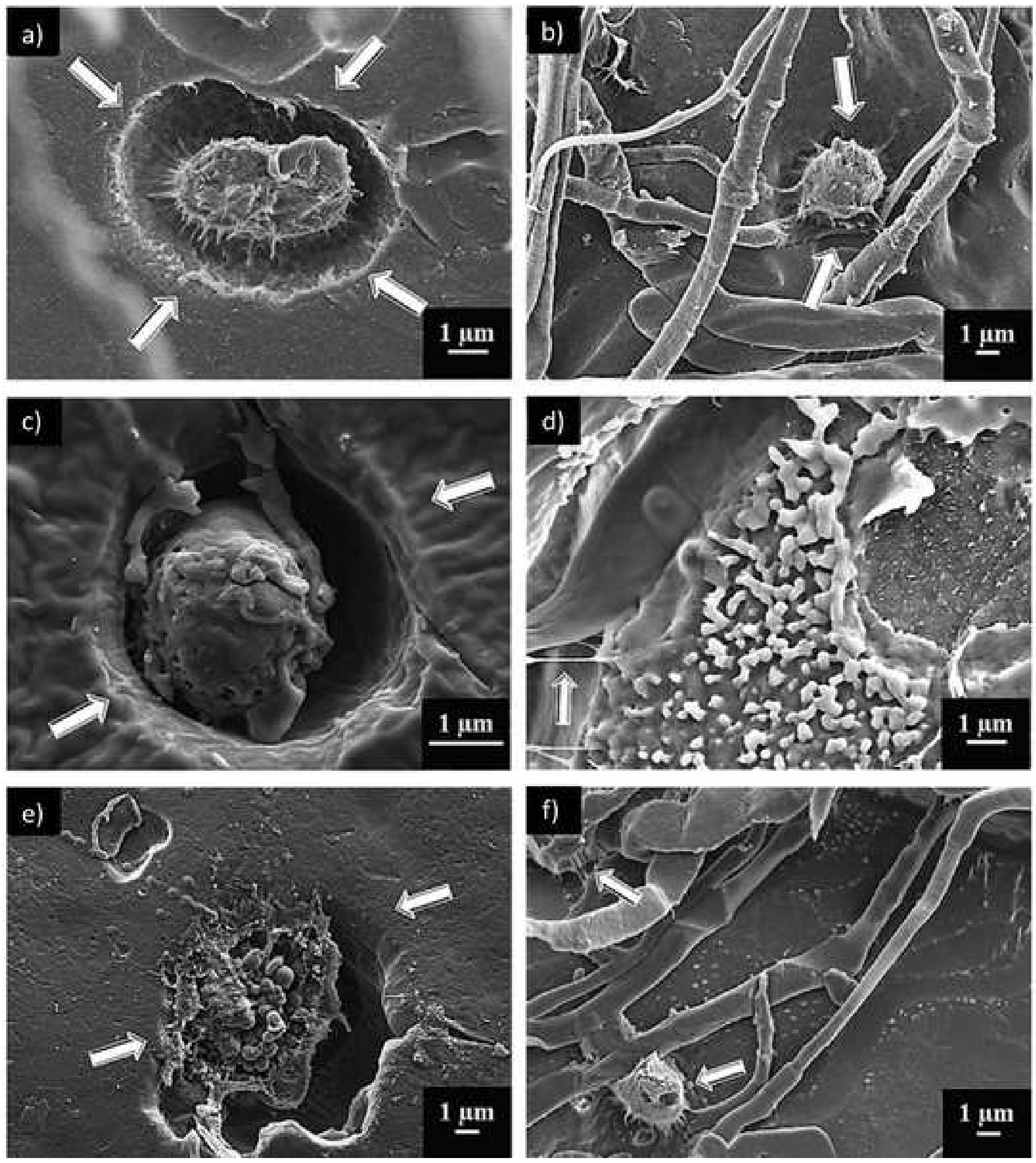
Table 1: Table summarising the key properties of $\mathrm{BC}$ and its relevance to wound healing.

\begin{tabular}{|c|c|c|c|}
\hline Property & Advantage & $\begin{array}{l}\text { Benefits to Wound } \\
\text { Healing }\end{array}$ & References \\
\hline Biodegradability & $\begin{array}{l}\text { Bandage for } \\
\text { chronic wounds } \\
\text { potentially } \\
\text { doesn't need } \\
\text { removing }\end{array}$ & $\begin{array}{l}\text { Reduction of pain from } \\
\text { bandage removal }\end{array}$ & $\begin{array}{l}\text { (Hu and Catchmark, } \\
\text { 2011; Laçin, 2014) }\end{array}$ \\
\hline $\begin{array}{l}\text { ECM } \\
\text { Resembling } \\
\text { Matrix }\end{array}$ & $\begin{array}{l}\text { Biomimetic } \\
\text { structure } \\
\text { promotes prompt } \\
\text { wound healing }\end{array}$ & $\begin{array}{l}\text { Cells of the wound } \\
\text { response can be guided } \\
\text { to become more efficient }\end{array}$ & $\begin{array}{l}\text { (Svensson et al., } \\
\text { 2005; Wu et al., 2014) }\end{array}$ \\
\hline $\begin{array}{l}\text { Excellent } \\
\text { Biocompatibility }\end{array}$ & $\begin{array}{l}\text { Reduces } \\
\text { complications } \\
\text { with immune } \\
\text { rejection }\end{array}$ & $\begin{array}{l}\text { Risk of fibrotic scarring } \\
\text { is lower }\end{array}$ & $\begin{array}{l}\text { (Helenius et al., 2006; } \\
\text { Torres et al., 2012) }\end{array}$ \\
\hline High Stiffness & Great Durability & $\begin{array}{l}\text { Allows bandage to } \\
\text { withstand some trauma }\end{array}$ & $\begin{array}{l}\text { (Lin et al., 2013; } \\
\text { Nakayama et al., } \\
\text { 2004) }\end{array}$ \\
\hline $\begin{array}{l}\text { High Tensile } \\
\text { Strength }\end{array}$ & $\begin{array}{l}\text { Resistance } \\
\text { against tearing } \\
\text { as a wound } \\
\text { dressing }\end{array}$ & $\begin{array}{l}\text { Provides mechanical } \\
\text { protection against } \\
\text { external trauma }\end{array}$ & $\begin{array}{l}\text { (Naritomi et al., } \\
\text { 1998b; Wan et al., } \\
\text { 2009) }\end{array}$ \\
\hline $\begin{array}{l}\text { High Water } \\
\text { Uptake Ability }\end{array}$ & $\begin{array}{l}\text { Maintains moist } \\
\text { environment and } \\
\text { flow of wound } \\
\text { exudate }\end{array}$ & $\begin{array}{l}\text { Allows for a more } \\
\text { efficient recovery } \\
\text { process and } \\
\text { management of osmotic } \\
\text { environment of cells }\end{array}$ & $\begin{array}{l}\text { (Lin et al., 2009; } \\
\text { Schrecker and } \\
\text { Gostomski, 2005; Ul- } \\
\text { Islam et al., 2012) }\end{array}$ \\
\hline $\begin{array}{l}\text { Large Surface } \\
\text { Area }\end{array}$ & $\begin{array}{l}\text { Increased } \\
\text { interactions with } \\
\text { cells in the } \\
\text { wound response }\end{array}$ & $\begin{array}{l}\text { More efficient cellular } \\
\text { interactions leading to a } \\
\text { healthier recovery }\end{array}$ & $\begin{array}{l}\text { (Iguchi et al., 2000; } \\
\text { Nishi et al., 1990) }\end{array}$ \\
\hline
\end{tabular}

